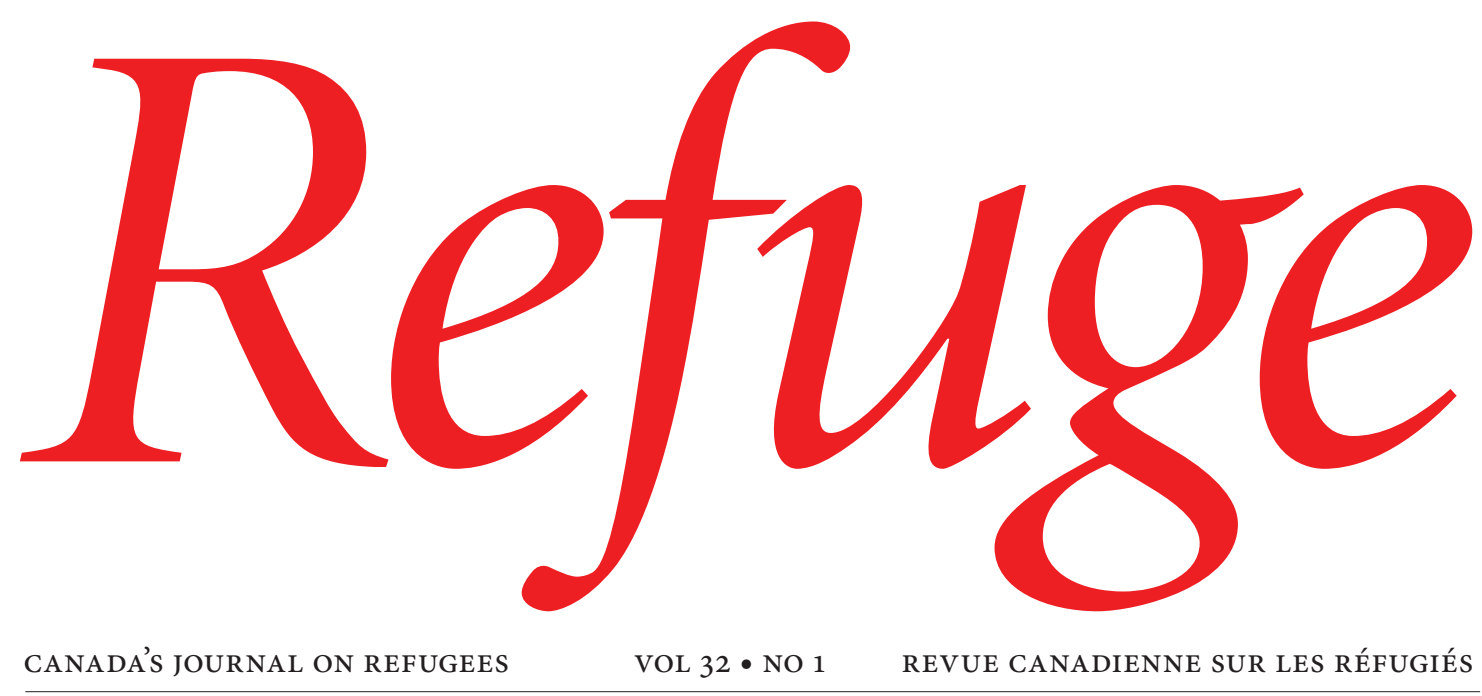

Refugee Voices: Exploring the Border Zones between States and State Bureaucracies DAWN CHATTY

\title{
Displacements of Memory
}

PHILIP MARFLEET

Human Rights and Refugee Protest against Immigration Detention: Refugees' Struggle for Recognition as Human

LUCY FISKE

Narrating "Home": Experiences of German Expellees after the Second World War VANESSA HUGHES

Between Law and the Nation State: Novel Representations of the Refugee SIMON BEHRMAN

"We raise up the voice of the voiceless": Voice, Rights, and Resistance amongst Congolese Human Rights Defenders in Uganda

KATIE R.V. MCQUAID

"Refugee Voices," New Social Media, and Politics of Representation:

Young Congolese in the Diaspora and Beyond

MARIE GODIN AND GIORGIA DONÁ

How Kanere Free Press Resists Biopower

MICHELE C. DERAMO 


\title{
Refuge
}

\section{Canada's Journal on Refugees \\ Revue canadienne sur les réfugiés}

Vol. 32, No. 1

\author{
Centre for Refugee Studies, Room 844, Kaneff Tower, York University \\ 4700 Keele Street, Toronto, Ontario, Canada M3J 1P3 \\ E-mail: refuge@yorku.ca \\ Website: http://www.yorku.ca/refuge
}

\author{
Editor-in-Chief \\ Christina Clark-Kazak \\ Guest Editor Dawn Chatty \\ Managing Editor Johanna Reynolds \\ Book Review Editor Dianna Shandy \\ Editorial Advisory Board \\ Sharryn Aiken, Queen's University \\ Laura Bisaillon, University of Toronto Scarborough \\ Megan Bradley, McGill University \\ François Crépeau, McGill University \\ Jeff Crisp, Refugees International \\ Judith Kumin, University of New Hampshire, Manchester \\ Susan McGrath, York University \\ Volker Türk, UNHCR \\ Madine Vanderplaat, Saint Mary's University
}

Founded in 1981, Refuge is an interdisciplinary journal published by the Centre for Refugee Studies, York University. The journal aims to provide a forum for discussion and critical reflection on refugee and forced migration issues.

Refuge invites contributions from researchers, practitioners, and policy makers with national, international, or comparative perspectives. Special, thematic issues address the broad scope of the journal's mandate, featuring articles and reports, shorter commentaries, and book reviews. All submissions to Refuge are subject to double-blinded peer review. Articles are accepted in either English or French.

Refuge is a non-profit, independent periodical funded by the Social Sciences and Humanities Research Council of Canada and supported by the membership of the Canadian Association for Refugee Studies (CARFMs). The views expressed in Refuge do not necessarily reflect those of its funders or editors.

Refuge is indexed and abstracted in the Index to Canadian Legal Literature, Pais International, Sociological Abstracts, the International Bibliography of the Social Sciences, and Canadian Business and Current Affairs. In accordance with the journal's open access policy, the full text of articles published in Refuge is also available online through our website, www.yorku.ca/refuge.

ISSN (online): 1920-7336 


\section{Contents}

\section{INTRODUCTION}

Refugee Voices: Exploring the Border Zones between

States and State Bureaucracies

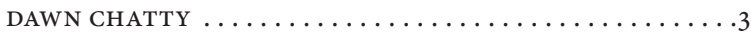

\section{Articles}

Displacements of Memory

PHILIP MARFLEET. . . . . . . . . . . . . . . . . . . .

Human Rights and Refugee Protest against

Immigration Detention: Refugees' Struggles for

Recognition as Human

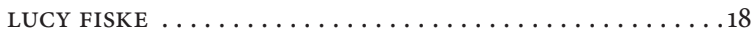

Narrating "Home": Experiences of German Expellees after the Second World War

VANESSA HUGHES

Between Law and the Nation State:

Novel Representations of the Refugee

SIMON BEHRMAN . ............................ 38

"We raise up the voice of the voiceless":

Voice, Rights, and Resistance amongst Congolese

Human Rights Defenders in Uganda

KATIE R.V. MCQUAID. . . . . . . . . . . . . . . . .50

"Refugee Voices," New Social Media, and

Politics of Representation: Young Congolese in the

Diaspora and Beyond

MARIE GODIN

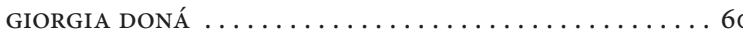

How Kanere Free Press Resists Biopower

MICHELE C. DERAMO ......................72

\section{Book Reviews}

Postcolonial Life Narratives: Testimonial Transactions by Gillian Whitlock

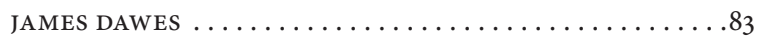

Refugees of the Revolution:

Experiences of Palestinian Exile

by Diana Allan

HELEN TAYLOR . . . . . . . . . . . . . . . . . . . . 84

The Agendas of Tibetan Refugees:

Survival Strategies of a Government-in-Exile

in a World of Transnational Organizations

by Thomas Kauffman

TENZIN WANGMO AND TENZIN SHERAB $\ldots \ldots \ldots \ldots . . .86$

Forced Migration, Reconciliation and Justice

edited by Megan Bradley

IDIL ATAK.

Creating New Futures: Settling Children and

Youth from Refugee Backgrounds

edited by Mary Crock

JULIA MEREDITH HESS. . 


\title{
INTRODUCTION
}

\section{Refugee Voices: Exploring the Border Zones between States and State Bureaucracies}

\author{
DAWN CHATTY
}

\section{Introduction}

$\Theta_{b}$ ettled people have been forced to move and nomads have been coerced into settling for as long as there has been history. Until the emergence of the Westphal concept of the nation (where the state corresponded to the nation, groups of people united by language and culture), movement and mobility were largely recognized and accommodated. However, most contemporary academic disciplines as well as public institutions adopt a particular sedentist perspective on the nation-state. It is commonly recognized that people are displaced and move when political states collapse; they return when political security is restored. The liminal "state" outside the defined territory of the nation-state, where the displaced are found, is regarded as a threat to the world order. ${ }^{1}$ Predominant theory has been that people must be tied to territory, and thus the durable policy solutions advanced are frequently about resettlement. Reality does not support either current forced migration theory or humanitarian aid practices, however, and an epistemological change in thinking about forced migrants is urgently required. This means looking beyond the nationstate-the purview of most academic work in this areaand beyond traditional barriers between disciplines, to give cross-disciplinary attention to the self-expressions and experiences of forced migrants. Furthermore, the forced migrant creates a dilemma in how aesthetic expression is displayed, as their forms of expression cannot be squarely identified with one state or another. The dispossessed and displaced are changed by their experiences in the grey zones between states, and their migrations cannot be neatly catalogued as belonging to one state or culture.

The voices of forced migrants, exiles, and refugees are rarely heard in this context, except to reinforce their passivity, vulnerability, and "neediness" as humanitarian aid recipients in an undefined space between nation-states. The articles in this special issue examine and explore the voices and aesthetic expressions of the displaced and dispossessed as a means of understanding the effects of displacement in terms other than those of the nation-state. They set out to recognize and investigate the frequently silenced voices of forced migrants who exhibit adaptability, resilience, longing, and resistance in the grey zones and borderlands between states and state bureaucracies. We hope to move beyond the term resettlement, in the state of origin, the state of current emplacement, or a third nation-state, in which durable solutions to displacement are conventionally cast, and to examine the experience of displaced groups whose social reality conflicts with the sedentist assumptions on which the nation-state is based.

Jacques Maquet long ago suggested that aesthetic expression is what makes us human, ${ }^{2}$ both reflecting and shaping our social selves. However, the complex implications of Maquet's insight have often been overlooked in the study of forced migration, as even those voices of refugees, exiles, and forced migrants that have been sought by aid agencies and scholars often have been used exclusively in terms of passivity and vulnerability. Rarely has scholarship with the displaced explored the aesthetic expression of other experiences and responses to forced migration. These articles seek 
to redress this oversight by examining forms of resilience and resistance among those marginalized by the nationstate as more than social and economic realities

Aesthetics has a strong significance for human social organization: by referencing shared experience, aesthetics defines an ideational community when it is expressed and perceived, as Maquet has argued. 3 Aesthetic perception and contemplation can thus be political, and aesthetics may possess "relations of correspondence" to other conceptual categories such as kinship and ethnic authenticity. ${ }^{4}$ The relationship between aesthetics and politics has also been addressed by Gell in his discussion of art as a "technology" embodying complex human intentions, ${ }^{5}$ such as the political motivations behind a Yemeni oral poet's performance. ${ }^{6}$ Traditional oral media in the Middle East are an example of Gell's "technology of enchantment," as orality's "enchantment” establishes relations of social power by conferring associations of morality and legitimacy.

Some work among humanitarian aid practitioners and advocates strives to give voice to refugees and forced migrants through storytelling, such as the Hakawati Project for refugees from Syria in Amman, Jordan, in 2014, and through calligraphy, a good example of which is the Silent University project at the Tate Modern Museum in 2014. Participatory photography is also becoming more widely used by aid practitioners as a medium for self-expression of these "silenced" displaced groups of people. But the aesthetic expression of refugees and other forced migrants has largely been silenced by the state-centric humanitarian aid regime.

In March 2014, the Refugee Studies Centre at the University of Oxford held a conference to explore refugee "aesthetic expression." It was the first time that an academic institution focused on the refugees themselves as producers of knowledge rather than as subjects of inquiry. Some of the questions around which the conference was organized included: Under what circumstances do refugees, exiles, and forced migrants leave a nation-state that is collapsing? How do they cope with existence outside the nation-state? How are resilience and resistance to the "bare life" of the refugee and exile expressed across different refugee experiences? What mechanisms and mediums are used to express loss, perseverance, and hope? How do they perceive their futures and manipulate systems outside the nation-state to achieve their goals of dignity, justice, and freedom (i.e., well-being)? How does cultural expression (e.g., aesthetic expression through art, music, literature, and storytelling) contextualize our understanding of refugee experiences? What are common refugee socio-legal and political expressions (e.g., refugees' preferences not to be put in camps [Syria]), or their preferences for durable solutions (e.g., when should repatriation happen for refugees from Burma)? What are the meanings of voice (e.g., the need not only for articulation but also for dialogue/conversation; the difference between having voice and being heard-soliciting refugees' voices is one dimension, but genuinely listening to what those voices say is a much deeper phenomenological process)?

A call for papers resulted with more than 250 submissions, suggesting that a very rich area of interest had been tapped. From these submissions thirty abstracts were selected for development into presentations at the two-day conference. From these excellent presentations, seven were selected for their coherence to form a special issue of the journal Refuge. The authors of these articles span the social sciences and humanities, and each is involved in giving voice to refugees though scholarly publications, print media, and other aesthetic forms of expression.

These articles challenge preconceived notions of passivity and acquiescence of displaced and dispossessed people and communities, by encouraging the articulation of their perspectives and subjectivities. The seven articles in this special issue all have an interest in the aesthetic expressions of the displaced, the dispossessed, and the migrant, both the mobility of the forced migrant and the universal aesthetics of expression. They offer a unique perspective on the rebuilt lives, identities, and expressions of displaced people in their newly defined worlds in the grey zone between nation-states.

Marfleet's article provides an overview of many of the themes outlined above. He addresses two closely related issues: why do dominant discourses marginalize or even exclude refugee experiences, and how can such experiences be "recuperated"? Throughout the modern era, nation-state and state bureaucracies have rendered refugees as "the other." Using examples from Europe, North America, Asia, Africa, and Australasia, he examines the purposes of such exclusion and the implications for refugees in the wider human society. Marfleet considers the relationship between the experience of displacement and the means of reflecting upon it. What does it mean to narrate life-changing experiences? How are they transmitted across generations and by "post-memory"? What distinguishes individual from collective memories? And finally, is it enough to "give voice" to refugees?

Fiske's contends with the cry of detained refugees "We are human, not animals," which is often called out or painted on banners during protests against detention when they seek asylum in Western states. Drawing on material from fieldwork in Australia and linking the struggles of refugees there to global trends toward rejection of universal human rights, Fiske attempts to make sense of the dehumanizing discourses and punitive polices as well as hard-line responses to detainee protests that she witnessed. Using Hannah Arendt's contention that conscience, speech, and action are "essential characteristics of the human condition,"
(C) Author(s), 2016. This open-access work is licensed under a Creative Commons Attribution-NonCommercial 4.0 International license.
Cette oeuvre en libre accès fait l'object d'une licence Creative Commons Attribution-NonCommercial 4.0 International. 
she regards the actions of refugees as both a response to the dehumanising effects of detention and political exclusion, and an assertion that while a human being may be politically stripped of these "essential characteristics of the human conditions," they are inherent in the human condition and agency always remains with the agent. Refugees, she argues, use their "bare humanity" to reclaim human status and a place in the public world.

Hughes turns a historical eye on the meaning of forced migration and settlement though the voices of displaced people and refugees in Germany after the Second World War. She explores how being expelled from childhood homes and placed in "homes by chance" led to the constant re-evaluation of what home means, materially and symbol ically, among those so displaced. She identifies three main phases of narration of home: loss, itinerancy, and settlement. The loss of home was experienced as traumatic, when home was emptied of all its material and symbolic content. The itinerancy phase was marked by deprivation, living in other peoples' homes, and difficult relationships between the expelled and receiving communities. The final period is the making of a new "home," where the physical, emotional, and social process of homemaking are reintegrated. The constant contestation and negotiation of home by those who have been expelled has led to an imagined, idealized, and romanticized notion of the "homeland." These conclusions help to make sense of the widespread and common memory among forced migrants and refugees of the homeland often more mythological than grounded in physical space.

Berhman turns to literature to try to understand the way in which the "place" of the refugee has been transformed over the last half-century. He sees two distinct but interlocking processes: the birth of nations in the post-colonial world and the coming of refugee law. Both historic developments highlight the changing fortunes of the refugee. Berhman argues that the negative perceptions of the refugee today are intimately linked to the romanticization of the forced migrant in an earlier era. He examines three novels that deal with the refugee against the background of the emergence of post-colonial nations: Leon Uris's Exodus (1958), Salman Rushdie's Shame (1983), and Benjamin Zephaniah's Refugee Boy (2001). Behrman argues that is it precisely within the contractions of national liberation and of refugee law that the refugee has been caught. The recovery of the refugee as a valorized subject thus depends as much on eschewing the romantic hero of the past as of resisting the debased construction of the refugee that dominates today.

The final three articles draw on field studies in Africa. McQuaid examines how Congolese refugees remake their worlds in Uganda and how they defy both legal and humanitarian frameworks to fight to give voice to the voiceless. Drawing on fieldwork among Congolese human rights defenders, she examines their narratives and experiences as they navigate multiple forms and perpetrators of violence through social action. McQuaid clearly illustrates how Congolese refugees understand, articulate, and deploy notions of human rights as well as how they are shaped by the realities of life in displacement. Dona and Godin examine how new information and communications technologies promote the expression of diasporic and refugee voices outside the nation-state-in transnational and trans-generational spaces that enable the creation of narratives that are both lived and alive. Using material drawn from research with second-generation Congolese and Rwandan forced migrants, the authors clearly identify the way in which these forced migrants express their voices and agency in virtual space. Deramo examines how the production of refugee stories, opinions, and perspectives counter the bio-power of the state. Using as a case study the KANERE Press, a free press founded and produced by exiled journalists living in Kakuma refugee camp in Kenya, she addresses how story and narrative produce a transgressive public sphere in an environment where human rights are routinely violated and the rights to speech and expression are repressed. Deramo argues that the refugee camp is a technology of power that operates to manage and ultimately to subjugate populations whose fate as displaced persons is determined by the nation-state. As refugees tell their stories of life in the camp, they construct a narrative community that exists beyond the control of the camp administration, thereby constructing a politicized public sphere. The persistence of KANERE demonstrates a manner of continued resistance that operates in direct opposition to the ethic of control embedded in bio-power.

These seven articles address the nature of voice, memory, identity, and aesthetic expression of the forced migrant from a variety of perspectives within the social sciences as well as the humanities. Using historical as well as contemporary field material, the authors grapple with the silencing as well as "othering" of the forced migrant and refugee in the context of the nation-state. They also examine and articulate the numerous measures used by advocates and the dispossessed in the grey area between states to express their aesthetics and resilience. Through words and images, forced migrants in the grey zone between states are sometimes able to counter official humanitarian discourse and at other times to extend their impact beyond such narratives to reiterate their common humanity.

Dawn Chatty is emeritus professor of anthropology and forced migration, University of Oxford. The author may be contacted atdawn.chatty@qeh.ox.ac.uk.
(C) Author(s), 2016. This open-access work is licensed under a

Creative Commons Attribution-NonCommercial 4.0 International license.
Cette oeuvre en libre accès fait l'object d'une licence Creative Commons Attribution-NonCommercial 4.0 International. 


\section{Notes}

1 James Scott, The Art of Not Being Governed: An Anarchist History of Southeast Asia (New Haven, ст: Yale University Press, 2009).

2 Jacques Maquet, The Aesthetic Experience: An Anthropologist Looks at the Visual Arts (New Haven, ст: Yale University Press, 1986), 8.

3 Ibid.

4 Ibid.

5 Alfred Gell, "The Technology of Enchantment and the Enchantment of Technology," in Anthropology, Art and
Aesthetics, ed. Jeremy Coote and Anthony Shelton, 40-66 (Oxford: Clarendon, 1992). See also Jeremy Coote, "Marvels of Everyday Vision': The Anthropology of Aesthetics and the Cattle Keeping Nilotes," in Anthropology, Art, and Aesthetics, ed. Jeremy Coote and Anthony Shelton, 245-73 (Oxford: Clarendon, 1992).

6 Steven Caton, Peaks of Yemen I Summon: Poetry as Cultural Practice in a North Yemeni Tribe (Berkeley: University of California Press, 1990). 


\title{
Displacements of Memory
}

\author{
PHILIP MARFLEET
}

\section{Abstract}

The experiences of refugees - their "voices" and memorieshave routinely been excluded from the historical record. With rare exceptions, refugees are absent from mainstream history: although specific episodes of forced migration may be carefully recorded and even celebrated in national histories, most refugee movements are ignored and their participants silenced. This article examines the practice of exclusion and its implications for historical research and for the study of forced migration. It considers experiences of refugees from the early modern era until the twenty-first century, mobilizing examples from Europe, the Americas, and South Asia, and offering comparative observations. It examines relationships between forced migrants and institutions of the nation-state, and the meanings of exclusion within ideologies of national belonging. It considers remedial measures and their implications for current efforts to ensure refugee voices are heard and understood.

\section{Résumé}

Les expériences des réfugiés-leurs "voix» et leurs souvenirs-ont été exclues de façon systématique des chroniques et témoignages historiques. Sauf quelques rares exceptions, les réfugiés sont absents de l'histoire conventionnelle. Bien que des instances spécifiques de migrations forcées soient soigneusement documentées et même commémorées dans le cadre des histoires nationales, la majorité des mouvements de réfugiés sont ignorés et leurs participants sont réduits au silence. Cet article examine la pratique de l'exclusion et ses implications pour la recherche historique, ainsi que pour l'étude de la migration forcée. Il considère les expériences des réfugiés depuis les débuts de l'ère moderne jusqu'au $\mathrm{xxI}^{e}$ siècle, en rassemblant des cas provenant de l'Europe, des Amériques et de l'Asie du
Sud, et offrant des observations comparatives. Il se penche sur les liens entre les migrants forcés et les institutions de l'état-nation, ainsi que sur la signification de l'exclusion dans le contexte des idéologies d'appartenance nationale. Il étudie des mesures de réparation et leurs implications pour les initiatives actuelles visant à garantir que les voix des réfugiés sont entendues et comprises.

\section{"Collective Amnesia"}

$\mathrm{F}$ or centuries refugees have been associated with processes of enormous importance to the modern world order. Their experiences have rarely been of interest to archivists and professional historians, however, with the result that refugee voices are largely absent from mainstream history. What explains this striking deficit-and what measures might be taken to enable a different approach?

Emergence of the nation-state in the early modern era was closely associated with major episodes of forced migration in Europe. The term réfugié was coined during this period, and refugees, often referred to as "exiles," were widely dispersed across the new states. ${ }^{1}$ As the nation-state became the dominant form of socio-political organization worldwide, forced migration became more general: by the twentieth century, refugee movements were on such a scale that influential states collaborated to produce the first formal measures to recognize and manage mass displacement. ${ }^{2}$ The refugee experience was nonetheless seldom viewed as a matter of intrinsic interest, and refugees were largely absent from the historical record. Tony Kushner and Katherine Knox describe a "general silence on refugee questions in the discipline [history]." 3 They continue, "If their [refugees'] presence is one of 'the hallmarks of our time,' then modern and contemporary historians have hardly noticed it."4

The practice of exclusion has been evident, even in relation to major episodes of forced migration. For example, in 1914 some 250,00o Belgian refugees arrived in Britain, fleeing
(C) Author(s), 2016. This open-access work is licensed under a Creative Commons Attribution-NonCommercial 4.0 International license.
Cette oeuvre en libre accès fait l'object d'une licence Creative Commons Attribution-NonCommercial 4.0 International. 
German military offensives at the start of the First World War. Their migration involved the largest refugee movement in British history, but for almost a century it was "forgotten." Historians did not recognize the Belgians' arrival, their experiences in Britain, or their hasty departure at the end of the war-an expression of what Tony Kushner calls "collective amnesia" in relation to the refugees 5 - and it was almost one hundred years before researchers stimulated by growing attention in Britain to family and community history began systematic work on the 1914 migrations. ${ }^{6}$ Records of the Great War, part of the dominant narrative of British history in the twentieth century, silenced the refugees: neither their experiences nor those of millions of people with whom they came into contact had been judged worthy of interest by professional historians.

The Belgian migrations of 1914 were striking in many ways, including the very large numbers involved, the abrupt arrivals, the enthusiastic public reception, and the hesitant and contradictory responses of government. They mark an important episode-one ignored by professional historians until addressed by Peter Cahalan in Belgian Refugee Relief in England during the Great War, published in 1982.? Reviewing refugee movements in Britain during the twentieth century, Kushner and Knox comment that, given the importance of the Belgian migrations, it is significant that Cahalan's book remained for decades the only major study of the movement. ${ }^{8}$ When Pierre Purseigle examined the events again, twenty years after Cahalan's landmark publication, he observed, "The experiences of the four million people who fled their homes before the [German] invasion have been surprisingly neglected, as if historiography and collective memory alike concurred in marginalising the Western Front refugees."9

Many major episodes of mass displacement have similarly "disappeared" from official history-from accounts that constitute what the Indian historian Gyanendra Pandey calls "national memory." 10 Until the emergence of the school of world history in 1970s, scholarly research in Europe and North America was shaped almost exclusively by national concerns. ${ }^{11}$ Methodological nationalism confined perspectives on the past: the nation-state framework and the agendas of those in authority in the state (or those who wished for such authority) constituted what Wimmer and Glick Schiller call an "iron cage," confining and limiting historical analysis. ${ }^{12}$ History as an account of the past framed in national terms largely excluded outsiders, especially those who arrived as part of abrupt or unexpected population movements. Since emergence of the nationstate in the early modern era, control of state borders and of population movements had been key issues for those holding authority in institutions of government. People attempting to cross borders in unplanned movements were often viewed as a threat to territorial and socio-cultural integrity. With certain important exceptions, their admission was inhibited; they were often detained, deported, or repatriated. Exclusion was sometimes publicized widely in efforts to assert governmental authority, but as a rule those rejected or expelled were "forgotten"-victims of a general amnesia about refugees. ${ }^{13}$

\section{Silences of Partition}

This pattern continued down the centuries. Partition of the colonial state of India, enacted formally in 1947, produced a series of complex mass displacements. For almost forty years, however, a fictional work, Kushwant Singh's Train to Pakistan, was the only focused attempt to address the experiences of those affected. ${ }^{14}$ Singh had been a witness to migrations in which millions of people were compelled to undertake dangerous journeys to uncertain destinations. Many were affected by extreme violence as two new independent states, India and Pakistan, were established amid intense ethno-religious conflict. Opening his novel, published in 1956, Singh wrote, "Muslims said the Hindus had planned and started the killing. According to the Hindus, the Muslims were to blame. The fact is, both sides killed. Both shot and stabbed and speared and clubbed. Both tortured. Both raped ... all of northern India was in arms, in terror or in hiding." 15

The experiential aspect of these events was, however, "forgotten" by historians, politicians, and mass media. While mainstream accounts focused on political figures and "decisions made far away,"16 millions of people directly affected, observes Tarun Saint, remained "neglected aspects of this catastrophe."17 Decades passed after publication of Train to Pakistan before the first systematic research into the clashes of 1947 and their long-term consequences. ${ }^{18}$ Saint observes that this required a radical reorientation among historians in relation to Partition-a "reconfiguring" of the historical archive. ${ }^{19}$

Mainstream history in India, says Urvashi Butalia, assumed that Partition was "over, done with, a thing of the past." ${ }^{20}$ In the late 1980 o feminist historians began to investigate experiences of those affected by communal conflict and mass displacement, revealing that Partition had been less a specific episode than a continuous experience over decades of separation and exclusion, sometimes of intimidation and further violence-what Vazira Zamindar calls "the long Partition." ${ }^{21}$ Challenging the dominant historical narrative, Butalia suggests that "all around us was a different reality: partitions everywhere, communal tension, religious fundamentalism, continuing divisions on the basis of religion."22

In order to understand both the displacements of 1947 and their outcomes, it is necessary to focus upon those
(C) Author(s), 2016. This open-access work is licensed under a Creative Commons Attribution-NonCommercial 4.0 International license.
Cette oeuvre en libre accès fait l'object d'une licence Creative Commons Attribution-NonCommercial 4.0 International. 
affected, Butalia suggests. This requires attention to the past as a lived experience and as experience recalled-for "memories, individual and collective, familial and historical, are what make up the reality of Partition." 23 According to this view, mass displacement and the making of refugees have a profound, long-term impact on individual lives and on the wider society. In the case of Partition, displacement should be viewed less as a series of events than as a process associated with powerful socio-political forces that both maintained structures of exclusion and sought to deny their purpose and effect. "Official" history often sanitizes such processes, ignoring the testimony of those who might question the dominant account and who might challenge the practices of the state today. Here is an indication as to the significance of historians' silence on refugees' experiences, for the latter can challenge and even subvert both official accounts and contemporary attitudes that rest upon them. To understand Partition then and now, Butalia concludes, official records must be questioned by "turning the historical lens to a somewhat different angle." 24 This requires attention to oral narrative: a willingness to hear testimony and to engage with memory.

\section{Nations, Denial, and "Forgetting"}

Foundational events in the histories of nation-states are often associated with mass movements of people affected by inclusion/exclusion in relation to both cultural boundaries and physical territories of the state. This is examined in the Indian context in Kushwant Singh's Train to Pakistan. Here a small rural community, Mano Majra, is home to Sikhs, Hindus, Muslims, and Christians. Notwithstanding their differences, each has engaged with the others and each venerates the local deity, a rock that stands in the centre of the village. Mano Majra is connected to cities east and west by the railway, and in the summer of 1947 "ghost trains" begin to arrive in the village loaded with the corpses of people from afar. They bring communal conflicts that dwarf the minor disputes of village life, and many people leave in fear. As the local death toll mounts, more trains arrive. A mass grave is dug, bodies are buried, and the pit is closed: "The place looked like the scar of a healed-up wound," writes Singh, but "nobody wanted to know who the dead people were." 25

Singh's words were prophetic. In the new Indian state there was little space for critical reflection on experiences of those present at its birth or on the implications for contemporary society. For decades "national memory" depicted Partition as a series of discrete events in which new borders emerged and new institutions were established; the searing violence of 1947 and its long-term impact on countless communities was officially "forgotten." Ideologues of the new India, says Pandey, together with "the long arm of the publishing houses and modern media and the homogenisation of culture" produced and disseminated a particular memory - that centred on the state itself and its agenda for national integration and development. ${ }^{26}$ Denial and forgetting have long been integral to histories of the nation-state. Almost without exception, modern states have been born in violent circumstances-wars, military occupations, civil conflicts, revolutions, and campaigns of exclusion that aim to discipline volatile populations and/or to secure forms of ethno-religious homogeneity, facilitating new ideologies of national belonging. For Ernest Renan, writing in the $188 \mathrm{os}$, "Forgetting, I would even go so far as to say historical error, is a crucial factor in the creation of a nation, which is why progress in historical studies often constitutes a danger for [the principle of] nationality. Indeed, historical enquiry brings to light deeds of violence which took place at the origin of all political formations, even of those whose consequences have been altogether beneficial. Unity is always effected by means of brutality." 27

For Renan, a partisan of liberal nationalism, even "beneficial" outcomes were intimately associated with experiences of violence later discarded from memories of nation. This involved "error"-the omission of key historic episodes that in the case of France included massacres of those who resisted subordination to central authority. ${ }^{28}$ Although reflections on the past never embrace the presence of all historic actors (history is famously written "by the victors"), Renan's observations highlight how narratives of nation may exclude entire communities, ethno-religious groups, and regional populations. In the early modern era, absolutist states in Europe organized repeated mass expulsions, first in Spain and then in Portugal, in which centralizing monarchies removed large numbers of Jews and Muslims whose religious affiliation they deemed incompatible with the Catholicism of the Crown. The practice was repeated in France, where the state-building project was closely associated with imposition of religious orthodoxy, resulting in displacement of many members of the Protestant minority. By the nineteenth century, as "nationalization" swept Europe from west to east, construction of nation-states proper involved displacement of many ethno-religious and linguistic groups. This increasingly took the form of campaigns of exclusion in which removal of a target population was enforced by armies, militias, and officials of the state or putative state, after which return of those displaced was prevented on the basis that their "race," religion, language, or traditions were incompatible with those of national society. Philipp Ther comments on the importance for socio-political arrangements across the continent, asserting, "Ethnic cleansing is a product of the nation-state and hence one of the basic components of Eur$o p e$ " (emphasis added). ${ }^{29}$ Related forms of displacement by
(C) Author(s), 2016. This open-access work is licensed under a Creative Commons Attribution-NonCommercial 4.0 International license.
Cette oeuvre en libre accès fait l'object d'une licence Creative Commons Attribution-NonCommercial 4.0 International. 
states, proto-states, and national movements have included deportation, "transfer," resettlement, "repatriation," and-in the case of the most focused campaigns-genocide. ${ }^{30}$ At the same time, colonial powers deported certain groups (including religious dissenters, political radicals, and petty criminals) to their overseas territories, so that colonial settlement was linked to consolidating national identity in the domestic context. Mass displacement was integral to the making of the modern state-centred order and to this extent forced migrants were part of that order, necessary to its development and consolidation.

As mass displacement in and from Europe gathered pace, those affected experienced a common difficulty - that of their vulnerability vis-à-vis those in authority in the new states. Forced migrants had long been disadvantaged in relation to central authorities, principally imperial powers, religious institutions, and local power-holders. The state-making process intensified these problems. It stimulated mass displacement and directed attention to new borders, greatly increasing the vulnerability of those in flight. As Soguk makes clear in the case of France, the centralizing state mapped domestic territory much more precisely than before, introducing policies of surveillance that required statistics and registers, and attempting to regulate "internal" migrations..$^{31}$ Those who sought protection abroad as refugees faced not only the problem of their dispossession (and associated loss of key resources) but also vulnerability vis-à-vis organs of the states to which they journeyed-the latter's police forces, border patrols, judicial authorities, and officials who assessed appeals for refuge. Those who sought security abroad were people upon whom the state itself practised policies of the kind that brought about refugee exclusions.

A key feature of the new states was the claim of central authorities to a monopoly of means of violence. Monarchies, parliaments, and assemblies wrote new legal codes, established new judicial and penal systems, and constructed or substantially reformed police forces, standing armies, and volunteer reserves. ${ }^{32}$ At the same time ideologues of the state, including academics, officials, and popular writers worked energetically to disseminate ideas about national affiliation and responsibilities to those in authority. The nation was presented as timeless, familial ("motherland"/“fatherland"), and guarantor of security and integrity vis-à-vis Others. Displaced people, even those formally accepted as refugees, were seldom placed within these accounts. Most remained outsiders without influence on major institutions of public life.

Billig observes that Renan's insight on the subject of forgetting has important implications: "Once a nation is established it depends for its existence upon a collective amnesia," he suggests, adding, "The dialectic, however, is more complex than Renan implied. Not only is the past forgotten, as it is ostensibly being recalled, but so there is a parallel forgetting of the present." 33 Recounting foundational myths and reflecting upon traditions and symbols of the nation embed practices "in which nationhood is mindlessly and countlessly flagged." 34 Here the past shapes everyday life. With its "banal" repetition of the discourse of nation, history continuously reasserts principles of inclusion and exclusion. The nation is projected onto Others: indeed it seeks Others and at the same time denies them a place in national society. The nation is fascinated by outsiders but, to paraphrase Kushwant Singh, no one wishes to learn who they are or to understand their circumstances, experiences, and aspirations: these are in fact systematically negated.

This is especially marked in nation-states to which there have been multiple migrations. In the case of the United States, argues Behdad, "amnesiac" practices are part of a process by which the nation has been continuously fashioned as a unified imagined community.35 A rare example of a state in which historians have celebrated the foundational role of migrants (the "Pilgrim Fathers" of the seventeenth century), the United States has nonetheless developed and maintained histories of nation in which incomers have been systematically excluded. This amounts to a practice of "historical disavowal" embedded in national culture, suggests Behdad. ${ }^{6}$ It has been practised in the United States vis-à-vis indigenous people, in relation to people of African origin enslaved before and after colonial rule, to Mexicans of the border-wars period, and to international migrants of the "melting pot" era of the late nineteenth and early twentieth centuries. It is also evident in recent border crises during which the state's techniques of coercion and discipline, exerted against forced migrants, "enable a normalized sense of national identity." 37

\section{National Liberation and Exclusion}

"Nationalization" of European society in the eighteenth and nineteenth centuries was driven not only by the imperative of achieving control over local territories and populations but also by competition among states, especially in the colonial arena. In the Americas, Asia, Africa, and the Middle East, European powers established states that mimicked those of metropolitan society-with (notionally) fixed borders and centralized political regimes. Colonial states rarely had an official history as such: they were viewed within the national histories of Europe as sites for pioneering deeds and civilizing missions in which colonial subjects were present largely as the focus of metropolitan policy. In the case of colonial genocides such as those perpetrated in the Americas, Africa, and Australasia, mainstream history was for generations a practice of institutional forgetting in which those encountered by the colonizers were marked
(C) Author(s), 2016. This open-access work is licensed under a Creative Commons Attribution-NonCommercial 4.0 International license.
Cette oeuvre en libre accès fait l'object d'une licence Creative Commons Attribution-NonCommercial 4.0 International. 
solely by their absence. In the context of "voice," we might say that the silence of indigenous people in official records and in academic narratives was deafening.

Movements for national self-determination in the colonies brought a modified approach. National histories in new independent polities such as the United States of America addressed colonization and its outcomes: they did not, however, change practices by which those in authority placed themselves centrally within the historical record, marginalizing or excluding others as part of the exercise of power. In the case of the United States, liberation from Britain was accompanied by a new surge of colonization to the south and west, and by an ideology of nation-building in which Native Americans, African Americans, Mexicans, and many others were systematically excluded. The paradox of nationalism, what Tom Nairn calls its "Janus-face," was starkly clear: $3^{8}$ like European nationalisms, movements for liberation from colonial rule established national categories that referenced a specific past (usually based on highly charged myths of origin), rejected "non-national" Others, and developed narratives of contemporary history in which the latter had no place. This pattern was particularly marked in Latin America as independent states emerged in the in nineteenth century, continuing into the twentieth century and the post-colonial era in Africa and Asia. Here retreat of colonial powers was often associated with conflicts in which projects for independence were shaped by struggles against external enemies (usually the colonizers) and "internal" rivals emplaced by European administrations for which unity of the colonial state had been premised upon identification of ethno-religious, sectarian, or regional difference (the practice of divide et impera). Even in rare cases in which "nation-building" proceeded without major conflict in relation to the colonial power or local rivals, discourses of national unity required a heightened sense of belonging and readiness to participate actively in practices of exclusion. In the 1960 s, as European powers retreated from some parts of Africa, the construction of Tanzania as an independent state was viewed as a uniquely peaceful transition from British rule, with limited use of state violence to repress competing identities of "race," ethnicity, and religion. Even here, however, notes Ronald Aminzade, "violence or the threat of it was an intrinsic part of the formation of the Tanzanian nation." 39 Tanzania's first president, Julius Nyerere, declared that the key weapons required by the state were the plough and the gun-the latter being necessitated because Tanzania required "identification of those who were actual or potential enemies of the nation" and readiness to confront them. ${ }^{40}$

By the late nineteenth century most of the Global South had been comprehensively "nationalized." Among the last regions to be affected were territories of the Ottoman Empire, where with the support of European powers new states were established in the Balkans and later in Anatolia, the Arab East, and the Arabian Peninsula. During the First World War, what remained of the empire was dissected and its territories distributed between the two dominant European powers, Britain and France. Everywhere the process was accompanied by mass displacement, as "non-national" populations were expelled, often after intense and violent conflict. ${ }^{41}$ It included genocidal assaults on "minority" populations in Anatolia during the First World War and ethnic cleansing in Palestine thirty years later. Each was associated with mass displacement that had a lasting effect in many states of the region.

Anatolia had been a zone of special cultural heterogeneity, home to people of diverse linguistic groups and ethnoreligious affiliations, including numerous Muslim, Christian, Jewish, and syncretic currents. The Turkish republic that came into existence in 1923 enforced new principles of national belonging under which those deemed insufficiently Turkish were penalized aggressively. Aktar writes of "homogenising the nation"-a process supported energetically by republican intellectuals. ${ }^{42}$ Keyder observes that for almost a century these ideologues of the new state ignored upheavals associated with its establishment and the fate of diverse communities of Ottoman Anatolia. 43 "The principal event of the nationalist struggle was repressed in the collective memory of the [Turkish] nation," Keyder argues; what remained of the multi-ethnicity of the Ottoman era was "silence." 44 At the same time, incoming migrants-notably those who moved as part of population "exchanges" with the independent state of Greece-were marginalized within Turkish society. These refugees, formally placed within a new national homeland, were deemed “"'others,' those who were not really of us." 45

In the case of Palestine, a complex multi-ethnic society was transformed in 1948 into an ethnocentric state. Ideologues of the new Israel elaborated a highly contentious account of local history in which the indigenous population had no significant role. Palestinians were silenced by the impacts of mass displacement and by an ideological agenda that celebrated certain traditions, rights, and achievements embedded in the new national agenda. At the same time they were affected by continuous efforts of the Israeli state to enforce further ethnic cleansing, a process described by Yiftachel as "ethno-spatial domination and exclusion."46

The dominant Zionist account of foundational events in Israel can be seen as a paradigmatic example of Renan's contention that "deeds of violence" are excluded from the national narrative. Those who have challenged this record, notably Palestinian academics and Israel's "revisionist"
(C) Author(s), 2016. This open-access work is licensed under a Creative Commons Attribution-NonCommercial 4.0 International license.
Cette oeuvre en libre accès fait l'object d'une licence Creative Commons Attribution-NonCommercial 4.0 International. 
historians, have often been accused of seeking to "delegitimize" the Israel state-a marker of the importance of the past in contemporary politics. 47 The Palestinian experience also reveals the significance of mass displacement as a functional practice for exclusionary regimes. Most of the Palestinians displaced in 1948, and their descendants to the fourth or even fifth generation, remain in "camps" and settlements in Arab states and in Israel and Israeli-occupied territories, while "internal" displacement (within the borders of Israel) continues. Exclusion of Palestinian Arabs appears to be an existential principle for the Zionist movement. Here, the violence of the "founding fathers" is revisited continuously upon a historic Other.

\section{Vulnerable Migrants}

In some specific contexts, forced migrants have been integrated into mainstream history and play a key role in narratives of the nation. In colonial-settler states such as South Africa and Australia, European migrants-including transportees and "exiles"-bring progressive change to regions perceived as backward or even "empty." 48 In both the United States and Israel, stories about foundational episodes in construction of the state incorporate refugees. Roger Daniels memorably comments that the Pilgrim Fathers, religious dissenters from Europe allocated a key role in the settlement in colonial North America, have been represented as "the kind of people American myth-makers ... liked to imagine we were descended from." 49 In Israel, the story of refugees from Europe who journeyed to Palestine (most as survivors of fascism and related hyper-nationalisms) is integral to Zionist narratives of Israel as a Jewish national homeland.

Among people displaced in the mid-twentieth century during Partition of colonial India, most soon disappeared from histories of South Asia-indeed most disappeared even from journalistic coverage of contemporary affairs. In the case of Pakistan, however, certain migrants were periodically a focus of attention. Their experiences, observes Khan, were "woven into the fabric of national history."50 Judged suitable for assimilation into official accounts, they were identified as shuhada ("witnesses"-martyrs), "bathed in the language of martyrdom" as part of efforts in the new state to repackage Partition as "a war of liberation." 51 These refugees have been viewed both as victims of India's ethnic separatism and, paradoxically, as agents of political changein this case the construction of a religiously sanctioned state in which key foundational episodes were facilitated by mass martyrdom. Here refugee voices are made to speak on behalf of those who shape national memory. Millions of non-Muslims evicted from territories that became part of the new state meanwhile remained invisible and silent.
The vulnerability of displaced people is a key factor in understanding how readily some refugees are excluded from or integrated into dominant narratives. This was especially clear in the Cold War era of the mid-twentieth century when refugees were first defined in legal terms, and movements of people between East and West (viewed as political blocs) became a matter of ideological importance. The presence of people granted asylum who originated in states of a rival bloc was seen as a means of embellishing values of the receiving society. Tuitt comments that refugees functioned as "ambassadors of the Cold War period ... living witnesses of 'corrupt,' 'evil' and 'oppressive' governments and to the 'heraldry' of the host state." 52 In these circumstances, refugees were invited to speak publicly about their experiences, their testimony integrated into the rhetoric of imperial rivalry. Carl Bon Tempo describes developments in the United States: "Refugee admissions struck a rhetorical blow against the Soviets and reminded the world of the United States' unbending commitment to anticommunism and winning the Cold War. It is little wonder, then, that for much of the post-World War II era, Americans, from presidents to the public, associated refugees with anti-communism."53

The willingness of state authorities to promote specific refugee narratives raises important questions about means by which refugee voices can be heard. Following the Second World War, the Australian government was keen to stimulate immigration from Europe but reluctant to admit certain refugees, notably Jews. 54 Still pursuing a "white Australia" policy initiated in 1901, the authorities favoured AngloSaxon or Scandinavian immigrants; as a close ally of the United States and of European members of the Western bloc, they also sought anti-Communists-among whom were a significant number of fascists and fascist collaborators from Yugoslavia and the Baltic states. Aarons notes that in the political climate of the Cold War and in the context of attempts to suppress domestic dissidence (including banning the Australian Communist Party), leading Australian politicians "warmly welcomed these anti-Communist refugees and actively took up their causes." 55 Members of organizations such as the Croatian Ustashe, known to have been involved in some of the worst atrocities of the Second World War, were readily accommodated. Some became leading figures in mainstream political parties in Australia, notably the Liberal Party, which governed for over two decades from the late 1940s, during which time it in effect amnestied many European migrants known to be suspected of the most serious war crimes. ${ }^{56}$ Certain narratives of the refugee experience were favoured and advanced by powerful lobbies within Australian society; other stories uncongenial to these parties and networks were dismissed or even suppressed.
(C) Author(s), 2016. This open-access work is licensed under a Creative Commons Attribution-NonCommercial 4.0 International license.
Cette oeuvre en libre accès fait l'object d'une licence Creative Commons Attribution-NonCommercial 4.0 International. 


\section{Testimony and Memory}

Critical awareness of problems of exclusion and silencing has led some historians, archivists, and sympathetic researchers to address refugees in ways that challenge mainstream approaches-addressing them as social actors whose life stories, aspirations, and ambitions are of intrinsic value in understanding forced migration and wider aspects of modern society. Over the past two decades there have been focused efforts to record refugee testimony through the practice of oral history. Paul Thompson observes that "oral history is as old as history itself. It was the first kind of history." 57 Systematic collection of oral testimony in a form that could be mobilized in historical texts, however, began only in the late nineteenth century with the work of cultural anthropologists in the United States. A related current emerged fifty years later in Britain, focused upon history "from below." This introduced to the historical record those earlier excluded from history but who, argued Edward Thompson, were emphatically present in the making of the modern social order. ${ }^{8}$ Others "hidden from history" were also the focus of attention, notably women addressed in an extensive literature produced by feminist historians. 59 This field expanded rapidly: by the early 1990 s Sherna Berger Gluck and Daphne Patai could reflect on "an enormous volume of women's oral history, making available in accessible forms the words of women who had previously been silenced or ignored."6o Migrants in general received less attention. Takaki comments that even in the late 199os, Asian Americans-present in the United States for over 150 years-were entirely overlooked.6 "They are entitled to be viewed as subjects," he argued, "as men and women with minds, wills and voices." 62

Important advances in oral history had taken place in relation to survivors of the Holocaust, whose experiences were of special importance to those concerned with refugees, memory, and "voice." At the end of the Second World War, American psychologist David Boder recorded lengthy testimonies of survivors in Europe, then viewed as "displaced persons." ${ }^{33}$ His book of 1949, I Did Not Interview the Dead, is probably the first significant record of refugee testimony. ${ }^{64}$ As awareness developed of fascist atrocities in Europe during the 1930s and 1940s, there were sustained efforts to collect testimony, with projects focused on "giving voice" to survivors by compiling oral records, together with collection of written memoirs, personal histories, novels, poems, and analysis of these texts in the context of literary studies. ${ }^{65}$ Assessing these initiatives, James Young observed that the events of the Holocaust could be recorded and understood but must be set alongside an appreciation of how memory, meaning, and understanding are constructed in narrative. ${ }^{66}$ "What is remembered of the Holocaust depends on how it is remembered," he observed. ${ }^{67}$ It was not enough to "give voice" in the sense of merely reproducing testimony, Young argued, for the latter should be understood in the context of storytelling and recall. These insights had their influence on Indian scholars who had begun to reassess Partition and its outcomes: the historiography of the Holocaust and work within Holocaust studies was widely quoted in the 1990s by researchers investigating the Indian experience. ${ }^{68}$

\section{"Cultural Retrieval"}

Most refugees worldwide nonetheless remained outside or at the margins of historical enquiry. Edward Said provides a key explanation, observing that in the case of the Palestinians the weight of a dominant national discourse-the Zionist account of Israel and its modern history-inhibited development of a "socially acceptable narrative" of the Palestinian experience. ${ }^{69}$ Here, as in so many cases of displacement, refugees are silenced by powerful institutions and ideological agendas. Ted Swedenburg also notes "the relative absence of any space for Palestinians to assert their narrative," arguing that this amounts to a "censorship of Palestinian culture."7o The same author draws attention to a further difficulty that presents special problems for those attentive to the refugee experience. When in the 199os researchers began to collect Palestinian testimony, they encountered powerful narratives that claimed to authenticate the refugee experience in all-embracing ways. A resistance movement that from the 196os mobilized mass support across the Palestinian diaspora attempted to identify and formalize a national history-to "articulate subaltern memories with its [sic] hegemonic principles to create an agreed-upon definition of what 'the past' was really like."71 Here memory was shaped by a powerful narrative constructed "from below" but was also part of a specific act of collective recall. What was remembered of the nakba (the dispossession of 1948) depended on how it was remembered.

Mass displacements have often been followed by intense self-activity among refugee populations, mobilized around specific projects of national liberation or ethno-religious affiliation. These may have a long-term impact, with "memory" transmitted across generations and through social and political networks. People with no personal experience of displacement, flight, settlement, or resettlement integrate into their world view memories that derive from earlier generations and/or from a collective "recall" given weight by the influence of such movements, producing what Marianne Hirsch calls "postmemory." 72 This highlights a key problem in oral history that has recently prompted much discussion in narrative studies and "memory work." Memory, like socio-cultural identity, is fluid. It is modified continuously within the contingent circumstances of individual lives, in
(C) Author(s), 2016. This open-access work is licensed under a Creative Commons Attribution-NonCommercial 4.0 International license.
Cette oeuvre en libre accès fait l'object d'une licence Creative Commons Attribution-NonCommercial 4.0 International. 
response to changing needs and in the context of complex relations between researcher and research participant.73 Khalili notes the importance for contemporary Palestinian nationalism of discourses and acts of commemoration that are central to assertion of Palestinian identity and to the coherence of the movement. ${ }^{74}$ For almost two decades the Palestine Liberation Organisation, based in Jordan and then in Lebanon, acted as a proto-state with all the concerns of a state "proper," producing commemorative publications, establishing monuments to martyrs and massacres, and declaring commemorative days and ceremonies. After the expulsion of the armed movement from Lebanon in 1982, commemorative practices changed, reflecting the differing approaches of factions within the movement and the efforts of specific groups of Palestinians to mark local histories and experiences by including establishment of "memory museums," publication of village books, and collection of local oral histories. Khalili observes that ceremonial or narrative forms have been "appropriated, localized and transformed," as the popularization of commemorative practice challenges state-based discourses. ${ }^{75}$ Butalia makes a similar observation in relation to India, asking about the meanings of "rehearsed performances" of stories told generations after the events upon which they focus-but also insisting upon the need to find space for "the small, the individual voice." 76

\section{Conclusion: "Forgetting" the Belgians}

Amnesia has a continuous productive function for the nation-state. In a world of states, forced migrants are by definition persons with attachments to other states and cultures, potentially a source of threat that can be mobilized within discourses of national identity and social coherence. They are made to play a central role in national/nationalist dramas, especially during border crises-episodes that dramatize issues of inclusion and exclusion-in which they are allocated non-speaking parts, the script being provided by narratives embedded in national memory. Outsiders are used, in effect, as a screen onto which all manner of threats can be projected-a practice facilitated by the predicaments of certain migrants, especially refugees, whose vulnerability means that, except in rare and specific circumstances, they are rendered "silent" in the face of powerful institutions and political actors. They have a key role in narratives of nation but-paradoxically-only to the extent that they remain mute. Forgotten by history, they are silenced in the present.

Today the accounts of forced migrants seeking sanctuary in desired countries of asylum in the Global North are routinely viewed as fanciful or false, treated with disbelief and dismissed in line with policies that view uninvited migrants as intruders or even as enemies.77 In these circumstances refugees are rendered voiceless in the sense that they have few or no resources with which to address their circumstances: against a din of official noise amplified by the state itself and by mass media, they go unheard. Their stories, however, are matters of importance for the wider society. Economic change and political and ethno-religious conflicts associated with mass displacement often have feedback effects at the local or even regional level. They are part of the process by which states or proto-states come into being, by which governmental authorities attempt to assert legitimacy, and regimes of exclusion are established and maintained. As Pradip Kumar Bose observes in the case of India, the more that researchers probe how "the common people" experienced Partition, the more attention is paid to Partition as an active element in the life of contemporary society. ${ }^{78}$ Here Partition is not "as a leaf in archives, but as renewal, as currency, as presence." 79

National memory is a powerful influence on popular attitudes but also one subject to disruption and subversion. Histories of the nation-state give ample evidence of difficulties faced by those in authority in maintaining ideas about national belonging. Although migrants have often been used to energize such notions, they can also been seen as a focal point for solidarity, as popular ethics challenge dominant ideas about threat and exclusion. In 1914 a British government reluctant to accept refugees from Belgium was forced to come to terms with a public mood of empathy and support for the migrants, as both official history and popular notions about refuge, protection, and hospitality influenced the public response. Cahalan notes that the Belgians' plight prompted a search for means to understand their presence, with mainstream British history providing an important resource-ordinary people "delved into the past to place the Belgian refugees in context, and their search for a usable past took some back as far as the French Huguenots and other Protestant exiles." ${ }^{\circ}$ At the same time, popular attitudes challenged a government not only reluctant to change unprecedentedly restrictive policies on asylum but also about to embark on mass incarceration (in the form of internment) of people deemed enemy aliens. ${ }^{81}$ The government's Belgian Refugee Committee, reporting weeks after the first arrivals, noted widespread public support. Reception at British ports, it recorded, "was entirely carried out by volunteers." 82 The committee reported, without irony, "The chief complaints have been from eager hosts to whom suitable [sic] refugees were not sent as quickly or as to the extent they desired." 83 As the conflict continued, at terrible cost in the war zone and on the domestic front, public support for the refugees ebbed and there was little resistance to a government campaign that by 1919 had repatriated most Belgian refugees. As they disappeared from British towns and cities, they were removed from the official record of
(C) Author(s), 2016. This open-access work is licensed under a Creative Commons Attribution-NonCommercial 4.0 International license.
Cette oeuvre en libre accès fait l'object d'une licence Creative Commons Attribution-NonCommercial 4.0 International. 
traumatic events, leaving only a trace in local archives and in popular memory.

At the end of the war, the British government expelled all manner of people deemed out of place, including thousands of troops earlier mobilized from the colonies. ${ }^{84}$ Borders were closed and immigration radically reduced as Britain, like other states of Europe and North America, entered an era of autarky. People in urgent need of refuge were once more rejected outright-notably Jewish refugees who only years before the First World War had been the main object of exclusions formalized by the Aliens Act. The reception and accommodation of the Belgians in 1914 was an inconvenient chapter in recent history and one that politicians and historians alike preferred to ignore.

If mass displacement is part of the modern socio-political order, so too are the experiences and memories of refugees and those who empathize and solidarize with them. They are not only profoundly important for those affected but-understood in the context of their transmission and representation-of real significance for understanding contemporary realities.

Philip Marfleet is professor of migration and refugee studies at the University of East London, UK. The author may be contacted atp.marfleet@uel.ac.uk.

\section{Notes}

1 Anglicised as refugee, the term seems to have entered general use following the mass movement of French Calvinists, the Huguenots, during the early 1680s. See Anne Dunan-Page, The Religious Culture of the Huguenots, 1660-1750 (Aldershot, UK: Ashgate, 2006), 24.

2 Initially through the League of Nations, later by means of agreements facilitated by the United Nations and formalized in 1951 in the form of the Convention relating to the Status of Refugees-the "Geneva Convention."

3 Tony Kushner and Katherine Knox, Refugees in an Age of Genocide (Abingdon, UK: Frank Cass, 1999), 4.

4 Here Kushner and Knox quote Michael Marrus, who notes that the presence of refugees in the twentieth century is "one of the hallmarks of our time." Kushner and Knox, Refugees in an Age of Genocide, 4; see Michael Marrus, The Unwanted: European Refugees in the Twentieth Century (Oxford: Oxford University Press, 1985), 11.

5 Tony Kushner, Remembering Refugees: Then and Now (Manchester, UK: Manchester University Press, 2006), 234.

6 The Centre for Research on Belgian Refugees was established in 2012, initially at Imperial College, London. See http://belgianrefugees.blogspot.co.uk/2012/o2/gettingstarted.html.

7 Peter Cahalan, Belgian Refugee Relief in England during the Great War (New York: Garland, 1982).
8 Kushner and Knox, Refugees in an Age of Genocide, 49. Kushner and Knox provide a rare and valuable account of the Belgian immigration based on research in Hampshire, southern England.

9 Pierre Purseigle, ““A Wave on to Our Shores': The Exile and Resettlement of Refugees from the Western Front, 1914-1918," Contemporary European History 16, no. 4 (2007): 427.

10 Gyanendra Pandey, Remembering Partition (Cambridge: Cambridge University Press, 2001), 9.

11 Scholarly work outside the Western academy sometimes used a different lens. Muslim scholars concerned with political and social arrangements, for example, continued until the twentieth century to reflect on transnational developments-an aspect of their concern with the umma, the collective of Muslims that predates the modern state. This was modified in the early twentieth century by imposition of the nation-state in predominantly Muslim regions.

12 Andreas Wimmer and Nina Glick Schiller, "Methodological Nationalism and Beyond: Nation-state Building, Migration and the Social Sciences," Global Networks 2, no. 2 (2002): 301-34.

13 See Philip Marfleet, "Refugees and History: Why We Must Address the Past," Refugee Survey Quarterly 26, no. 3 (2007): 136-48; Marfleet, "Explorations in a Foreign Land: States, Refugees and the Problem of History," in "Conceptual Problems in Forced Migration," special issue of Refugee Survey Quarterly 32, no. 2 (2013): 14-34.

14 Kushwant Singh, Train to Pakistan (1956; New York: Grove, 1981).

15 Ibid., 1.

16 Pippa Virdee, “"No Home but in Memory': The Legacies of Colonial Rule in the Punjab," in Refugees and the End of Empire, ed. Panikos Panay and Pippa Virdee (Basingstoke: Palgrave, 2011), 181.

17 Tarun K. Saint, Witnessing Partition: Memory, History, Fiction (New Delhi: Routledge, 2010), 2.

18 There were isolated exceptions to a general disinterest in these experiences: see, for example, Penderel Moon, Divide and Quit: An Eye-Witness Account of the Partition of India (London: Chatto \& Windus, 1962). One important study in the context of development and political change was Stephen Keller's analysis of refugee and non-refugee populations in Punjab and Haryana: see Stephen Keller, Uprooting and Social Change: The Role of Refugees in Development (New Delhi: Manohar Book Service, 1975).

19 Saint, Witnessing Partition, 2.

20 Urvashi Butalia, The Other Side of Silence: Voices from the Partition of India (New Delhi: Penguin Books India, 1998), 7.

21 Vazira Fazila-Yacoobali Zamindar, The Long Partition and the Making of Modern South Asia: Refugees, Boundaries, Histories (New York: Colombia University Press, 2007).

22 Butalia, Other Side of Silence, 7.

23 Ibid., 10.
(C) Author(s), 2016. This open-access work is licensed under a Creative Commons Attribution-NonCommercial 4.0 International license.
Cette oeuvre en libre accès fait l'object d'une licence Creative Commons Attribution-NonCommercial 4.0 International. 
24 Ibid., 13.

25 Singh, Train to Pakistan, 144-145.

26 Pandey, Remembering Partition, 9.

27 Ernest Renan, "What Is a Nation?," in Nation and Narration, ed. Homi Bhabha (Abingdon: Routledge, 1990), 11.

28 Ibid.

29 Philipp Ther, The Dark Side of Nation States: Ethnic Cleansing in Modern Europe (Oxford: Berghahn, 2014), 1.

30 For discussion of differences between these modes of displacement, see ibid., chaps. 1 and 2.

31 Nevzat Soguk, States and Strangers: Refugees and Displacements of Statecraft (Minneapolis: University of Minnesota Press, 1999).

32 In the case of Britain, see Linda Colley, Britons: Forging the Nation, 1707-1837 (London: Vintage, 1996); in relation to France, see Graham Robb, The Discovery of France (London: Picador, 2007).

33 Michael Billig, Banal Nationalism (London: Sage, 1995), 35. 34 Ibid., 38.

35 Ali Behdad, A Forgetful Nation: On Immigration and Cultural Identity in the United States (Durham, NC: Duke University Press, 2005), 23.

36 Ibid., xiii.

37 Ibid., 164.

38 See Tom Nairn, "The Modern Janus," New Left Review 1, no. 94 (1975): 3-29.

39 Ronald Aminzade, Race, Nation and Citizenship: The Case of Tanzania (Cambridge: Cambridge University Press, 2013), 166.

40 Ibid.

41 See Dawn Chatty, Displacement and Dispossession in the Modern Middle East (Cambridge: Cambridge University Press, 2010).

42 Ayhan Aktar, "Homogenising the Nation, Turkifying the Economy: The Turkish Experience of Population Exchange Reconsidered," in Crossing the Aegean: An Appraisal of the 1923 Compulsory Population Exchange between Greece and Turkey, ed. Renée Hirschon (Oxford: Berghahn, 2003), 79.

43 Çağlar Keyder, "The Consequences of the Exchange of Populations for Turkey," in Hirschon, Crossing the Aegean, 39.

44 Ibid., 48.

45 Ibid., 49-50.

46 Oren Yiftachel, Ethnocracy: Land and Identity Politics in Israel/Palestine (Philadelphia: University of Pennsylvania Press, 2006), 189.

47 See, for example Alan Dershowitz, "Countering Challenges to Israel's Legitimacy," Jerusalem Center for Public Affairs, 2011, http://jcpa.org/wp-content/uploads/2012/o2/ Kiyum-dershowitz.pdf.

48 In relation to Australia, settler history, and national narrative, see Robert Hughes, The Fatal Shore (London: Vintage, 2003).
49 Roger Daniels, Coming to America: A History of Immigration and Ethnicity in American Life (New York: Harper, 2002).

50 Yasmin Khan, The Great Partition: The Making of India and Pakistan (New Haven, ст: Yale University Press, 2008), 180.

51 Ibid., 175.

52 Patricia Tuitt, False Images: Law's Construction of the Refugee (London: Pluto, 1996), 17.

53 Carl Bon Tempo, Americans at the Gate: The United States and Refugees during the Cold War (Princeton: Princeton University Press, 2008), 4.

54 On research resources for Jewish history in Australia, see Malcolm J. Turnball, "Safe Haven: Records of the Jewish Experience in Australia," National Archives of Australia, 1999, http://guides.naa.gov.au/safe-haven/chapter2/post-45policy.aspx.

55 Mark Aarons, Sanctuary! Nazi Refugees in Australia (Melbourne: William Heinemann Australia, 1989) 115.

56 Ibid., 313.

57 Paul Thompson, Voice of the Past: Oral History (Oxford: Oxford University Press, 200o), 10.

58 Edward Thompson, The Making of the English Working Class (1963; London: Penguin, 1968) 9.

59 See, for example, the pioneer work in Britain of the History Workshop group, which in 1976 published History Workshop Journal, originally as "a journal of socialist historians," later as "a journal of socialist and feminist historians.” See http://hwj.oxfordjournals.org/. Similar initiatives were launched in the United States by, among others, Radical History Review, http://www.radicalhistoryreview. org/.

60 Sherna Berger Gluck and Daphne Patai, Women's Words: The Feminist Practice of Oral History (London: Routledge, 1991), 2.

61 Ronald Takaki, Strangers from a Different Shore: A History of Asian Americans (1989; Boston: Little, Brown, 1998), 6.

62 Ibid., 7.

63 See Alan Rosen, The Wonder of Their Voices: The 1946 Holocaust Interviews of David Boder (New York: Oxford University Press, 2010); also Voices of the Holocaust, http://voices.iit.edu/david_boder.

64 David Boder, I Did Not Interview the Dead (Champaign, IL: University of Illinois Press, 1949).

65 See, for example, letters reproduced in Anne Joseph, From the Edge of the World: The Jewish Refugee Experience through Letters and Stories (London: Valentine Mitchell, 2010). See also Andrea Reiter, Narrating the Holocaust (London: Bloomsbury, 2000), for a detailed review of written materials and analysis of their content, style, and meaning.

66 James E. Young, Writing and Rewriting the Holocaust: Narrative and the Consequences of Interpretation (Bloomington: Indiana University Press, 1988), vii.

67 Ibid., 1.
(C) Author(s), 2016. This open-access work is licensed under a Creative Commons Attribution-NonCommercial 4.0 International license.
Cette oeuvre en libre accès fait l'object d'une licence Creative Commons Attribution-NonCommercial 4.0 International. 
68 See Javeed Alam and Suresh Sharma,"Remembering Partition," Seminar 461 (1998): 98-103; also Butalia, Other Side of Silence; and Pandey, Remembering Partition.

69 Edward Said, The Politics of Dispossession: The Struggle for Palestinian Self-Determination 1969-1994 (London: Chatto \& Windus, 1994), 254.

70 Ted Swedenburg, Memories of Revolt: The 1936-1939 Rebellion and the Palestinian National Past (Fayetteville: University of Arkansas Press, 2003), 4.

71 Ibid., 18.

72 Here memories of life-changing episodes mark the lives of those who were not there to experience them. Successive generations inherit such histories through all manner of images, objects, stories, behaviours, and emotions transmitted within families, communities, and the wider culture: Marianne Hirsch, The Generation of Potstmemory: Writing and Visual Culture after the Holocaust (New York: Columbia University Press, 2012).

73 For an examination of conceptual and methodological problems, and recent debates in the field, see Molly Andrews, Corinne Squire, and Maria Tamboukou, Doing Narrative Research (London: Sage, 2013).

74 Laleh Khalili, "Commemorating Contested Lands," in Exile and Return, Predicaments of Palestinians and Jews, ed. Ann M. Lesch and Ian S. Lustick (Philadelphia: University of Pennsylvania Press, 2005), 24.

75 Ibid., 26
76 Butalia, Other Side of Silence, 12-13.

77 See, for example, research on the "culture of disbelief" and the "culture of denial" in Refugee Status Determination procedures in the United Kingdom: Olga Jubany, "Constructing Truths in a Culture of Disbelief: Understanding Asylum Screening from Within," International Sociology 26, no. 1 (2011): 74-94; and James Souter, "A Culture of Disbelief or Denial? Critiquing Refugee Status Determination in the United Kingdom," Oxford Monitor of Forced Migration 1, no. 1 (2011): 48-59.

78 Ibid.

79 Ibid., 3.

8o Cahalan, Belgian Refugee Relief, 67.

81 Panikos Panayi, Enemy in Our Midst: Germans in Britain during the First World War (Oxford: Berg, 1991).

82 "Ladies and gentlemen ... worked without rest, refusing no call made upon their services and daily acting as cooks, nurses, waiting maids, booking clerks, chauffeurs, porters and refreshment attendants." Government Belgian Refugees Committee, 1914, First Report of the Departmental Committee Appointed by the President of the Local Government Board to Consider and Report on Questions Arising in Connection with the Reception and Employment of the Belgian Refugees in this Country (London: HMSO, 1914), 5.

83 Ibid., 7.

84 Neil MacMaster, Racism in Europe 1870-2000 (Basingstoke, UK: Palgrave, 2011), chap. 4. 


\title{
Human Rights and Refugee Protest against Immigration Detention: Refugees' Struggles for Recognition as Human
}

\author{
LUCY FISKE
}

\section{Abstract}

When detainees go on hunger strike or riot or occupy the roofs of detention centres, their actions are usually narrated by governments keen to discredit them and their actions as criminal and manipulative and evidence of their barbarity and difference. A secondary, counter-narration is provided by detainee supporters who explain the actions as evidence of detainees' distress and deteriorating mental health. The voices of the actors themselves, people held in detention and taking protest action, are rarely heard in depth. Drawing on in-depth interviews with refugees formerly held in Australian immigration detention centres, and the works of Hannah Arendt, this article argues that the experience of immigration detention is fundamentally dehumanizing and that while detainee protest was aimed at attaining certain material outcomes, it also served important existential functions. The fact of protest was a rejection of a powerless state, a way for detained refugees to experience their own agency and, with it, restoration of some of the "essential characteristics of human life" and a means to use their reduction to "bare humanity" as a basis for insisting upon a place in the polis.

\section{Résumé}

Lorsque ceux qui sont détenus s'engagent dans des grèves de faim ou des émeutes, ou encore occupent le toit des centres de détention, leurs actions sont reformulées par des gouvernements, motivés par le désir de les dénigrer, en récits qui mettent en évidence leur prétendue criminalité, leur volonté manipulatrice, leur barbarie et leur différence. Un deuxième courant qui va à l'encontre de ces récits est véhiculé par les sympathisants des détenus, et consiste à montrer que leurs actions découlent de la détresse qu'ils ressentent et de la détérioration de leur santé mentale. Cependant les voix des actants eux-mêmes, notamment ceux qui sont détenus et s'engagent dans des actions de contestation, se font rarement entendre d'une manière significative. En se basant sur des entrevues en profondeur avec des réfugiés détenus antérieurement dans des centres de détention pour immigrés en Australie, ainsi que sur l'œuvre de Hannah Arendt, cet article avance que l'expérience de la détention d'immigration est profondément déshumanisante, et que les actes de contestation de la part des détenus, bien qu'ils visaient dans un premier temps certains objectifs matériels, remplissaient également des fonctions existentielles importantes. Le fait de contestation représentait le rejet d'un état d'impuissance, un moyen par lequel les réfugiés détenus pouvaient ressentir leur propre volonté d'action, et conséquemment, un rétablissement de certaines "caractéristiques essentielles de la vie humaine» ("essential characteristics of human life"). C'était également une façon de se servir de leur réduction à un état d'humanité dénudée ("bare humanity") pour insister sur leur place dans le polis ou communauté politique dans lequel ils se trouvaient. 


\section{Introduction}

7 he use of immigration detention is on the rise globally. More than one million people pass through immigration detention centres in the United States, Canada, Australia, and Europe each year. ${ }^{1}$ They are held in over-crowded, dilapidated detention centres or in modern, purpose-built facilities designed as "super-max" prisons, allocated an identification number, subjected to arbitrary rules and sometimes to arbitrary and excessive use of force, and distanced from legal protections by their incarceration. They have little knowledge and little political voice: they are non-citizens, non-people. ${ }^{2}$ Life inside immigration detention centres is precarious, filled with uncertainty and monotony and, too often, degrading treatment. As the use of immigration detention has risen, so too has detainee protest. When detainees go on a hunger strike or riot or occupy the roofs of detention centres, their actions are usually narrated by governments keen to discredit them and their actions as criminal, manipulative, and evidence of their barbarity and difference. ${ }^{3} \mathrm{~A}$ secondary, counter-narration is provided by detainee supporters who explain the actions as evidence of detainees' distress and deteriorating mental health. The voices of the actors themselves, people held in detention and taking protest action, are rarely heard in any depth. Refugees are typically presented in popular discourse as either victims or villains and almost never as conscious agents.

While most OECD countries have administrative immigration detention, Australia is unique in that its immigration detention is both mandatory and indefinite. All people who do not have lawful status in the country are detained, regardless of individual characteristics or vulnerabilities (such as psychological or physical health, age, or flight risk). There are no statutory limits to detention and, unless there is ministerial intervention, detainees are typically held until granted a visa or removed from the country, a process that can take several months to several years. Detainees have no way of predicting how long they will be incarcerated.

This article arises from a four-year study of refugee protest against immigration detention in Australia based on in-depth interviews with formerly detained refugees, during which every respondent, without prompting, said, "I am human," or "We are human."4 Using Hannah Arendt's works on human rights and The Human Condition to analyze detainee testimony, I propose that the experience of immigration detention is fundamentally dehumanizing ${ }^{6}$ and that while detainee protest was aimed at attaining certain outcomes such as obtaining access to telephones, halting forced removals, or affecting refugee status determination, it also served important existential functions. The fact of protest was a rejection of a powerless state, a way for detained refugees to experience their own agency and with it, restoration of some of the "essential characteristics of human life" and a means to use their reduction to "bare humanity" as a basis for insisting upon a place in the polis. A close reading of refugee protest gives insight into the daily relations and regimens of immigration detention centres, but also important philosophical and theoretical insights into understanding the human subject of human rights.

\section{The Human Condition and Human Rights}

"Respect. Just respect. When someone respect me I respect him, because the respect it's belong just to human. Animal won't respect you, animal will obey you, because you feed them. They don't know the respect. They walking with you, dog walking with you, suddenly without 'Excuse me' he just pee in the road. But a human, it's the respect between each other. So when we say that we are human, show some respect. That's it" (Osman)?

A recurring theme among refugees interviewed was a desire to be recognized as human. Embedded in these calls was an appeal to a shared or universal humanity and an implied belief that human status entails a guarantee of a minimum standard of treatment, an implicit acknowledgement of a human rights framework. At times respondents made overt pleas to human rights as a way to improve their situations, while at other times the inference of human rights was less explicit. Humanity and rights as referred to by refugees in immigration detention seldom arose from a substantive knowledge of international human rights laws and systems (although some participants in this research did have extensive knowledge of formal human rights systems). Detainees nonetheless found human rights to be a powerful language for articulating injustice. Every person interviewed in this research complained of feeling dehumanized and unrecognized in detention. Some compared their status to that of animals, inanimate objects, or death. Osman expressed his frustration at being reduced to a status lower than an animal: "When officer call me '0276,' I said, 'Oh God! I've got name. Your donkey or your dog and your cat has name. I'm a human like you. Don't call me by number."”

Detainees' physical survival needs were met with shelter, food, and clothing, but former detainees testified that human life entails more than physical survival. An existential aspect to human life that distinguishes humans from animals cannot be reduced to mere biology. Detainee cries of "We are human" were appeals for recognition of such an aspect. Former detainees interviewed in this work, regardless of how much they knew about formal human rights systems, shared an unshakeable belief that to be humanmorally if not legally-entitled them to certain rights.
(C) Author(s), 2016. This open-access work is licensed under a Creative Commons Attribution-NonCommercial 4.0 International license.
Cette oeuvre en libre accès fait l'object d'une licence Creative Commons Attribution-NonCommercial 4.0 International. 
Hannah Arendt's work provides a theoretical framework for better understanding why immigration detention is experienced as so utterly dehumanizing and for interrogating detainee protest as a way to resist dehumanizing regimes and insist upon a recognizably human life.

\section{Dehumanizing Categories}

Arendt makes a distinction between what and who a person is. ${ }^{8}$ A person may be identified and categorized as a woman, Jew, Muslim, asylum seeker, or "boatperson" from characteristics such as dress, appearance, or context, such as on an overcrowded boat off Australia's northern coast. 9 However, she can reveal who she is in particular, only through her own speech and action. The individual characteristics that distinguish each unique person can be discerned only through the revelations of that person, gained intersubjectively through interaction and engagement on a basis of equality. The "what" of a person can only ever be an approximation of humanity, consisting of stereotypes into which individuals are grouped with little or no regard for the uniqueness of each person. To treat a person according to what rather than who she is, Arendt contends, dehumanizes the person. She is denied the opportunity to reveal herself to the world, denied entry to the public sphere as an initiating and equal person, and reduced to a representative sample of the category into which she has been placed: "If a Negro in a white community is considered a Negro and nothing else, he loses along with his right to equality that freedom of action which is specifically human; all his deeds are now explained as 'necessary' consequence of some 'Negro' qualities; he has become some specimen of an animal species called man."10

When treated primarily or only as a representative of a group, such as "boatpeople," a person's humanness is not recognized and she is reduced to a state of biology. She then holds no specific value as an individual, and her life becomes unimportant and potentially superfluous. Detainees understood and felt this lack of individual recognition keenly. Dr. Aamer Sultan commented, "That's one of the arguments I used to leave with many Australians outside, that the government are doing that now to people who are in detention: outsiders, migrants, Arab, Muslim, it doesn't matter. What guarantee that they won't do the same to someone else outside? Started with the homeless people, the Aborigines in a way."

Aamer could see that when encountered only as a representative of a group—“Arab, Muslim"- he didn't matter and was interchangeable with "homeless people" or "Aborigines." Emad expressed a similar concern. He complained that when he was in detention, the authorities made no attempt to discern any individuality, but that instead detainees were treated as just that.
Not all people are the same. Mentally, some of the people can cope with the circumstance there. Some of them, the majority of them-especially kids and women-cannot. So the management and the immigration didn't take into consideration that the people are different. They behaved in a one rough manner, one rough standard towards all of the people, and that's completely wrong. You're being tough to everyone. You have to understand every person's need-or try to understand. Even if you fail, try to understand. Try to take some effort to understand. That we couldn't see, we didn't see at all actually. We just saw some ... a very hard-line treatment and it was typical every day, every morning, every night. They didn't try to investigate what's in our hearts or mind. And we believed that humans can, actually can, reach to the hearts and minds of the other humans. But unfortunately it wasn't the case at that time.

Ibrahim also expressed frustration at the sameness of all detainees when he said, "It's wrong. But for us, we been just all same. Refugee or criminal or whatever-you the same. Like the children, women, anyone." He complained that any individual speech or action in detention had no impact on the way in which he or his fellow detainees were treated. He, and those detained with him, had been categorized as "unlawful entrants" and would be treated accordingly until re-categorized as "refugee." At heart, it was this bureaucratic dehumanization that the cry "We are human" struggled against and that refugee protest sought to counter.

\section{The Right to Have Rights}

Arendt conceived of human rights in two groups. Civic rights are "all those rights which require the protection of a government,"11 including all the rights contained in international human rights treaties such as the right to adequate food and shelter, the right to vote, to education, to freedom of movement, and so on. Prior to this group of rights however, is "the right to have rights," which she defined as the right to "a place in the world which makes opinions significant and actions effective." ${ }^{2}$ For Arendt this meant that meaningful speech and action, and plurality based on equality and distinction are necessary elements for a human life to be recognizable as such and to rise above mere survival.

Speech and action are fundamental dimensions of the human condition and distinguish us from other animals. If we are deprived of the opportunity to speak and act, and to engage with other human beings on a basis of equality, we are denied an essential aspect of our humanity. Speech and action become meaningful only when they are recognized by others, and this recognition constitutes and conveys our equality and our membership in the polis. Conversely, when our speech and actions are ignored by those around us, we
(C) Author(s), 2016. This open-access work is licensed under a Creative Commons Attribution-NonCommercial 4.0 International license.
Cette oeuvre en libre accès fait l'object d'une licence Creative Commons Attribution-NonCommercial 4.0 International. 
become a non-person and have no impact on the common world beyond the private sphere of personal relationships. It was precisely this non-existence that Farshid referred to when he said, "People's situation in detention was that you were the lost person, the forgotten person, you don't exist, you cannot change anything, and you have no power over anything."

Belonging to a political community and participating in the public life of that community is a fundamental aspect of the human condition. Humans are distinguished from gods and beasts by our capacity for action and our existence in plurality. Arendt argues that since Aristotle, humans have been "defined as ... commanding the power of speech and thought ... and as the 'political animal' ... one who lives in a community." ${ }^{3}$ Being a "political animal" is not the same as being a social animal, which requires individuals to live together for procreation or survival. Politics has an added existential depth and involves the capacity to organize and create a world of human affairs, the common world. It is this that distinguishes human life. ${ }^{14}$ Therefore, the loss of a political community means the loss of "some of the most essential characteristics of human life." 15

In order to understand how the loss of recognition in the public sphere equates to the loss of humanity, it is necessary to look in greater detail at two key aspects of Arendt's conception of the human condition; first, the human need for meaningful speech and action and, second, plurality, that consists of equality and distinction.

\section{Meaningful Speech and Action}

Arendt identifies meaningful speech and action as a necessary condition for a life that is "fully human" and enters the common world as an equal. It is through individual speech and action, recognized and judged by others, that each individual human being reveals her unique and distinct self to the world: "In acting and speaking, men show who they are, reveal actively their unique personal identities and thus make their appearance in the human world, while their physical identities appear without any activity of their own ... This disclosure of 'who' in contradistinction to 'what' somebody is-is implicit in everything somebody says and does. It can be hidden only in complete silence and perfect passivity."16

But a life of silence and passivity is, according to Arendt "dead to the world." Actively participating in public life is necessary for human life to be distinct from "mere bodily existence," and it is through meaningful engagement with others as equals that human life distinguishes itself. ${ }^{17}$ Ismail remarked that if he had not protested against the regimen of detention, but instead had silently and passively accepted his position, he would cease to be alive in any meaningful sense: "Because if I didn't do those things, nothing different between me and this table. With me? I got a soul. I got a mind. I got thinking."

Sayed expressed a similar opinion when he explained why he and others took action against detention: "That's what happens, that's the main purpose everybody do what they do. Otherwise there is no difference between the live and the dead you know. Otherwise I could be dead-nothing."

When someone's speech and action are not recognized, she is treated and judged, not according to who she is (through her words and deeds), but according to her membership in a category. This refusal to recognize someone's individuality is a refusal to recognize a fundamental aspect of her humanity and is profoundly dehumanizing. When Arendt speaks of the individual, it is not the pre-existing abstract autonomous individual of Enlightenment thought, upon which modern politics is based, but rather, she is referring to an ontologically intersubjective and interdependent individual. "The self for Arendt is the self of a human community that is formed through and cannot exist without interacting in the world." 18 The power of speech and action is not only a capacity for self-revelation, consisting of the disclosure of a pre-formed and complete self to a waiting world, but is simultaneously self-constituting. Humanity is fundamentally plural, and plurality is an inescapable and a desirable dimension of humanity.

\section{Plurality: Equality and Distinction}

Plurality, for Arendt, paradoxically consists of distinction and equality. Humans share certain essential characteristics, but unlike the potentially homogenizing force of universalist or essentialist arguments, Arendt's "human condition" is based on distinction, both of humans from other animals and of every human from every other human. "We are all the same, that is, human, in such a way that nobody is ever the same as anybody else who ever lived, lives, or will live."19 Every human is different and distinct, though we all share the capacity to initiate, to create, to think, to speak, and to act, and these capacities are core to human life. No two people are ever absolutely identical, and it is through the insertion of the individual self in the common or public world that each of us contributes to the human artifice, which constitutes the common world and ourselves at the same time. Plurality requires difference and multiplicity. A necessary tandem element of plurality is equality.

Equality, for Arendt, does not refer to the equal distribution of material goods, nor to an abstract equality inherent in the human condition, but equality as a political decision and as the basis for politics shaped by justice, rather than coercion or force: "We are not born equal; we become equal as members of a group on the strength of our decision to
(C) Author(s), 2016. This open-access work is licensed under a Creative Commons Attribution-NonCommercial 4.0 International license.
Cette oeuvre en libre accès fait l'object d'une licence Creative Commons Attribution-NonCommercial 4.0 International. 
guarantee ourselves mutually equal rights. Our political life rests on the assumption that we can produce equality through organisation, because man can act in and change and build a common world, together with his equals and only with his equals." ${ }^{20}$

Inequality and a lack of recognition of detainees' basic humanity shaped interactions between detainees and officials and was reinforced through every aspect of detention life. Food was raised as an issue by almost everyone interviewed. For Osman, the poor food was an issue of inequality. He complained to the detention manager and said, "The way you eat in your home, bring it to us." Most people expressed the lack of equality as a lack of respect. Ibrahim, when asked what he needed to feel human, responded, "To be respected as a human. To be treated as a human. So you can feel your humanity and dignity. It's very important. It's very simple too. That's what we were asking for, and unfortunately, we didn't find it. We found the opposite thing, which is they treated us as an animal, and maybe even the $\operatorname{dog}$... because the manager of the camp has a dog, and I think the dog, he was luckier than me. Seriously."

Arendt considered respect an essential foundation for politics that is based on mutual equality rather than force. She described respect as a public sphere sentiment that acts as a basis for human relationships, similar to the way in which love binds relationships in the private sphere: "Yet what love is in its own narrowly circumscribed sphere, respect is in the larger domain of human affairs. Respect, not unlike the Aristotelian philia politikē, is a kind of 'friendship' without intimacy and without closeness; it is a regard for the person from the distance which the space of the world puts between us, and in this regard is independent of qualities which we may admire or of achievements which we may highly esteem."21

In this light, the respect that Ibrahim and others said they needed in order to "feel human" can be understood as representing their equality and belonging. Because we are intersubjectively and interdependently constituted, a widespread lack of respect in the public sphere can easily lead to civic death, or what Farshid described as being "the lost person, the forgotten person, you don't exist." A refusal to be lost or forgotten, to accept their civic non-existence, regardless of material outcomes, was a major motivation in much detainee protest action.

\section{Detainee Protest as Restoration to a "Human" Status}

Refugee protest against detention sometimes achieved its stated aim, such as a mass hunger strike in January 2002 at Woomera. The Australian government suspended the processing of claims from Afghan applicants after the allied invasion of Afghanistan. The hunger strike was started by Afghan detainees, but people from other nationalities soon joined in. At its peak, detainees reported that 370 men, women, and children were on strike, and 70 sewed their lips. ${ }^{22}$ The strike lasted for sixteen days and called for a resumption of processing claims and an improvement in the conditions of detention. Woomera detention centre became difficult to run and attracted significant media attention. The government sent in negotiators and, after initially labelling the strike as "barbaric" and refusing to be "manipulated" by such behaviour, finally agreed to resume processing and improve conditions. ${ }^{23}$ Protests seldom achieved changes in government policies or actions and could be viewed as "failed" by some, but detainees overwhelmingly saw protest action as effective. For detainees, protest was aimed partly at external goals, but it also carried important restorative functions. It was a way to reject the powerless state of "detainee," to re-experience their agency, and to insist upon entry to the polis as political subjects rather than objects.

Especially after a protest, I would feel proud of myself. 'Cause I did something that every free man would do. You know? You are not dead body. You are human, you have got dream. So when you do those things and you come back to your room and think "Oh that was good." Even if we didn't achieve what we wanted, like talking with Immigration or bring Immigration to see us, but at least you feel like the things inside your chest come out. It's better than inside, you get sick. You feel a little bit open and relax, until the next action. (Osman)

Detention centres are extraordinarily controlled environments, where communication, food, activity, movement, and information are tightly regulated and monitored. Detainees have little opportunity to participate in decisionmaking, either at the mundane level of deciding what to eat, or in more fundamental matters such as education, work, or political status. Despite the unequal power relationship between the state and detainees, however, they were not entirely without power. Detainees had less political, material, and semiotic power than the state, but they retained human capacities for thought, speech, and action; they retained agency. Resistance was an important way for detainees to experience their own agency, to take a decision not to eat the food on offer, or to create a disturbance and force a response from authorities such as through self-harming or breaking a piece of camp infrastructure.

Detainees' bodies were a site for the exercise of state sovereignty, but also for detainees to reclaim sovereignty of self. Lacking power over their external environment, they sought to exercise power over their own bodies, and through this to influence their environment and regain a sense of self. Shahin explained the high incidence of hunger strike as a way of experiencing and expressing control over one's own body
(C) Author(s), 2016. This open-access work is licensed under a Creative Commons Attribution-NonCommercial 4.0 International license.
Cette oeuvre en libre accès fait l'object d'une licence Creative Commons Attribution-NonCommercial 4.0 International. 
and refusing the omnipotent power of the state: "This would happen because you have no choice. You can't make any decisions in your life. Just to show you are alive, you could make a decision to stop receiving anything in your body. That would show that you were alive, because you could make a decision, in a place that you can't make any decision."

Many former detainees interviewed in this research project had conducted hunger strikes, many of which had achieved the stated aims. Sayed was transferred to a prison when the detention centre became too full. He refused to eat or comply with the prison regime for several days before he was transferred back to detention. Many people said that the official mechanisms for getting anything not routinely provided simply didn't work. Baha'adin explained that if he had a headache and wanted paracetamol, he would be required to lodge a request form, which usually got no response or was granted several days later. He soon learned, as Sayed explained that "if you ask for the request-you don't get it, but if you shout and do something, break something up, you get all these things done." Compliance with the system was largely ineffective and gave people no sense of their own power.

The rates of self-harming are many times higher in detention than in asylum-seeker and refugee populations outside of detention, and it is understood as a sign of poor mental health. ${ }^{24}$ While some detainees also saw it this way, some explained that it was a way of experiencing one's agency. For Issaq, the need to be the initiator of an action and provoke a reaction could be met through cutting himself. His selfharming was an effort to make his actions meaningful.

I wanted to have something to look forward, then slash my wrists and see what's going to happen. You know what I mean? Just something out of ordinary. I mean I know that I'm sitting here and watching that tree, nothing going to happen. I won't get a visa, I won't get out of here and every day going to be the same. But I want to change it. The only power I have to just slash my wrists and see what's going to happen after it. Will it cause attention or not? Will it, you know? You'll hope for a change. To use all what you have to change-I mean, not to get out of detention, but change what's happening now. I mean, I'm sitting here, by doing nothing, nothing would change. But by slashing my wrists there are going to be some action at least. At least five officers are going to come out of the door, nurse is going to come, and all these things. Something going to happen out of ordinary, and in terms of self-harm that was the thing I was looking for. All the power that you have. That's all the power, not just a little of it. That's all you have.

When Issaq was compliant, he could be ignored, but when he self-harmed, the authorities must react. His apparently destructive self-harming paradoxically brought him closer to a place in the world in which his actions were meaningful.
Sam didn't self-harm during his three years in detention, but he was a trusted confidant of many fellow detainees and talked with many people who were self-harming. His explanation is similar to Issaq's, but with less concern for provoking an external reaction than an internal one. He said self-harm “in most cases wasn't a planned thing. It was in most cases out of frustration and it was good in a way that people feel they are real again, they exist, they have power over something-their body. So blood always has a very powerful message, and when people see they can get over their fear and do something, certain thing-harsh thing, they come back to that colour of existence-I have power, I can do things. So I was calling that self-actualization out of frustration in that situation."

The omnipotent power and control of the detention environment and the dehumanization of non-citizenship reached into every aspect of detainees' lives. Their daily routines were micromanaged to such an extent that people lost their sense of self. Protests ranging from breaking a light bulb through to self-harm, hunger strike, and riot were a way of re-experiencing oneself as an agent and of reclaiming human status.

\section{Insisting on a Place in the Polis}

Much detainee resistance was outwardly aimed, that is, there was a specific external target audience and/or goal that the protest sought to achieve. Most was targeted at achieving specific material changes such as getting a light bulb replaced in a room, gaining increased access to telephones, or securing the release of all detainees. These actions were directed primarily at those with explicit power over the detention environment: government officials and security guards. Other forms of resistance were aimed not at government or others directly involved in detention, but at the broader population seeking semiotic change, to effect their representations and position in Australian politics. The target audience of these protests was the Australian and international community (typically through the media, but also through refugee supporters outside), and the aim was to disrupt and unsettle government accounts of their presence in Australia and their actions in detention, and to insert their own narrative alongside their own actions. Detainee protest marked a refusal to allow official government or bureaucratic explanations of their presence and actions to go unchallenged and to insist on active, conscious participation in the political debate.

Detainees saw that they were being used as pawns in Australia's national politics, in particular, that there was political capital for the government in their suffering, and that their suffering was intended to be public and to deter prospective asylum seekers overseas. Ibrahim believed that
(C) Author(s), 2016. This open-access work is licensed under a Creative Commons Attribution-NonCommercial 4.0 International license.
Cette oeuvre en libre accès fait l'object d'une licence Creative Commons Attribution-NonCommercial 4.0 International. 
detention was "a plan to punish these people to be honest. This plan has been well managed by someone with high authority in the hierarchy to punish these people and to make them a good example for others ... people are gonna think twice before they come to here." Mehdi reached a similar conclusion: "We were the victim of Australian policy to just stop people coming illegally or something. We were the victim and they wanted to show people that we keep them ... It's not a matter of 'What's your story or what ...?" It's just 'Keep that person.' That's it. They needed to keep some people ... for a long time to say that 'We are strong against these people."”

Emad agreed and added that the theatre of detention gave material proof of the government's strength and resolve to protect Australia's borders and that this was a deliberate strategy to retain government.

Their intention was to give a real strong lesson to the outer world not to come to Australia, oK, by restraining us a group. It's just a misfortunate incident, bad timing for us. Someone wants to give a lesson to the whole world through us. They wanted to say, "If you come to Australia that will be your destiny. You will be treated like this." So, we are subjected to a political, not legal, pressure-a political pressure that the government, at that time, needed to get votes from the ordinary Australian people. And that's what I think happened. In reality one of the main aspects for John Howard election-and he won the election at that time-is that he used immigration as a pressure point, as an element in his campaign to defeat Labor. So we were the source of this election campaign ... Unfortunately they didn't look at us as humans in need for their help. They looked at us as a human that they can use in their election to win and to prevail. And I think that's completely wrong. (Emphasis added)

This analysis is important, because once people had determined that their fate rested not on an individual assessment of each person's claims, but on national political interests, detainees lost faith in the official systems and began to consider alternate actions to resolve their situation. Detainees realized that they needed to establish a political voice for themselves, and reaching the media became a major focus of protest action. There was considerable debate among detainees about how to do this. Many feared that violent protests would reinforce the government representation of them as "uncivilized," a people to be feared, and the perception that their detention was necessary to protect Australia from dangerous people. Many others believed that non-violent protests would go unnoticed. As Issaq argued,

Peacefully doesn't answer anything because there is no journos here. We need to get journos here, and how we can do it? Just go to a town and sit in there until journos gets here? Or just burn the place down and the smoke will bring journalists, you know? That became the main point, just to get the journalists coming there, to make a scene, have a story for a TV or radio or newspaper ... for journalists to fly in there and see us, because they had to come from Adelaide, and it was like 5ook away. So they needed a good story. People sewing their lips in detention was a good story or people burning down the centres was a good story, even though it was relative. But it was getting into a media ... We didn't care about negative publicity. We just wanted to get people to come to detentions and sit.

Dr. Aamer Sultan was initially opposed to hunger strikes, lip-sewing, and violent protests and did not participate in any of these actions during his three years in detention. But looking back, he was less resolute in his objection. He said that he was "very unhappy" about how "the media had shown those aggressive criminals" but that in hindsight

it was a positive thing ... At last the government did the mistake of transferring the camera into there, let the people know at least there are some people there. I mean it's just the beginning of questioning "Who are those people? We don't know about them. We worry about them. Criminals or not, even the most dangerous people in the world, or maybe the other way around, we just want know about it." It's just the fact that this has transferred the argument from a faceless people into actual people doing something bad or good, it doesn't matter.

Most actions were targeted not at government officials or detention centre guards. They were aimed to achieve semiotic change, to insist on a political voice for detainees a place in the polis. Detainees wanted to speak directly to "fellow human beings." After his release, Shahin urged people he met to "write letters to people in detention centres. Get in touch. There is a wall the government has created. And this wall needs to be chipped away from both ways. People from inside are doing their way, for you really the best way is to get to know them. As long as that wall is there, the government can do what they want. And once it is broken or has holes in it, then it's very hard." He was convinced that with direct communication "people could see a human face behind the kind of stories that they had heard or they had seen on the TV. It was very different to be that close."

Shahin's comments reveal an Arendtian understanding of the political sphere, a common space in which people can develop and test their opinions with one another on an equal basis, where membership is confirmed not through formal citizenship, but through recognition of one another displayed through engagement with one another's words and deeds. This kind of encounter draws on conceptions of
(C) Author(s), 2016. This open-access work is licensed under a Creative Commons Attribution-NonCommercial 4.0 International license.
Cette oeuvre en libre accès fait l'object d'une licence Creative Commons Attribution-NonCommercial 4.0 International. 
politics in ancient Greece, not as the formal mechanisms of state, nor as the technocratic organization of work, but as a realm in which individual, mutually constituted human beings come together and build a common world. Politics is the arena through which humans present themselves to the world qua human, the space for "appearance" as equal and distinct individuals.

Formal political mechanisms of state are based on representational politics, and asylum seekers had no representative in this realm. They astutely reached out to people outside detention as "fellow human beings." Mohammed explained, "The problem was because we saw a lot of things. Government accuse us, abuse us, and a lot in the TV, and we want to tell 'We are here, we are human beings, we're not more than anything, just we are same as you.'” Issaq hoped that the protests would open a space in which he and other detainees could "just reflect our feelings to another human being, just to see us not as a danger but as another human being who escaped from danger."

\section{Detainee Action to Create an Alternative Polis}

Asylum seekers in detention recognized that gaining entry to the formal Australian polis would likely take several years, but the need to belong to a community in which one's speech and action is meaningful, in which one's equality and dignity is recognized, is ever-present. Asylum seekers formed their own political communities inside the detention network. These smaller groups could not ensure people's civic rights in the manner of a nation-state, but they nonetheless established a basis for protecting individual human dignity and exercising human capacities. Through protest, asylum seekers were able to experience their own agency and offer support and recognition to one another. Sayed explained that protest gave him a sense of confidence and agency:

You gain self-confidence because in the environment you are in you are depending for everything and you abide by the rules, so you have to do like they tell you to do. They set the time for food, you don't have control on anything. When we do something like that, ... it's like a self-independence type of thing. That's what happens. That's why we protest like, because you are achieving something, even though you're not, in the short term, yes you are, but in the long run you won't, but still you will say, you will gain the self-confidence.

Inside detention, detainees discussed and analyzed their situation, their place within Australian politics, the ethics and efficacy of different actions, and ways to speak directly to the Australian public. These communities extended beyond individual relationships and individual detention centres, and across linguistic, religious, and ethnic divides. Within these communities, detainees addressed each other by name, and their opinions were made significant, at least at a very local level through a shared sense of solidarity and belonging. These political communities reassured detainees that they mattered: "A lot of things for other people we done as well to show the support to other things, people that look out at you, 'You are not alone, don't kill yourself. We help you out. We try to help you as well.' Yeah, plenty of things ... They were doing it as well for me too" (Baha'adin).

Emad saw this interconnectedness not only as situational interpersonal care, which is a matter of the private realm, but as fundamental to politics based on mutual respect and recognition, and to the human condition: "So we all try in this world to do something better, because I can't live this life by myself without seeing you smile in this world, because I'll be frustrated at that time. You know, I want to live with other humans who are happy. And I want to see them, you know, achieve their goals in this life."

\section{Conclusion}

Detainees pleaded for recognition as fellow human beings. As Emad put it, "I'm not a perfectionist, I'm not calling for 100 per cent. I need the minimum when someone treats me as a human, not like an object inside the detention centre." Detainees sought to restore their rights by gaining formal entry to the Australian political community through formal refugee applications and through protest. In parallel to using rights-based institutional mechanisms for restoration of the right to have rights, detainees drew on moral and philosophical discourse of human rights, centring on the "human." To be stripped of rights is no distant or academic experience, it is intensely intimate, at once both personal and political. The protests and actions of refugees in detention were aimed at "us," actual people. They were intended to trigger a sentimental, human response and so to insert themselves into the polis, in the absence of bureaucratic recognition, through human-to-human recognition. Arendt's model of human rights as arising only from human determination carries with it the realization that "we" have the power to affect human rights and to decide who falls within the mutual guarantee. Detainees demonstrated their understanding of this view and pushed for recognition by the Australian community beyond the legal and bureaucratic systems. Detainees may be granted a visa and with it, certain legal rights based on re-categorization as a "refugee," but achieving the sort of human rights that Arendt speaks of, of belonging, equality, and distinction relies on deeper political (in the ancient Greek sense) recognition. Shahin expressed it beautifully:
(C) Author(s), 2016. This open-access work is licensed under a Creative Commons Attribution-NonCommercial 4.0 International license.
Cette oeuvre en libre accès fait l'object d'une licence Creative Commons Attribution-NonCommercial 4.0 International. 
It is a massive thing to live with the title of "refugee." Which is something that you are bestowed on, you didn't choose it, you didn't pick it. You thought you are making a freedom of movement to get out of a problem that you are in, and now you are in another type of trouble, and there is a title for you to carry on. It is very understandable that a lot of people don't want to be called by that title, and as soon as you go out, that's the first thing that you get. Not many of us feel comfortable with that, but some of us feel like, I don't know, I would like to ... this is something that is on me now. I would like to define it the way that I fulfill it. So yes, I'm a refugee, I'm from Iran, but I'm a human being with these passions, these emotions, this laughter, and these crying moments. You know, like any other human being. And that is the way that I am that refugee.

Lucy Fiske is a Chancellor's Postdoctoral Fellow in the Faculty of Arts and Social Sciences, University of Technology Sydney. The author may be contacted atLucy.Fiske@uts.edu.au.

\section{Notes}

1 The International Detention Coalition maintains an up-todate database of locations, conditions, and populations of immigration detention regimes globally. Further information can be found at idcoalition.org/detention-database/.

2 The conditions of Australian detention centres have been well documented. For more detail see, for example, Australian Human Rights Commission, The Forgotten Children: National Inquiry into Children in Immigration Detention (Sydney: Australian Human Rights Commission, 2014); Linda Briskman, Susie Latham, and Chris Goddard, Human Rights Overboard: Seeking Asylum in Australia (Melbourne: Scribe Publications, 2008); Lucy Fiske, "Riotous Refugees or Systemic Injustice? A Sociological Examination of Riots in Australian Immigration Detention Centres," Journal of Refugee Studies 27, no. 3 (2013): 382-402; United Nations Working Group on Arbitrary Detention, Civil and Political Rights, Including the Question of Torture and Detention: Report of the Working Group on Arbitrary Detention. Visit to Australia, document E/CN.4/2003/8/ Add.2 (Geneva: United Nations Commission on Human Rights 59th Session, October 24, 2002).

3 See, for example, Michael Clyne, "Words Excusing Exclusion," in Seeking Asylum in Australia 1995-2005: Experiences and policies, ed. Susan Aykut and Jessie Taylor, 21-8 (Melbourne: Monash University Institute for Public History, 2006); Department of Immigration and Multicultural and Indigenous Affairs, "Arson at Woomera Detention Facility," news release, 18 December 2001; Department of Immigration and Multicultural and Indigenous Affairs, "Woomera Officers Targeted in Orchestrated Attack," news release, 31 December 2002.

4 Semi-structured interviews were conducted with eighteen former detainees in 2008 and 2009 in Perth, Sydney, and
Melbourne, Australia. Respondents had been detained between 1999 and 2005 for eight months to five years, with the majority having been detained for more than two years. Although this was a qualitative research project, there was a definite link between the length of detention and the number and types of protest actions engaged in. Most interviews were conducted individually, with one focus group and two pairs. Interviews typically lasted 90-120 minutes and began with an open-ended question: "Describe a typical day in detention." The interviewer then probed for more detail, depending on the responses of participants. Participants originated from Afghanistan, Iran, Iraq, and Jordan, and one was a stateless person. All respondents were men. The people interviewed in this research were all detained as asylum seekers, and all except one had been granted refugee status. I use the terms refugee and detainee throughout, as it was their status as detainees that underpinned much protest, rather than their status as refugees. The research is published in full in Lucy Fiske, Human Rights, Refugee Protest and Immigration Detention (London: Palgrave Macmillan, 2016).

5 The research presented here used inductive analysisstarting with the explanations of refugees subjected to immigration detention, and using this to direct my search for theoretical and analytical frames. Hannah Arendt's work on human rights and her thoughts on "the human condition" resonated with much of what was said by the people interviewed for this research. While Arendt's work has at times been criticized for drawing too neat a distinction between the public and private realm, her work, particularly with its emphasis on a constructivist approach to human rights and her insistence that actual human beings remain at the centre of human rights (rather than nature, an abstract man, or legal/bureaucratic categories) that makes her work so useful in understanding the language of human rights used by asylum seekers in detention. For more on Arendt's approach to human rights and critiques of her work, see, for example, Seyla Benhabib, "Feminist Theory and Hannah Arendt's Concept of Public Space," History of the Human Sciences 6, no. 2 (1993): 97-114; Lewis P. Hinchman and Sandra K. Hinchman, Hannah Arendt: Critical Essays (Albany: State University of New York Press, 1994); Serena Parekh, Hannah Arendt and the Challenge of Modernity: A Phenomenology of Human Rights (New York: Routledge, 2008).

6 The dehumanization of immigration detention has not been the subject of extensive academic attention. Studies that have explored it include Guy Coffey, Ida Kaplan, Robyn Sampson, and Maria Tucci, "The Meaning and Mental Health Consequences of Long-Term Immigration Detention for People Seeking Asylum," Social Science and Medicine 70 (2013): 2070-9; Daniela DeBono, "Less than Human: The Detention of Irregular Immigrants in Malta," Race and Class 55, no. 2 (2013): 60-81.
(C) Author(s), 2016. This open-access work is licensed under a Creative Commons Attribution-NonCommercial 4.0 International license.
Cette oeuvre en libre accès fait l'object d'une licence Creative Commons Attribution-NonCommercial 4.0 International. 
7 Pseudonyms have been used to protect informants' identity, except for Aamer, Farshid, and Shahin, who have all spoken publicly of their experiences in detention and have consented to using their real names. And I have chosen to reproduce the exact syntax and grammar of the speakers in the quoted text.

8 Hannah Arendt, The Human Condition (Chicago: University of Chicago Press, 1958), 179.

9 Boatperson is a term used in Australia to refer to asylum seekers who have arrived in Australia by boat without prior authorization. It has some derogatory connotations, particularly in casting such people as morally dubious and untrustworthy. Boatpeople are subject to legal frameworks and policies that are different from those for asylum seekers arriving by plane. There are movements underway to reclaim the term boatpeople as "genuine" refugees and to counter the pejorative use of the term.

10 Hannah Arendt, The Origins of Totalitarianism (Orlando, FL: Harcourt Publishing, 1976), 301-2.

11 Serena Parekh, "A Meaningful Place in the World: Hannah Arendt on the Nature of Human Rights," Journal of Human Rights 3, no. 1 (2004): 41.
12 Arendt, Origins, 296.

13 Ibid., 297.

14 Arendt, Human, 22-5.

15 Arendt, Origins, 297.

16 Arendt, Human, 179.

17 Ibid., 176.

18 Benhabib cited in Parekh, "Meaningful Place," 52.

19 Arendt, Human, 8.

20 Arendt, Origins, 301.

21 Arendt, Human, 243.

22 Anne Barker, "Afghan Youths Threaten Suicide at the Woomera Detention Centre," 7.30 Report, ABC Television, 28 January, 2002, http://www.abc.net.au/7.30/content/2002/s468052.htm.

23 Natascha Klocker and Kevin Dunn, "Who's Driving the Asylum Seeker Debate? Newspaper and Government Representations of Asylum Seekers," Media International Australia 109 (2003): 71-92.

24 Commonwealth Ombudsman (Australia), Suicide and Self-Harm in the Immigration Detention Network, report no. 2/2013 (Canberra: Commonwealth Ombudsman, 2013). 


\title{
Narrating "Home": Experiences of German Expellees after the Second World War
}

\author{
VANESSA HUGHES
}

\section{Abstract}

This article explores the experiences of forced displacement through the narratives of expellees in Germany after the Second World War. It considers how disruptions of "home" over time and space have led to constant deconstructing and reconstructing of home. Based on autobiographical interviews, this article argues that home is multidimensional and contradictory, changing over time and through experiences, becoming simultaneously connected to a specific place and time while transcending this rootedness. This continuous contestation of home has led expellees to form an imagined, idealized, and romanticized notion of their Heimat that exists in memory and is combined with their current home, Zuhause.

\section{Résumé}

Cet article étudie les expériences de déplacement forcé à travers les récits des expulsés en Allemagne à la suite de la Deuxième Guerre mondiale. Il considère le processus par lequel les perturbations dans l'idée d'un "chez-soi" dans le temps et l'espace ont mené à une déconstruction et reconstruction constante de cette notion. En se basant sur des entrevues autobiographiques, cet article avance que l'idée de "chez-soi» est multidimensionnelle et contradictoire, se transformant à travers le temps et les expériences, s'attachant à un lieu et temps particulier et en même temps évoluant au-delà de cet enracinement. Cette contestation continuelle de l'idée de "chez-soi» a mené les expulsés à former une notion imaginée, idéalisée et romantique de leur Heimat qui existe dans la mémoire et qui est conjuguée avec l'idée de leur Zuhause, leur chez-soi actuel.

\section{Introduction}

There were twelve million German refugees and expellees in Germany after the Second World War. This was one of the biggest movements of people in Europe's recent history, yet little is known about how individuals experienced it. ${ }^{1}$

In this article my aim is to explore how expellees experienced their expulsion and subsequent repatriation, and how this influenced their understanding of "home." Following Malkki, I will examine their experiences to "question the notion of identity as a historical essence rooted in particular places, or as a fixed and identifiable position in a universalizing taxonomic order."2 Broadly speaking, their common experience was an expulsion from their childhood home and being placed in a "home by chance." 3 Disruptions of "home" forced them to continuously negotiate meanings of home, both materially and symbolically.

Among the narratives in this research three main chronological phases of "home" emerged. The first is dominated by a sense of "loss," the second phase by "itinerancy," and the final phase is "settlement." These three phases will be explored in this article.

These experiences of "home" contributed to a distinct construction of what "home" means to expellees. Previous studies on this topic found that expellees make a clear distinction between Zuhause (at home) and Heimat (homeland), ${ }^{4}$ where ties to the "homeland" are maintained, and the new home is only reluctantly accepted. 5 Such discourses are present in personal and collective narratives. 6 "Home" here is a multidimensional concept, which includes personal and social aspects as well as physical, emotional, material, and symbolic meanings. Furthermore, "home" can be contradictory and ambivalent, fixed and yet without boundaries. ${ }^{7}$

By analyzing the three phases of "home" in the narratives of expellees, my aim is to understand what "home" and
(C) Author(s), 2016. This open-access work is licensed under a Creative Commons Attribution-NonCommercial 4.0 International license.
Cette oeuvre en libre accès fait l'object d'une licence Creative Commons Attribution-NonCommercial 4.0 International. 
"homeland" means to them, how these phases have influenced expellees' construction of "home," and to what extent recent theories can explain these constructions. In this article I will first discuss the concept of home and the historical context of this article. I will then explore the three phases of "home" as narrated by the expellees and finally evaluate how they contribute to a conceptualization of "home"-in short how displacement, deterritorialization, and exile shape the construction of "home."

\section{What Is the Meaning of "Home"?}

Conceptualizing home is complex. Traditionally home was viewed as fixed and bounded, linked to the assumption of a natural association between people, culture, and territory, ${ }^{8}$ connected with feelings of security, familiarity, and privacy, and gendered as female, rather than the (male) public sphere. More recently, interdisciplinary, feminist, and transnational approaches have challenged this notion of home. This included decoupling the private sphere from naturally being gendered as female, disassociating home from its physical locality, deconstructing its identity-place unity, and thus exposing its social and cultural construction. ${ }^{9}$ For example, in her study of elderly Bengalis in London, Gardner found that their understanding of home is "fluid: a set of practices, memories and myths." ${ }^{\circ}$ The meaning of home to an individual can thus change according to gender and stage in the life-course, and depends on cultural, historical, economic, and political context. ${ }^{11}$ Furthermore, home is a concept that is culturally and ideologically influenced, inscribed with personal meanings and emotions. ${ }^{12}$ Given that in migration or displacement, contextual factors and the material dwelling change, this becomes an appropriate site in which to study "home."

Important contributions to this field and relevant to this article have emerged from anthropologists working on transnationalism. ${ }^{13}$ In their Migrants of Identity, Rapport and Dawson call "for the anthropological appreciation of 'home' as a useful analytical construct" to "explore physical and cognitive movement within and between homes, and the relations between the two," incorporating perspectives of both the individual and the collective. ${ }^{14}$

According to Rapport and Dawson, the traditional fixed meaning of home discussed earlier is no longer useful in a world defined by mobility. Home has become mobile and "plurilocal," intricately bound up with movement, and can be defined as "where one best knows oneself."15 It also has the strongest effect in its absence or negation, as in the case of migration or displacement.

In more recent transnational ethnographic work, scholars have explored the idea of having more than one home. ${ }^{16}$ Fog Olwig explains, "In the first sense, home is a concrete locus of specific relations of social and economic rights and obligations ... in the second sense, home is a more abstract entity of belonging expressed through various types of narratives and other forms of symbolic interchange." These two understandings and practices of home "mutually reinforce and implicate one another."17 Mand similarly argues that home is a lived experience and a place of origin. ${ }^{18}$ It is this idea of two homes that I will explore here.

\section{Historical Context: Expellees and Refugees in Germany after the Second World War}

The mass displacement of people that followed the end of the Second World War was the birth of the refugee. ${ }^{19}$ Discussions about "refugees" and "displacement" have numerous underlying assumptions. Two major premises are "that refugees are a transitory phenomenon of crisis and disorder, and thus only temporarily relevant ... [and that] human nature is best served in a sedentary setting." ${ }^{20}$ The term displacement itself assumes a natural association between people and place that is being disrupted. ${ }^{21}$ In this politics of space the "essential refugee" must have crossed a national border.

The end of the Second World War saw one of the biggest forced movements of people in recent history, where "some 15.4 million people had to leave their former home"22 and move from Eastern to Western Europe. This was as a result of the newly drawn borders in postwar Europe which were agreed at the Yalta and Potsdam conferences. Germany lost significant territory to Poland, thus having to resettle its citizens within the new national boundaries. The borders of the four Occupation Zones were also agreed at these conferences, eventually leading to the West and East Germany split.

The largest of these movements was that of ethnic Germans to the four Occupation Zones in Germany. ${ }^{23}$ The expellees came mainly from Silesia, Pomerania, Sudetenland, and East Prussia in Eastern and Central Europe. Further movements occurred across other boundaries in Central and Eastern Europe-often overlapping-and there were large numbers of other displaced persons as well, ${ }^{24}$ such as ex-prisoners of war and German ex-soldiers. The proportion of people moving was significant, and refugees made up 16.2 per cent of the population of Germany in 1950. ${ }^{25}$

\section{Methodology}

The narrative and autobiographical approach was chosen for this research, because of participants' age and stage in life (elderly, recollecting experiences of fifty years ago). Furthermore, given the lack of visibility of this topic, this method is appropriate when writing about "history from below," highlighting experiences that have featured little in mainstream
(C) Author(s), 2016. This open-access work is licensed under a Creative Commons Attribution-NonCommercial 4.0 International license.
Cette oeuvre en libre accès fait l'object d'une licence Creative Commons Attribution-NonCommercial 4.0 International. 
narratives. ${ }^{26}$ Finally, as Ahmadi Lewin argues, "Personal experiences are crucial for understanding how people perceive the meaning of home," thus the methodology used needs to be able to capture them. ${ }^{27}$

It has been argued ${ }^{28}$ that the strengths of the narrative approach lie in its ability to capture complexity and subjectivity, and to contextualize the individual's story. Importantly, this approach attempts to reveal the complexities of the individual's experiences as embedded in the broader context. As Abu-Lughod has argued, "Attending to the particulars of individuals' lives need not imply disregard for forces and dynamics that are not locally based, the effects of extra local or long-term processes are always manifested locally and specifically." ${ }^{29}$ These narratives are also "conscious and structured accounts of events across the past" 30 and reflect only what the expellees chose to tell me, thus generalizability is limited. While cultural positioning and narrative-construction biases cannot be eliminated, I tried to be constantly reflective and aware, to the extent possible, of the constructions and representations at play. Despite a small number of participants $(N=7)$, the qualitative and in-depth nature of narrative interviews can still provide useful insights into the social life of participants and how a particular historical event is remembered and was a real lived experience, revealing it also as a mundane and everyday experience. The aim is not representativeness but a deep understanding of dynamics and people.

While focusing in this article on the micro-level of individuals' experiences, it does so in the context of people's specific situated-ness in their political-economic and historical context, structural features, and policies. The aim is then to "understand one person's life and its meaning to that person in the context of broader history and culture" and to see what historical events of migration actually "look like on the ground," remaining "mindful both to the general and the particular."31

The interviews were carried out in Germany in July 2012 as part of a postgraduate research project. Participants were found through personal networks and the Alliance of Expellees Bremen. All but one of the interviews were carried out in the participants' own homes and lasted between one and four hours. Two interviews were carried out with two participants present, at their request. This arrangement is likely to have affected the narratives, on the one hand as memory aids, on the other by not broaching certain sensitive topics, such as marriage or childbirth in the case of the brother and sister. Being bilingual in German and English, I conducted the interviews in German. They were also recorded and transcribed verbatim. Pseudonyms were used throughout to protect participants' identity. The analysis was carried out on German transcripts, using a grounded theory approach.

The majority of participants welcomed me and were forthcoming in sharing their life stories. However, some were reticent to revisit their past, often a painful memory. Their hesitancy was usually be expressed with silence, and in these instances I refrained from pressing for further information, reiterating to participants that they did not have to tell me things they did not want to, and that they could withdraw from the study at any point.

In addition to the interviews, I visited local archives in Diepholz and in Bremen, to gain a better historical understanding.

\section{The First Phase: Loss of "Home"}

The loss of the childhood and family "home" was a traumatic experience for expellees, and with it "the sense of belonging to a place and community [was] brutally disrupted." 32 Their narratives kept returning to this event. What effect did the loss have on their understanding of "home"? How does this past "home" influence the construction of "home" today?

Renate illustrates the strong feelings this memory provokes: "When I think of it today ... this anger, this extreme disappointment, it sits so deep, I think I will take these feelings to the grave with me ... You see, we did not just lose our house ... we lost our Heimat. You know, everything can be replaced, but not the Heimat."

The first movement west occurred during the war, fleeing from the advancing Soviet army. Often these first refugees had relatives in the West-both Julia and Renate made their way west in this way. Others returned to their homes after the front had passed them. This was the situation for Erhard, Herbert, Helga, and Maria. Returning home after this short flight was coloured in contradictory feelings: relief that their house was still there coexisted with the sadness at its damage.

Soon the situation changed again. Herbert und Helga were eleven and nine when they saw a lorry pull into their farmyard bringing two Polish families to live with them in their home, which already housed a family of five.

Already at this stage the expellees' understanding of "home" changed. First, there was the experience of the sudden loss of their physical home, their material possessions, and their labour on the fields. This was followed by the reappropriation of the home. However, after the return, "home" no longer had the same meaning, as the sense of security previously bound up with it was lost. The home, although in the exact same place, was now marked by the scars of the war. The visible damage to the house and the field was a constant reminder of the fragility of the home.
(C) Author(s), 2016. This open-access work is licensed under a Creative Commons Attribution-NonCommercial 4.0 International license.
Cette oeuvre en libre accès fait l'object d'une licence Creative Commons Attribution-NonCommercial 4.0 International. 
The familiar village environment and everyday life had also been disrupted.

The arrival of Polish families means that the family home had to be shared. This again exposed the home as an unsafe and unfamiliar place. The home, which had been a private space, had to be given over almost entirely to strangers with whom they did not even share a language. The context of the war meant that, in the space of the home, a microcosm representing the postwar positions of "the Germans"-the losers-and "the Polish"-the winners-was being recreated. The result was a delicate balance that ensured survival for all members of the household, all who as a consequence of the war were losers of their own homes.

This period ended abruptly for most families as they were ordered to permanently leave between 1945 and 1947. They were told to pack their bags and go, destination unknown: "When we were leaving the village a little boy asked his grandfather, 'Where are we going?' and his grandfather answered, "If only I knew"” (Erhard).

Few realized that they would never return to their homeland, as illustrated by the fact that many buried their valuables before leaving. They were taken to a camp for medical screenings and delousing and then to their new "home." However, their final home still lay years away.

A consequence of the expulsion was the dispersal of families and village communities, representing the loss of another aspect of "home." In the homeland, families and neighbours depended on each other in their everyday life. Hermine tells of how they used to take their bread and cake to the bakery to be baked. And Maria writes in her memoirs, "We hadn't thought of the fact that we wouldn't be among the people we loved, once we had crossed the Neisse River. Where was Grandmother, Aunt Marta, the neighbours from home?" "They were deprived of the support networks they had relied on in their homeland," 33 which constituted a significant part of what "home" meant to expellees. It is then a loss of home in its multidimensional aspects-house, family, and social relationships.

In the movement of people from East to West, "the refugee camp became emplaced as a standardized, generalizable technology of power in the management of mass displacement."34 It was not only the organization of people in the camps but also the German bureaucracy and new laws 35 that created the category of the "refugee" and later "expellee." As Malkki puts it, "The refugee' as a specific social category and legal problem of global dimensions did not exist in its full modern form before this period." 36 Lehmann similarly observes that the fate of the refugee was seen as homogenous and uniform, when in reality the differences were more than the similarities. ${ }^{37}$ Such generalization and homogenization demonstrates a language of power that essentializes.
The term refugee was not the only categorization. With the realization that the "refugee problem" was not temporary and the German expellees and refugees had to be fully integrated in the Federal Republic of Germany (FRG), the term expellee emerged, illustrating the transition of their status to permanent members of the FRG. ${ }^{38}$

From these legal categorizations developed a collective identity of an otherwise diverse group of people bound together by their status as refugee/expellee and their common experiences of loss and suffering. It is this collective suffering, Svašek and Wolff argue, that is an important source of identification, individually and collectively. ${ }^{39}$

The terminology employed by the bureaucracy, the rhetoric used by expellee organizations and expellees themselves, entrenched the experiences of loss and suffering in their collective and individual identities, and thus became key to their understanding of home.

The meaning of home underwent profound changes as a result of disruptions during this phase of loss. Home as a locally bounded place of security and familiarity was fundamentally undermined by the traumatic uprooting of people from their material and territorial home. Sharing homes with the Poles represented a shift from understanding the home as private to public. With these deep disruptions to expellees' understandings of home, how was home reinscribed with meaning?

\section{The Second Phase: Itinerancy and Surviving in the "Home" of Others}

After damage to many of Germany's towns and cities during the war and the consequent housing shortage, expellees were located mostly to the countryside, where many "had to endure deplorable housing conditions." 40 The destinations of expellees were usually set arbitrarily, and "the task of integrating almost 8 million dispossessed refugees into an economy still recovering from the impact of the war was enormous." 41

Most arrangements for the accommodation of expellees were made locally. After the journey in the refugee mass transports, they were commonly placed in temporary shelters until they were "billeted with private householders." 42 The housing conditions and length of time spent in these "temporary" arrangements varied and led to serious overcrowding. Throughout this period refugee living conditions were significantly worse than those of the indigenous inhabitants. ${ }^{43}$ As Herbert and Helga described the first accommodation they stayed in together with their parents, "The room we stayed in was just a small booth ... It was one room with just one bed in it, an oven, a round iron stove, for all four of us."

Among my interviewees the length of time spent in such housing arrangements varied from a few years to a decade.
(C) Author(s), 2016. This open-access work is licensed under a Creative Commons Attribution-NonCommercial 4.0 International license.
Cette oeuvre en libre accès fait l'object d'une licence Creative Commons Attribution-NonCommercial 4.0 International. 
The housing shortage continued for a long time, with a shortage of 4.4 million homes in 1950.44

The experiences of the expellees I spoke to were typical of this period and deeply affected their understanding of home. The lack of privacy as subtenants was one major influence. Helga tells how their living space was constantly being "invaded" by their hosts: "When they, the farmers, opened the door to the entrance hall, we got completely smoked out!" Herbert did not even share the room with his family, instead he slept "in the entrance hall, where they put up an old bed for me to kip in, together with the farm hand." Hermine recalls a similar situation when they were subtenants with one small child: "As a baby she was all black in the face ... when ... [the landlords] were building the chimney and the wind came up, all the soot blew ... those are times you don't like to be reminded of."

Such conditions and multiple, frequent changes of "home" led to "home" being little more than a physical, practical arrangement. This "home" comes nearly without privacy, familiarity, or security-or these "homes" have none of the characteristics that the home in the Heimat had. Home then was starting to be constructed with reference to the absent Heimat, which also became idealized and romanticized.

Such an idealization of the homeland is common in migration and displacement. 45 In her study of Sudeten Germans, Svašek found that "Heimat was used to express Romantic notions of unspoiled life in the countryside" and explains that "selective memory is inherent in the notion of Heimat itself," erasing any problems and anomalies. ${ }^{46}$ Cordell found similar notions in his research, leading to difficulties in coming to term with the present. ${ }^{47}$ As Lovell argues, "memory recovers time and space in a synchronic gesture, streamlining and unifying some of its diversity and contradictions in order to create viable and cohesive collective images in the present." 48

Another pattern typical of the early postwar period was the separation of families through housing and work arrangements, in addition to dispersal created by the war and expulsion. The experience of Herbert and Helga's family offers an illustration. Their eldest brother, sixteenyear-old Michael, was immediately placed as a farm hand, and he lived where he worked. Once Herbert left school, he also moved out of his parents' sublet room to wherever he worked. On turning fourteen, Helga was "shipped to work in a hospital in Dortmund," also working for room and fare. Here, the dwelling of home is further disassociated from familiarity and security as the expellees' closest social relationships are removed from the space of the home. Home shifts from being an actual, bounded space to being de-localized relationships spread over significant physical distances.
Relations with locals also affected the way expellees understood home. These were often tense mainly as the result of economic discrepancies, such as in housing: "There is general agreement that housing was the most divisive economic issue between the newcomers and the original population." 49 Food was another cause, as is vividly recalled by Helga: "I will never forget how we were scolded by a local farm lady when we were stealing potatoes." It was particularly in rural areas that relations were difficult, "partly [as] the result of the huge economic and social gulf between the native and refugee populations. Many of the villages to which the refugees were sent in 1945-46 had emerged virtually unscathed from the war ... On the other hand, the refugees had to rebuild their lives from scratch. They had lost their homelands and most of their possessions." 50 This economic gulf is illustrated by a story from Herbert: "When I was staying with the farmer, we both got the same suit, a tailor in a nearby village made them. We both had the same suit, the only difference was that the farmer wore his for work and I only on Sunday afternoons. But I also had a suit!"

This time was narrated as a life of hardships and suffering, leading to feelings of inferiority and victimization among many expellees, strengthening the pillar of the collective identity developed through the loss of the home.

Finally, the view that the "refugee problem" was temporary caused tension. For some it became certain that they would never be able to return to their homeland only when Chancellor Kohl recognized the Oder-Neisse line as the German-Polish border in October 1990.51

These now semi-permanent arrangements reaffirmed the loss of home and second-class status among expellees. The space that was their "home" was often a space in the middle of another's home, constantly invaded by the host family. Whether relations were good or bad between the local family and the expellees, the negation of what home used to mean during this period entrenched the home in the Heimat as the ideal.

Even Renate, who managed to secure a private living space in a barrack with her mother and sister, expressed feelings of estrangement and inferiority: "I still have many inferiority complexes today. I felt foreign-which they also made me feel-it makes sense ... because they had remained in their Heimat ... but we were foreign. We felt as if we were intruders." We can see that it was not just the physical space that prevented feeling of being at home, but also the material hardships, lack of social networks, and myth of the eventual return to the homeland.

This phase of itinerancy was characterized by the dispersal of families, impermanent housing, accommodation in other people's homes, economic deprivation, and lack of privacy. Separation from families and friends, as well as
(C) Author(s), 2016. This open-access work is licensed under a Creative Commons Attribution-NonCommercial 4.0 International license.
Cette oeuvre en libre accès fait l'object d'une licence Creative Commons Attribution-NonCommercial 4.0 International. 
difficult relationships with hosts meant that they did not feel at home in the house they lived in. This period further entrenched the separation of the material house from the emotional home and led expellees to romanticize and idealize the image and memory of their home in the homeland, both still having the potential of being their permanent future home. "Home" then became constructed in terms of what "home" meant in the homeland and in opposition to what it represented in the early postwar period. The combination of a forced loss of the home and continuous hardships in West Germany entrenched this dream. Underlying it was a sense of ambivalence. Despite all the hardships, many were able to see that in the context of the war and the horrors of the Holocaust, they had been lucky. As Gardner argued, the "presence of emotions depends to a huge degree on the personal histories and characters of the individuals concerned," which can result in ambivalent feelings. ${ }^{2}$ How then did expellees integrate their two notions of home?

\section{The Third Phase: Settlement and Making a New "Home'}

The housing situation of expellees improved considerably in the 1950 as the result of the housing-building programs of the FRG (laws passed in 1950 and 1956), the 1952 Equalization of Burdens Law, foreign aid, and the "economic miracle." Furthermore, as Connor argues, the large proportion of expellees renting, buying, or building their own home reflected their "disinclination to be subtenants, resulting from the problems many had experienced when billeted with native householders in the early post-war years. Instead they preferred their own space and privacy." 53 In the early 1950 most of the new housing was intended as cheap rented accommodation; in the later 1950 s the emphasis shifted to building for ownership. Despite these improved housing conditions for expellees, the census of 1960 still recorded a gap between the housing situation of expellees and that of the native population, which was not closed until 1968.54

With the passage of time, many of the expellees became accustomed to their new surroundings, and the age and stage of their life course meant that many were starting families. Finally, the Cold War made a return to the homeland less likely and the "economic miracle" in Germany made staying more appealing. Eventually, many expellees recognized that they would have to accept their new location and started making their house into their home.

Eventually expellees became embedded in their new locality and problems faded into the background. As Helga explained, "It was only in the early period that they [the locals] sort of rejected the refugees a bit, but then it was ok." The embedding included increased economic security as expellees found permanent employment and pursued careers. Joining local clubs and associations was another important marker for establishing expellees' sense of belonging in their new home.

Most important though was the re-establishment of social relationships, in which local expellee organizations played a significant role. Political aims of reclaiming the homeland lost relevance during the Cold War, and social events brought expellees together, creating from their shared imagined identity, that was defined by loss and suffering, a real community, a network of support in the new environment. Everyday life also brought locals and expellees closer together, through work, as neighbours or children attending the same schools. Renate, for example, became close friends with a colleague of her husband and his wife, to the extent that they would go on holiday together. Erhard became close friends with his neighbours through their children. The next generation found it significantly easier and were often determined to integrate. Mixed marriages between locals and expellees, but also expellees from different areas of origin, were common. "Since the end of the 1960s and the early 1970 a break in the historical consciousness among the younger generation is observable." 55

The passage of time meant the creation of new families, as those who were children or young adults during the expulsion became adults and started a new stage in their life course. Especially the birth of children created a sense of belonging to the locality and a departure from a life defined by hardship. As Maria explains, "Soon our first daughter was born. She brought cheerfulness into our life. It was a gift from God."

With starting a new family came the desire for a physical and private space, which had now become a realistic possibility. Although this process was often long, in the majority of cases it led to expellees being able to own their own home, and, importantly, have privacy. Among the interviewees all but one were able to own their home. For Maria and her husband it was an especially long journey: "It took twelve years until we got our own house." In order to build housing, parishes had to find land as well as raw materials, which remained scarce. The result was often separate estates for expellees rather than individual houses integrated into towns and villages. Maria lives in such an estate to the north of Bremen. The result was clear territorial and spatial separations between locals and expellees. For Maria this was a positive experience: "After we built [our house] we were only among refugees, that was splendid!" To some extent it is here that the Heimat and the new home are combined, by creating a community of expellees only and recreating many aspects of the "life back home" such as subsistence farming. What binds this community together remains their common experience of loss and suffering, rather than their origin. In Maria's estate, for example, expellees came
(C) Author(s), 2016. This open-access work is licensed under a Creative Commons Attribution-NonCommercial 4.0 International license.
Cette oeuvre en libre accès fait l'object d'une licence Creative Commons Attribution-NonCommercial 4.0 International. 
from Bessarabia, Silesia, and Pomerania, as well as smaller numbers from other areas.

In her study of the Sudeten Germans in Bavaria, Svašek also found narratives of ownership and property compensating for their earlier losses. ${ }^{56}$ The house in its materiality, Mand further argues, acts "as a site for claims and counterclaims of belonging." ${ }^{2}$ Home and house thus become reintegrated.

Visits back to the homeland organized by expellee organisations also became common during this time and led to another important realization about expellees' previous homes: their memory of the Heimat no longer corresponded with its current reality. Their home in the Heimat no longer existed and could not be connected to the current geographic location. Although it was often painful for expellees to see new generations being born in "their" home, they also realized that this was not their home anymore. Instead, theirs was the home of their memory and now only existed in the past. George and Fitzgerald, Andrew Demshuk and Svašek found similar effects of such visits in their respective research: "The homeland was no longer home." 58

In this period many aspects of expellees' initial economic deprivation and markers of difference disappeared. Combined with the dwindling prospects of a return to their homelands, many expellees accepted the likelihood that they would remain in their "home by chance" permanently. This acceptance also altered the way expellees understood the physical space of home: once again the aim was to combine the house with the home, to establish in it feelings of security, familiarity, and privacy. This period represented a conscious effort by the expellees to fix their home into place. However, the memory of their Heimat and expulsion meant that they were not able to be completely and exclusively connect emotionally to their new home.

\section{Remembering and Narrating Home and Heimat}

I always say I am at home here, but my Heimat is Pomerania. It's been like this thus far, it will always be like this. That will never change. The way in which we left our Heimat was too painful for it to be any other way. It would be different if I had left voluntarily ... but if you are forced ... (Renate)

Well, here I am Zuhause [at home], because I have my children here, but I always say if I visit Silesia and I die there, then bury me there in the Lichter forest, don't bring me back ... Of course, my roots are there, that's just how it is. (Maria)

Renate and Maria illustrate how expellees have constructed home as a consequence of their experiences. They maintain connections to both their home prior to the
expulsion-Heimat-and their new home, locality, and house. Like transnational migrants, expellees integrate two homes. The main difference here is that one home is an imagined home of the past, preserved in memory. It is integrated into the second home, which is physical and current, creating a fluid relationship between the two. Each remains internally bounded and fixed in meaning and locality. Svašek ${ }^{59}$ and Cordell similarly found multiple constructions of home in their respective research, leading Cordell to argue that such an association represented "a certain schizophrenia" in feelings towards home. ${ }^{60}$

In a transnational context, Gardner also found multiple meanings of home being negotiated by her Bengali research participants, who integrated home as both "an idea and a set of social relationships and practices."61 Similarly expellees enmeshed their idea of Heimat with their social relationships and practices making up their new home.

Gardner argues that imaginings of home are "not stable; [they are] a product of personal and collective histories and change over time."62 Although that happens for expellees, their idea of the imagined Heimat eventually becomes fixed: Heimat remains in the past, and it is only the past home that is associated with Heimat, not its current geographical location. Expellees cannot physically return to their Heimat as it no longer exists. It is because of their displacement, loss, and feelings of homelessness over a long period of time that the image of Heimat becomes idealized, romanticized, and fixed. As Ahmed argues, it is the impossibility of return that combines places and memories and binds them together. ${ }^{63}$

Together with the notion of having "two homes," feelings of contradiction and ambivalence develop. As Gardner found, "migrancy and exile involve constant quarrel with where one comes from" and change over the life course. Ahmadi Lewin further makes the point that "for elderly immigrants, the meaning of home takes on a special character involving not only the fact that they have lost their homeland and former residence but also their history and home." 64 Renate referred to this loss of their history: "It is so important in life to have some foundations on which you can build ... and that was exactly what we had lost." For Maria this was also important. She elaborated on her research into her family's history and their home in Silesia that went back to the eighteenth century.

Additionally, Heimat remains important because the economic hardship experienced in the early postwar period still affects their feelings of acceptance fifty years later. ${ }^{65}$ In her study of Moroccan women's transnational lives, Salih also found that "the reason why [they] keep emotionally and economically investing in their country of origin [is] the social and economic marginalization they experience in the host country." 66
(C) Author(s), 2016. This open-access work is licensed under a Creative Commons Attribution-NonCommercial 4.0 International license.
Cette oeuvre en libre accès fait l'object d'une licence Creative Commons Attribution-NonCommercial 4.0 International. 
However, places are not just "constructs" in the imagination. They are also materially constituted locations. ${ }^{67}$ As Fog Olwig argued, home is not just an abstract space but a place of rooting, a set of practices, repetitions of social interactions, and the house itself. ${ }^{6}$ Gaining ownership of the material house or flat produced a process of rooting and belonging, in which the house became a home. Space becomes "reterritorialized" and the new territory becomes reinscribed with Heimat, shaped by the experiences of the expulsion, the loss, and the itinerancy of the early postwar period. The boundaries between the here (new home) and the there (Heimat) thus become blurred. The "there" that is the Heimat is no longer a real place, but an imagined place fixed in a past time and location and can exist only there However, Heimat can no longer be a real place because its inhabitants have been displaced, and Heimat now becomes part of the "here" in the imagination of the expellees, as well as in their everyday practices (engaging in subsistence farming, attending Heimat events) and in their social networks (a large majority of which are also expellees or refugees). The new home here and in the present is then always inscribed with the Heimat of the past there.

\section{Conclusion}

The aim of this article was to explore the meanings of "home" in relation to the experiences of German expellees following the Second World War. This mass displacement of people across Europe as the result of the war produced upheaval and disruption in the lives of millions. Although the expellees, refugees, and locals were all ethnic Germans, the experiences of loss and suffering, the housing arrangements of the early postwar period, and Germany's economic deprivation created strong attachments to Heimat among expellees.

Through narrative interviews with expellees this article identified three phases of change for the home: the loss of home, a period of itinerancy, and settlement. These phases significantly affected how expellees understand home. Despite the great separation between them and their Heimat through time and space, their feelings and memories about Heimat have remained strong. They were entrenched by the brutal loss, as well as the difficulties expellees experienced in their new destinations. Heimat has thus become the idealized and romanticized notion of the past and unchanged home. Eventually most expellees accepted that their homeland would not belong to Germany again. The longer they stayed in their new location, started families and careers, the more they belonged to their new communities.

The combination of the expellees' strong feelings for their Heimat and the eventual settlement in their new home made the meaning of home a concept full of contradictions and ambivalence. Home was not just a multidimensional concept, but to expellees it had two quite distinct fixed meanings, which stood in a constant influencing and fluid relationship to each other. Throughout all the narratives there was a very matter-of-fact approach towards this complexity and with it an acceptance that "this is just how it is."

The numbers of expellees are declining as they reaching the end of their lives, and their experiences will be lost if they are not captured. The difficulties they went through are just as much part of the German historical narrative as is the narrative of the "successful" integration of expellees and refugees and the war itself. The ability of expellees to look back on their experiences at the end of their lives from a secure and comfortable position can give us valuable insights into what forced displacement and reterritorializing a home can mean. Further exploration in the context of a globalizing world, increasing numbers of refugees worldwide, and Germany's place as a receiving country for increasing numbers of refugees today could help us develop an understanding of the challenges facing refugees in their host countries.

Vanessa Hughes is a PhD student at Goldsmiths, University of London. The author may be contacted atv.hughes@gold. ac.uk.

\section{Notes}

1 I. Connor, Refugees and Expellees in Post-war Germany (Manchester: Manchester University Press, 2007); A. Lehmann, Im Fremden ungewollt zuhaus. Flüchtlinge und Vertriebene in Westdeutschland 1945-1990 (Münich: C.H. Beck, 1991); P. Ther, "The Integration of Expellees in Germany and Poland after World War Two: A Historical Reassessment," Slavic Review 55, no. 4 (1996): 779-805.

2 L.H. Malkki, Purity and Exile: Violence, Memory and National Cosmology among Hutu Refugees in Tanzania (Chicago: University of Chicago Press, 1995), 2.

3 Lehmann, Im Fremden ungewollt zuhaus.

4 For example, see A. Demshuk, The Lost German East: Forced Migration and the Politics of Memory, 1945-1970 (New York: Cambridge University Press, 2012); and M. Svašek, "Narratives of 'Home' and 'Homeland': The Symbolic Construction and Appropriation of the Sudeten German Heimat," Identities: Global Studies in Culture and Power 9, no. 4 (2002): 495-518.

5 Lehmann, Im Fremden ungewollt zuhaus; R. Schulze, "The Struggle of Past and Present in Individual Identities: The Case of German Refugees and Expellees from the East," in Coming Home to Germany? The Integration of Ethnic Germans from Central and Eastern Europe in the Federal Republic, ed. D. Rock and S. Wolff, 38-55 (New
(C) Author(s), 2016. This open-access work is licensed under a Creative Commons Attribution-NonCommercial 4.0 International license.
Cette oeuvre en libre accès fait l'object d'une licence Creative Commons Attribution-NonCommercial 4.0 International. 
York: Berghahn, 2002); M. Svašek, "The Politics of Chosen Trauma: Expellee Memories, Emotions and Identities," in Mixed Emotions: Anthropological Studies of Feeling, ed. K. Milton and M. Svašek, 195-214 (Oxford: Berg, 2005); Svašek, "Narratives of 'Home' and 'Homeland': The Symbolic Construction and Appropriation of the Sudeten German Heimat," Identities: Global Studies in Culture and Power 9, no. 4 (2002): 495-518.

6 K. Cordell, "The Past, the Present, and Virtual Reality: A Comparative Assessment of the German Landsmannschaften," Journal of Baltic Studies 37, no. 1 (2006): 22-47; S. Wolff, "German Expellee Organizations between 'Homeland' and 'At Home': A Case Study of the Politics of Belonging," Refuge 20, no. 1 (2001): 52-64.

7 M. George and R.P. Fitzgerald, "Forty Years in Aotearoa New Zealand: White Identity, Home and Later Life in an Adopted Country," Ageing \& Society 32 (2012): 239-60.

8 A. Gupta and J. Ferguson, "Beyond 'Culture': Space, Identity, and the Politics of Difference," Cultural Anthropology 7, no. 1 (1992): 6-23.

9 See, for example, F.A. Lewin, "The Meaning of Home among Elderly Immigrants: Directions for Future Research and Theoretical Development," Housing Studies 16, no. 3 (2001): 353-70; Svašek, "Narratives of 'Home' and 'Homeland."'

10 K. Gardner, Age, Narrative and Migration: The Life Course and Life Histories of Bengali Elders in London (Berg: Oxford, 2002), 211.

11 S. Mallett, "Understanding Home: A Critical Review of the Literature," Sociological Review 52, no. 1 (2004): 62-89. 12 Ibid.

13 See, for example, Gardner, Age, Narrative and Migration; K. Fog Olwig, "A Wedding in the Family: Home Making in a Global Kin Network," Global Networks 2, no. 1 (2002): 205-18; Fog Olwig, Caribbean Journeys: An Ethnography of Migration and Home in Three Family Networks (Durham, NC: Duke University Press, 2007); R. Salih, Gender in Transnationalism: Home, Longing and Belonging among Moroccan Migrant Women (London: Routledge, 2003).

14 N. Rapport and A. Dawson, "The Topic and the Book," in Migrants of Identity: Perceptions of Home in a World of Movement, ed. N. Rapport and A. Dawson (Oxford: Berg, 1998), 4 .

15 Ibid., 9.

16 See, for example, S. Ahmed, "Home and Away: Narratives of Migration and Estrangement," International Journal of Cultural Studies 2, no. 3 (1999): 326-47; Gardner, Age, Narrative and Migration; Fog Olwig, "Wedding in the Family"; Fog Olwig, Caribbean Journeys; George and Fitzgerald, "Forty Years in Aotearoa New Zealand"; K. Mand, "I've Got Two Houses, One in Bangladesh, One in London, Everyone Has: Home, Locality and Belongings," Childhood 17, no. 2 (2010): 273-86; Salih, Gender in Transnationalism.

17 Fog Olwig, "Wedding in the Family," 216.
18 Mand, "I’ve Got Two Houses."

19 L.H. Malkki, "Refugees and Exile: From 'Refugee Studies' to the National Order of Things," Annual Review of Anthropology 24 (1995): 495-523.

20 B. Harrell-Bond and E. Voutira, "Anthropology and the Study of Refugees," Anthropology Today 8, no. 4 (1992): 7.

21 F. Stepputat, "Repatriation and the Politics of Space: The Case of the Mayan Diaspora and Return Movement," Journal of Refugee Studies 7, nos. 2/3 (1994): 175-85.

22 H. Fassmann and R. Munz, "European East-West Migration, 1945-1992," International Migration Review 28, no. 3 (1994): 521.

23 Connor, Refugees and Expellees; Ther, "Integration of Expellees in Germany and Poland."

24 See, for example, A.R. Seipp, "Refugee Town: Germans, Americans, and the Uprooted in Rural West Germany, 1945-52," Journal of Contemporary History 44, no. 4 (2009): 675-95.

25 Connor, Refugees and Expellees, 174.

26 A. Thomson, "Moving Stories: Oral History and Migration Studies," Oral History 27, no. 1 (1999): 24-37.

27 Lewin, "Meaning of Home among Elderly Immigrants."

28 A.M. Findlay and F.L.N. Li, "An Auto-biographical Approach to Understanding Migration: The Case of Hong Kong Emigrants," Area 29, no. 1 (1997): 34-44; A. Thomson, "Moving Stories: Oral History and Migration Studies," Oral History 27, no. 1 (1999): 24-37; M. Chamberlain and P. Thompson, eds., Narrative \& Genre: Contexts and Types of Communication (New Brunswick, NJ: Transaction Publishers, 1998).

29 L. Abu-Lughod, Writing Women's Worlds: Bedouin Stories, (Berkeley: University of California Press, 1993), ACLS Humanities e-book.

30 Gardner, Age, Narrative and Migration, 31.

31 C.B. Brettell, Anthropology and Migration: Essays on Transnationalism, Ethnicity, and Identity (Walnut Creek, CA: Altamira, 2003), 25, 32, 44.

32 Wolff, "German Expellee Organizations," 53.

33 Connor, Refugees and Expellees, 165.

34 Malkki, "Refugees and Exile," 498.

35 For example, the 1952 Lastenausgleichsgesetz (War Burden Redistribution Act) and the 1953 Bundesvetribenengesetz (Federal Expellee and Refugee Law). Wolff, "German Expellee Organizations," 55.

36 Malkki, "Refugees and Exile," 497-8.

37 Lehmann, Im Fremden ungewollt zuhaus, 20.

38 Ther, "Integration of Expellees," 781.

39 Svašek, "Narratives of 'Home' and 'Homeland"; Wolff, "German Expellee Organizations."

40 Connor, Refugees and Expellees.

41 Ibid.

42 Ibid., 30-1.

43 Ibid., 32.

44 Ibid., 139-40.
(C) Author(s), 2016. This open-access work is licensed under a Creative Commons Attribution-NonCommercial 4.0 International license.
Cette oeuvre en libre accès fait l'object d'une licence Creative Commons Attribution-NonCommercial 4.0 International. 
45 See, for example, Gardner, Age, Narrative and Migration; George and Fitzgerald, "Forty Years in Aotearoa New Zealand."

46 Svašek, "Narratives of 'Home' and 'Homeland."

47 Cordell, "Past, the Present, and Virtual Reality."

48 N. Lovell, "Introduction," in Locality and Belonging, ed. N. Lovell (London: Routledge, 1998), 12.

49 Connor, Refugees and Expellees, 69.

50 Ibid., 64.

51 Schulze, "Struggle of Past and Present," 44.

52 Gardner, Age, Narrative and Migration, 18.

53 Connor, Refugees and Expellees, 140.

54 Ibid.

55 Lehmann, Im Fremden ungewollt zuhaus, 83.

56 Svašek, "Narratives of 'Home' and 'Homeland."'

57 Mand, "I've Got Two Houses," 276.

58 George and Fitzgerald, "Forty Years in Aotearoa New Zealand," 251; and Svašek, "Narratives of 'Home' and 'Homeland."'
59 Svašek, "Narratives of 'Home' and 'Homeland," 498.

60 Cordell, "Past, the Present, and Virtual Reality," 41.

61 Gardner, Age, Narrative and Migration, 4.

62 Ibid., 23.

63 Ahmed, "Home and Away," 343.

64 Lewin, "Meaning of Home among Elderly Immigrants," 366.

65 Schulze, "Struggle of Past and Present," 44.

66 Salih, Gender in Transnationalism, 53.

67 Gardner, Age, Narrative and Migration, 218.

68 K. Fog Olwig, "Epilogue: Contested Homes: Home-making and the Making of Anthropology," in Migrants of Identity: Perceptions of Home in a World of Movement, ed. Nigel Rapport and Andrew Dawson, 225-36 (Oxford: Berg, 1998). 


\title{
Between Law and the Nation State: Novel Representations of the Refugee
}

\author{
SIMON BEHRMAN
}

\section{Abstract}

Given the degraded profile of the refugee in contemporary discourse, it is tempting to seek alternatives from a rich tradition of literary tropes of exile. However, this article argues that the romanticized figure of the literary exile ends up denying, albeit in positive terms, a genuine refugee voice, as much as the current impersonal hegemonic concept of the refugee as found in law. Ultimately, the spell in which refugees find themselves trapped today can be broken only by opening up a space of politics in which the refugee herself can be heard.

\section{Résumé}

Étant donné le profil dégradé des réfugiés(e)s qui existe au sein du discours contemporain, la tentation de trouver d'autres possibilités d'approche à partir d'une riche tradition de figures littéraires de l'exil s'impose. Cet article maintient, cependant, que la figure romantique littéraire de l'exil aboutit, bien qu'en termes positifs, à un reniement de la voix authentique des réfugié(e)s, au même titre que la conception hégémonique et impersonnelle des réfugié(e) $s$ que l'on trouve actuellement dans la législation. En fin de compte, le sort qui tient les réfugié(e)s prisonniers ne peut être brisé que par la création d'un espace dans la dimension politique qui puisse donner voix aux réfugié(e) seux-mêmes.

\section{Introduction}

7 he figure of the exile in literature, or the literary figure in exile is a familiar, if not in fact a hackneyed one. However, over the last fifty or so years, this tradition has died out. In its place we find, instead, the exile not so much as hero as victim; shamed rather than valorized; an object of history as opposed to being an active shaper of her own life and of the broader sweep of events. The refugee is no longer a romantic figure, overcoming tragedy to triumph. In this article I identify two major reasons for the break between the exile literatures of the past and those of the present. The first is the post-colonial settlement, which has left us with a fairly rigid international state structure, demarcated with borders that are becoming ever-more policed and impassable. Previously migrants of all types had benefited from much more contingent spaces, that is to say spaces in which sovereignty was contested, often overlapping or in flux, and where there were little to no border controls. Second, the advent of the international refugee law regime has transformed the asylum-seeking process from one dominated by rival political or religious ideologies, in which refugees were often active subjects, to a highly bureaucratized process focused on categorizing and managing the movement of migrants.

In this depoliticized and delegitimized nadir of the refugee, perhaps one place to seek out her voice is in literature. There is now a rich stream of writing on the relationship between law and literature, which variously seeks out law as described in literature, law as itself a literary form, and other parallels. ${ }^{2}$ It is sometimes claimed that whereas law presents itself as Truth, literature offers itself as an artful reflection of reality. Therefore, there is a space within literature in which the monolithic narrative of law can be ruptured. ${ }^{3}$ But equally, the relationship can flow in the opposite direction, whereby hegemonic legal concepts become reflected in literature and beyond into the wider culture. In short, as Kieran Dolin notes, works of literature "may question the boundaries established by the law, or they may simply reflect such boundaries."4 So in this article, while attempting to show 
how images of refugees are passed into literature from the law, I am also interested to see whether or not literature, in turn, creates what Edward Said has described as an "affiliative" space, within which the refugee can be reimagined. In The World, the Text and the Critic, Said describes "filiation" as the adherence to a tradition-including "a party, an institution, a culture, a set of beliefs, or even a world-vision."5 "Affiliation," on the other hand, is also an order, but one to which one consciously adheres. Filiation is an example of a "natural" or established order-filial, the father, etc. Thus the "filiative scheme properly belongs to the realms of nature and of 'life,' whereas affiliation belongs exclusively to culture and society." 6 The real problem arises when social orders are presented as filiative, and thus natural and fixed, law and the nation-state being prime examples, seen as inescapable facts of a well-ordered, civilized life. It is therefore the job of critical pursuits, whether academic, literary, or political, to intervene and disrupt in ways that are "affiliative." Thus, in relation to the refugee, I am seeking here to interrogate the extent to which the pseudo-filiative subjects of law and the nation-state are reinforced or challenged within the supposed affiliative space of literature. I do this through a reading of three novels-Exodus by Leon Uris (1959), Shame by Salman Rushdie (1984), and Refugee Boy by Benjamin Zephaniah (2001) - that cover the period of transition from the refugee as hero to that of victim or threat.

From Hannah Arendt through to contemporary writers such as Liisa Malkki and Philip Marfleet, the role of the nation-state in the creation of the modern refugee subject has been clearly laid out.7 The "imagined community" of the nation, founded upon notions of belonging based on a shared culture, language, and space necessarily also produce the subject of an alien other against whom the nation defines itself. ${ }^{8}$ The twentieth century is littered with bloody examples of this phenomenon-the great "unmixing of peoples" following the collapse of the Ottoman and AustroHungarian Empires, the partition of India and Pakistan, the creation of the state of Israel, the collapse of Yugoslavia. What is interesting, however, is that in each of these cases, along with many others, the refugee subject had a dual aspect. For as well as being the alien other of one state, that negative image had a positive one as the human material of a new state. As Arendt saw, those refugees who had no connection with any state whatsoever faced the ultimate degradation. In the 1930 s this was the fate of the European Jews, now it is the reality of the Palestinian diaspora. One interesting aspect of Exodus is the valorization of the former through their striving towards statehood. However, today the post-colonial settlement has, for the most part, closed off the route to valorization via the creation of new states. 9 The experience of most refugees today therefore is that of a "waste" product either warehoused in the archipelago of camps and detention centres or shunted around borders and seas in search of asylum. ${ }^{10}$

Another fundamental difference between refugee literature then and now is that up until very recently the legal process played, at most, a marginal role in their narratives. This can be easily explained. Until the twentieth century the legal category of the refugee did not exist. ${ }^{11}$ One of the first encounters between the refugee and law that we can find in literature is W.H. Auden's Refugee Blues. Written in 1939, this poem reflects the experiences of refugees in the age of passports, border controls, and the first abortive attempts at defining and ordering the refugee in international law. ${ }^{12}$ Describing the experience of a Jewish couple arriving somewhere from Nazi Germany, the fourth stanza reads:

The consul banged the table and said,

"If you've got no passport you're officially dead":

But we are still alive, my dear, but we are still alive. ${ }^{13}$

The equation of death with lack of citizenship-civic death-is, with the exception of that other law-bound epoch, ancient Rome, a peculiarly modern concept. Only fifty years before Refugee Blues, refugees were able to move across Europe and gain asylum with few restrictions. ${ }^{14}$ Today, of course, the experience of reaching a potential country of asylum lacking a passport, visa, or other bona fide document is a common one. So too the refusal of asylum for this lack is also all too common an event today.

Just a few years after Auden's poem we find a similar concern with legal documentation as a necessary pathway to asylum in the classic film Casablanca (1942). ${ }^{15}$ Daniel Steinbock makes an excellent case for the film as revealing the ideological framework that would, within a decade, determine the shape of international refugee law. ${ }^{16}$ Casablanca preaches the morality of assisting the refugee to find asylum. Yet, as Steinbock demonstrates, there are two important qualifications. First, it is up to a decision-maker (represented in the film by Rick Blaine) to weigh up just who deserves asylum. Second, the image of the deserving refugee is one of almost unbelievable worthiness. Victor Laszlo is a political refugee from a criminal regime, whose character demonstrates almost no flaws. Instead he is repeatedly shown to be a man of the highest moral probity, unfailingly polite, speaking impeccable English, and always well dressed. This is all a far cry from the reality of most refugees from the Nazis, who were often of far less means and forced to skate difficult lines of moral judgment in order to survive. This is not to denigrate these or indeed any other refugees. The point is that no one is able to achieve the kind of uncomplicated goodness of a Victor Laszlo. It is telling
(C) Author(s), 2016. This open-access work is licensed under a Creative Commons Attribution-NonCommercial 4.0 International license.
Cette oeuvre en libre accès fait l'object d'une licence Creative Commons Attribution-NonCommercial 4.0 International. 
that such a fictional construct is necessary in order to earn our sympathy. In the age of refugee law, of judgment on who is or is not a genuine and deserving refugee, we must believe that the claimant's credentials are of the highest standard. This type of characterization can be seen as closely linked to an equally flat and romantic construction of the refugee within refugee law. The legal category of refugee rests upon certain criteria, which perhaps have more to do with what we consider to be an ideal-type rather than reflecting the myriad reasons for forced migration. The 1951 UN Refugee Convention, which is the foundation of international refugee law, insists that a genuine refugee must have left the borders of her country of origin, and that her persecution is for very particular reasons to do with religious or political belief, or due to her race, nationality, or social group. ${ }^{17}$ In other words, only those who have demonstrated will, the ability to travel, and usually some traits of courage and/or tragedy can be "genuine" refugees. So in Casablanca, and as we shall see, in Exodus, Shame, and Refugee Boy too, the affiliative space opened up leads in fact to a reaffirmation of the filiative categories of law.

What should become apparent as we journey with the refugees at the heart of these three novels is that we have moved from one idealized trope of the refugee to another, neither of which captures the complexities of the refugee experience. The voices we hear in these narratives tend to ventriloquize for forces beyond themselves - the nation, the law-whereas the earlier literature of exile tended to focus on the voice of a single individual resisting the tides of fate. At the same time, the narrative structure of the novel does at least allow us a window onto the experiences of the contemporary refugee that is all too often obscured by the statistics and headlines that dominate the discourse on migration today.

\section{Exodus: A (Nation) State of Being}

The Refugee as Hero ...

Leon Uris's novel Exodus tells the story of the creation of the state of Israel from the arrival of the first Jewish refugees from Europe in the latter half of the nineteenth century through to the establishment of the state in $1948 .{ }^{18}$ Many of the protagonists are clearly presented as archetypes of the phenomenon of the Jewish flight from Europe, fleeing the pogroms and later the Nazis. The tale of the two brothers Jossi and Yakov who are forced to flee their home in Russia for Palestine in the 188 os stands in for the many thousands more who left the Pale of Settlement in the closing decades of the nineteenth century. ${ }^{19}$ The tale of their three-and-ahalf-year trek to Palestine is described in the most heroic terms, as they trudge through snow, "bending their young bodies against howling winds." ${ }^{20}$ By the time they reach the
Promised Land they have achieved almost superhuman proportions: "Jossi had grown into a lean and leathery giant six feet three inches tall with a frame of steel." ${ }^{21}$ Karen Clement's experiences mirror those of Jews forced to flee after the Nazi takeover in 1933, and their subsequent march through Europe. And finally, Dov Landau's story follows those who, after suffering the degradations of the death camps, were then spat out into the displaced persons (DP) camps at the end of the war. These successive waves of refugees are referred to in Zionist historiography as the aliyahs. The first aliyah is often called the farmers' aliyah, including those such as Jossi and Yakov who arrived in the last decades of the nineteenth century. "[The] Second Aliyah [1904-14] brought ideals and leaders and the Third Aliyah [1919-23] brought the pioneers - the German Aliyah [post-1933] resulted in a tremendous cultural and scientific spurt in the Yishuv."22 Thus each successive wave of refugees is celebrated not for who they are, but rather for what they will contribute to the founding of the nation. Heroic as they are, their identities are collapsed into the "national order of things." 23

Before we see the refugees themselves, we are introduced to them through the eyes of the British military officers in charge of a DP camp in Cyprus, where they are being held virtually prisoner in terrible conditions. The anti-Semitic officer Major Caldwell refers to them as "unruly" and in need of "some good old-fashioned discipline."24 But Brigadier Sutherland cautions that not only are the DPs not criminals but that "they've got world sympathy on their side." 25 Later, when a boatload of refugees are on hunger strike demanding that the British authorities allow them into Palestine, a general orders that the whole affair must be handled with "great tact," for "no one wants to ride herd on a bunch of downtrodden refugees ... they have a great deal of sympathy on their side in high quarters ... We want nothing to happen to create an unfavourable opinion." ${ }^{26}$ Thus we have a clear picture of the refugee as one who commands sympathy and respect from wider society, if not from the authorities. This solidarity, or at the very least empathy, is, therefore, what gives the refugees real protection and a certain guarantee of sanctuary, irrespective of their legal status. A political judgment on the refugee question, rather than a purely legal one, was still in play at this time, and worked to the refugees' advantage.

A second important and rare aspect of Exodus that follows is the celebration of "illegal immigration" as a heroic act. Indeed the mass of refugees is conceived of as part of the Zionist army of liberation. "Illegal immigration ... that is the way we will fight them," says Avidan, the commander of the Hagganah. ${ }^{27}$ This is an accurate reflection of the Zionist project, which championed such immigration as a weapon against the Arab majority then living in Palestine, as well
(C) Author(s), 2016. This open-access work is licensed under a Creative Commons Attribution-NonCommercial 4.0 International license.
Cette oeuvre en libre accès fait l'object d'une licence Creative Commons Attribution-NonCommercial 4.0 International. 
as the British Mandate authorities. And it is this aspect that is crucial to the sympathetic portrayal of refugees in the novel, for the Jewish refugees are not fleeing their homelands but are returning to it. That is, according to Zionist ideology, they are returning to a land that is rightfully theirs, in order to build their nation. When Zionist agents break into a DP camp in Cyprus, they "set up schools, hospitals and synagogues, [build] sanitation facilities, and [organize] light industry." 28 It is the impact of a political ideal framed in terms of an identity rooted in nation that raises the refugees to the level of a "civilized" community. Further, the camps are turned from ones of internment into centres for the eventual struggle in Palestine, with the Zionist agents training the refugees in military tactics, "Arab psychology," and Palestinian geography. ${ }^{29}$ At the end of the novel the emigration of the Yemeni Jews to the newly created Israeli state is framed in similar terms. Initially they are "tragic figures ... dressed in rags, filthy and half dead"; they are "semi-primitive people." 30 But on arrival in Israel they are cleaned up and introduced to civilization in the form of "motor vehicles, medicine, western dress." In short, they really become human only with their subsuming into the modern nation-state. The final transformation of the refugee Jossi into the heroic figure of the novel is his adoption of a Hebrew name-Barak Ben Canaan-and his insistence on speaking Hebrew instead of Yiddish. When his wife resists this, he responds, "Yiddish is the language of exiles. Yiddish is the language of the ghetto. Hebrew is the language of the Jews." ${ }^{1}$ Thus, in multiple ways the illegal immigrants are ultimately valorized only through their role as creators of the nation-state.

\section{... to the Refugee as Threat}

The contrast with the portrayal of the Arab refugees during the war of 1948 is stark. They are described in impersonal and faintly bestial terms. There are no individual characters drawn for us to give them life and a multi-dimensional image. Instead they are described as a mass "stampeding" in their flight from their homes. In Acre the Arab refugees resist in only a "half-hearted" and "feeble" manner. This weakness then spreads like an "infection" to other Arab centres. ${ }^{32}$ Repeatedly throughout the novel the Arabs are set up as a foil for the nobility of the Jewish refugees. This is done either by presenting the Jewish refugees as tragic victims, or as heroic nation-builders and cultivators of the land. Brigadier Sutherland describes seeing the Arab slave markets and hand amputations, and then contrasts them with witnessing the plight of the Jews in Belsen.33 When Jossi and Yakov arrive in Palestine, they find that the land has fallen victim to "a thousand years of Arab and Turkish neglect."34 It will be the task of these refugees to "make the desert bloom." Here the "host" community is othered, while it is the refugees who are valorized as bringing economic development and civilization. Amongst other things, what the Palestinians lack and what the Zionist project brings is the nation-state.

The climax of the novel is the achievement of statehood by the Zionists. And with this development comes a shift in how the figure of the refugee is presented. After spending some 600 pages lionizing refugees as heroes and harbingers of progress, a problem arises as to how to deal with the obvious issue of the hundreds of thousands of Arabs forced from their homes during the violent establishment of the state of Israel. Uris adopts a number of literary and political frameworks to mark out the distinction between the sets of refugees. First, the Arab exodus is dealt with not in narrative, not by describing the experiences of the refugees themselves. Instead, it is presented in the form of an Israeli government report prepared by Ben Canaan. This has the effect of creating distance between the reader and the refugees. Second, all the metaphors of backwardness are thrown at the Arabs-they are dupes played on by their leaders for their "illiteracy, superstition, and fanatical devotion." 35 Third, their flight is branded as being a result of "blind fear and ignorance" rather than of any genuine fear of persecution. Ergo, in the language of the law, as set out in the 1951 convention, their fear of persecution is not wellfounded. Fourth, their flight is described as being merely a political act aimed at embarrassing the Zionists. Here we have a sharp reversal following the repeated emphasis on Jewish refugees to Palestine being a politically heroic act. The difference is that the Jewish refugees are described as active subjects, whereas the Arabs are presented as objects in the hands of their malevolent leaders-"caged like animals in suffering as a deliberate political weapon." Finally, the return of the Arab refugees is ruled out on the grounds that they would be a "hostile minority, pledged to destroy the State."36

Throughout Ben Canaan's report there are remarkably few verbs deployed to describe the Arab refugees themselves. Instead, will resides almost exclusively with the opportunist Arab leaders, with the refugees as their objects. By contrast the contemporaneous Jewish refugees from across the Middle East are endowed with their own volition. The refrain of "they came from ..." is alternated with phrases such as "walked through burning deserts," "arose from the melahs," "fought their way to ...," etc.37 The tropes of backwardness and lack of justification for flight are familiar to those used to the contemporary discourse on refugees. But for me the most striking element in this passage of the novel, which is itself an accurate reflection of Zionist historiography on the subject, is the stripping away of the political subjectivity of 
the Arab refugees, as distinct from their role as objects of political strategy. Moreover, there is the arrival of the state as a supreme subject whose rights outweigh those of the refugees. The sanctity of the nation-state, even a nascent one, is asserted against the threat of the refugee mass. In short, Uris has used literary forms to frame the transformation of the affiliative project of Zionism into the filiative state. So here literature has been used to both open up and then close the affiliative space. The voices of refugees engaged in making and shaping the world around them have been silenced in the face of the unimpeachable priority of state preservation. In Exodus, as in the actual historical events it describes, this phenomenon is presented in concentrated form. Key to this process is the encrustation of political and ethical notions of justice-e.g., the need for Jews to find safety from persecution in Europe, the right of Arab Palestinians to return to their homes, etc.- -with a colder, more impersonal juristic view on their plight. The fact that the problem of the Arab refugees is dealt with by Uris using the literary form of a government report, and an emphasis on the threat to state security by their return, is emblematic of this legalistic turn. The reasons can be glimpsed at the very beginning of Ben Canaan's report, when he describes the Arab refugee problem as "the most potent political weapon in the Arab arsenal"; ${ }^{38}$ echoes here of the British Mandate authorities' concern that the Jewish refugee arrivals in Palestine had "world opinion on their side." So long as the cause of refugee protection is seen as just in itself, states find themselves forced to admit them. A recent example of such a phenomenon was the widespread sympathy for refugees crossing the Mediterranean, sparked by the shocking images of their plight hitting news bulletins and front pages, which pushed a number of EU states to temporarily suspend the normal legal restrictions imposed on their movements. The task for the state in such situations, therefore, is to delegitimize the cause of the refugees. One of the most powerful methods of doing this is to reframe claims for asylum in legal rather than purely political terms. Failure to meet the legal standard leads ipso facto to the illegitimacy of the claim and the perception that the problem lies with those seeking to abuse the system of refugee law, rather than those enforcing it. The judgment of the law is final, whereas in the political sphere, claims can be infinitely contestable. The extent of the factual inaccuracies and political prejudices that can be found throughout Exodus call into question its value as a historical novel. ${ }^{39}$ However, what it does offer us is a window on a historical turning point in which the refugee hero of putative nation-states became the sinister and pathetic mass who threaten the nation-state order. The temporal frame of this change in Exodus covers almost seventy years, and indeed during this period the shift was incremental. Moreover, the novel closes in the late 1940s, on the cusp of the great process of decolonization that swept the globe, and just before the laying down of the first comprehensive international legal regime regulating the movements of refugees. In the next two novels, we witness the effects and after-effects of these later events.

\section{Shame: The Refugee Stripped and Revealed}

The titular theme of Salman Rushdie's novel Shame begins with the shame of refugeehood. 40 The violence that accompanies the partition of India and Pakistan launches the infamous mass exodus in both directions across the newly created frontier. For Bilquis Kemal (soon to be the wife of Raza Hyder, loosely based on the real-life General Zia UlHaq), Partition sees her fleeing from her home when a sectarian bomb blows apart her father's cinema, and their house that lies behind it. The shawl that covers Bilquis's naked body is burnt to mere threads by the force of the blast, and her eyebrows are permanently singed off her face. It is only as she has fled along with many others that she becomes aware of her nudity, and cries with shame. No one listens or responds, as they are all in panicked flight too. The stripping of Bilquis's modesty is offered by Rushdie as a metaphor for the exposure of refugees to the vicissitudes of their fate: "All migrants leave their pasts behind, although some try to pack it into bundles and boxes-but on the journey something seeps out of the treasured mementoes and old photographs, until even their owners fail to recognise them, because it is the fate of migrants to be stripped of history, to stand naked amidst the scorn of strangers upon whom they see the rich clothing, the brocades of continuity and the eyebrows of belonging." 41

The shame of Bilquis's physical nakedness thus stands for the shame of the refugee stripped of all attributes of modern civilization-rootedness, community, and belonging. Here we may pause to consider Giorgio Agamben's use of the term la nuda vita (bare life) to describe the modern refugee along with all those others who have been stripped of the accoutrements of a civilized life, indeed of any life beyond mere existence. ${ }^{42}$ Bareness and nudity in Italiannuda-(and the French nue) are one and the same term. The nudity of Bilquis is certainly a source of shame, and that is how Rushdie adopts it as his metaphor. But bareness can also be positive- "the naked truth," or as it is expressed in Italian, la verità nuda e cruda. The Oxford English Dictionary gives various definitions for bare such as "Stripped of surroundings, contents, property. Defenceless, unprotected, deserted"; "Laid waste, desolate"; "Without possessions, destitute, indigent, needy"; "Poor in quality, paltry, worthless." But it can also mean "To make or lay bare, uncover, open to view”; "To disclose, reveal, make manifest." In Agamben's
(C) Author(s), 2016. This open-access work is licensed under a Creative Commons Attribution-NonCommercial 4.0 International license.
Cette oeuvre en libre accès fait l'object d'une licence Creative Commons Attribution-NonCommercial 4.0 International. 
work, we can certainly see both senses of the term at work: life stripped of any meaning beyond existence, but also a life that although seemingly at the margins reveals, uncovers something fundamental to the hegemonic form of life created by juridically constituted sovereign power. Agamben's thesis echoes Rushdie's evocation of the rootlessness of urban life when he describes the city as "a camp for refugees." 43 Thus Bilquis's nudity is not just her shame, but also a striking exposure or revelation of the refugee experience in the twentieth century. Her shame along with that of the millions of her fellow refugees, and the subsequent attempts to overcome it through the construction of a nation-state founded upon war and military glorification, will lead to a denouement where refugeehood is revisited, only this time as abject tragedy. Once again, just as with Exodus, attachment to a romanticized figure of the refugee as nationbuilder will end with the transformation of the refugee subject into its flip side: pathetic victim.

For Bilquis, flight and her shame lead her to apparent happiness when she meets her future husband Raza in the makeshift refugee encampment. Here they marry "beneath the bitter eyes of the dispossessed multitudes." Already Bilquis is trying to absolve her shame by rising above the embarrassing mass of fellow refugees around her. Their wedding is carried out, "isolated behind [a] screen from the dull, debilitated anger of the mob ... 'Tch tch,' she reproached the glowering refugees, 'but this envy is too terrible thing." 44 The newlyweds move on to Pakistan-the "bright new world" of the new nation-state, of an end to statelessness and bare life. Indeed, Raza is able to offset some of the shame of being a refugee when his first successful military exploits in the war following Partition demonstrate "the advantages of the energy-giving influx of immigrants." 45 Here affiliation is key, the refugee an active subject of history. The shame of rootlessness is expiated by the founding of a new polis within which the refugees can rebuild their identities. They are able to do this through being the architects of their own subjectivity. But, and this is the crucial point, their revival as valorized subjects is inextricably linked to the nationstate, as was the case for the Jewish refugees in Exodus.

In response to the insult of "Mohajir! Immigrant!" thrown at Bilquis, Rushdie as narrator steps forward in an extended passage to ruminate on the migrant experience:

I, too, know something of this immigrant business. I am an emigrant from one country (India) and a newcomer in two (England, where I live, and Pakistan, to which my family moved against my will) ... The anti-myths of gravity and of belonging bear the same name: flight ... To fly and to flee: both are ways of seeking freedom ... When individuals come unstuck from their native land, they are called migrants. When nations do the same thing (Bangladesh), the act is called secession. What is the best thing about migrant peoples and seceded nations? I think it is their hopefulness. Look into the eyes of such folk in old photographs. Hope blazes undimmed through the fading sepia tints. And what's the worst thing? It is the emptiness of one's luggage. I'm speaking of invisible suitcases, not the physical, perhaps cardboard, variety containing a few meaning-drained mementoes: we have come unstuck from the land. We have floated upwards from history, from memory, from Time. ${ }^{46}$

Here Rushdie expresses the dual nature of exilic movement as both positive and negative, dreaming of flight, freedom, but also the emptiness, the draining away of identity. Partially this duality has to do with the blurring of the distinction between forced and voluntary migration. For those forced to flee, their hope is often limited to an end to the persecution or other dangers that they have led to their flight. But as Liisa Malkki, adopting the same metaphor as Rushdie, has written, "People who are refugees can also find themselves quite quickly rising to a floating world either beyond or above politics, and beyond or above history-a world in which they are simply 'victims."'47 This is recognized at the climax of Shame, when Bilquis and Raza are once more forced to flee, only this time not to forge a new nation-state, but rather as is the case with most refugees in modern times, simply to seek safety. Here the description of their flight is raw, of little to eat, drinking water from dirty lakes, the constant fear of capture before crossing the frontier, and finally their vulnerability in their apparent sanctuary leading to a shameful death bathed in their own filth: "There is no country poorer than Escape."48 Thus the duality of exile that Rushdie describes reflects both an older romantic exile familiar from literature - the Dantes and the Robinson Crusoes-for whom forced migration represents a journey of discovery, a figurative view from above, and also the banal realities faced by most forced migrants.

One arc of the novel is that from the heroic refugee who rises above the shame of the bareness of refugeehood through the construction of a new national identity to the refugee of today, deprived of any opportunity to reassert her active subjectivity, who must instead rely on the passive and precarious reliance on survival and help from others. What links the two ends of this trajectory is a two-dimensional subjectivity imposed upon complex characters. The romanticized refugee subject whose flight becomes the basis of the founding of the nation-state is but a cypher for that political project. Once the project is completed, the rootlessness of the refugee becomes instead an embarrassment, an affront to the pride of the nation. And so, again, once the affiliative space has closed, replaced by the bordered space of the state, the refugee finds herself excluded and despised. A similar
(C) Author(s), 2016. This open-access work is licensed under a Creative Commons Attribution-NonCommercial 4.0 International license.
Cette oeuvre en libre accès fait l'object d'une licence Creative Commons Attribution-NonCommercial 4.0 International. 
trope is at work at the end of Exodus, with the depictions of the post-independence Arab Jews. Whereas once the refugee reflected the aspirations for a nation-state, in the post-colonial context she has, as Arendt and Agamben have identified, become a symbol of those who lack that ultimate modern signifier of civilization: citizenship. However, it should be noted that with Rushdie, the opening and closing of the affiliative space is presented as what it is: a reversal in the fortunes of the refugee. Rushdie thus uses literature as a means to trouble and destabilize established notions of the refugee subject, whereas in Exodus the literary forms deployed are used to reinforce them.

\section{Refugee Boy: Dehumanized by Law, Re-Humanized by Politics}

Refugee Boy by Benjamin Zephaniah, published in 2001, represents a decisive change in refugee literature. 49 The flux of decolonization, which allowed for at least some space for the heroic refugee in Exodus and Shame, has been replaced by the hegemony of the "new world order." In Refugee Boy, in addition to the post-colonial context, a second and highly virulent phenomenon is also visible in the refugee experience: the legal process of seeking asylum. Half a century after the 1951 Refugee Convention, and in the immediate wake of a succession of pieces of asylum legislation in the United Kingdom, the refugee as shaped by and shaper of great historical events has given way to the mundanities of life in poverty, reliance on the host state for subsistence, and the legal process of refugee status determination. This effect is partly a result of Zephaniah's hyperrealist style. But by the same token this realism accurately reflects a historical phase in which the refugee subject, as expressed through political discourse and legal structures, has indeed been stripped of her heroism and place in the making of history. Therefore, in this novel the struggle of the refugee has been shifted from the realm of world historical events to the much narrower space of law. The examples that we have looked at so far-the creation of the states of Israel, India, and Pakistan-have all passed into our collective consciousness as epoch-making events. Moreover, the refugees in all these situations were bearers of hope for progressive change. In Refugee Boy, however, the refugee in question, a teenaged boy fleeing the war between Ethiopia and Eritrea, is a product of a conflict existing at the periphery of contemporary globalized consciousness. Indeed, insofar as most people in the West register this region in their consciousness, it is in the images of abject suffering and victimhood that were popularized by the Band-Aid phenomenon of the mid-1980s: "Do they know it's Christmas time?"-a question that could be asked only about people seen as far beyond the borders of civilization. Of course, this problem of marginality is due partly to the endemic racism that persists, even in our post-colonial epoch. Yet we do not have the same sense of distance from the refugee-producing events in Uris's Exodus and Rushdie's Shame, which also deal with situations arising in the Global South. The question of Palestine was dominated by the machinations of European powers, and the partition of India and Pakistan was related directly to the fall of the British Raj, and thus these events were intimately and obviously connected to the politics at the centre of global power. For sub-Saharan Africa today, systematically raped by Western corporations for its natural resources, but politically long-since independent from the polities of the West, the wars of the continent are in the collective consciousness there merely quarrels "in a faraway country between people of whom we know nothing." 50 Yet, as we shall see, while Refugee Boy represents in key respects a further qualitative move away from the refugee literature of the past, it still ends up cleaving closely to a romanticized refugee subject capable of being valorized within the dominant discourse.

A central feature of the refugee experience today around which the narrative of Refugee Boy pivots, one that was either unknown or peripheral to refugees previously, is the grinding process of refugee status determination. The post-colonial absence of a grand political project of nationbuilding leaves refugees from the Global South almost wholly dependent on legal definitions as justification for asylum. The juridical process has the effect of creating subjects stripped bare to the essentials of the legal definition, and to the resulting passivity and dependence upon the host country. Legal categorizations, such as that of refugee, can be the ultimate in filiative spaces. In other words, questions of belonging and acceptance that were once the subject of contestation become objectified and fixed. Zephaniah's novel powerfully evokes the feelings of alienation, confusion, and lack of control experienced by the refugee as he is forced through the legal system. This begins when Alem, the eponymous refugee boy, makes his initial claim for asylum. After he is "photographed, fingerprinted, interviewed and given a number," Alem's hearing takes place in a "menacing building" that is "grey and lacking in colour."51 Again, this is both an accurate description of a court building and figuratively a description of the cold impersonality of the law. This is then momentarily disrupted by an expression of humanity in the hearing by Alem himself. After the judge announces an adjournment and makes the perfunctory inquiry as to whether the applicant has anything to say, Alem shocks the judge and his own counsel when he wishes everyone in the court "Happy Christmas," provoking warm laughter in the court and the judge's cold mask to slip. ${ }^{52}$ When, some weeks later, the appeal judgment is finally delivered, however, the
(C) Author(s), 2016. This open-access work is licensed under a Creative Commons Attribution-NonCommercial 4.0 International license.
Cette oeuvre en libre accès fait l'object d'une licence Creative Commons Attribution-NonCommercial 4.0 International. 
judge deploys the well-worn legal cliché, "I cannot make a judgement based on emotions, I have to look at the facts," before dismissing the asylum claim. ${ }^{53}$ This is after callously describing Alem's mother as having been "hacked" to death, causing Alem to faint in the dock. What Zephaniah sets up in the meeting between the refugee and the law is that of the human before the coldly calculating, a theme that is repeated throughout the novel.

\section{The Return of the Political}

It is at this point, the failure of the appeal, that the story shifts gear. From the cold grey scene of the court, the next chapter is entitled “This Is Politics." Alem's school friends argue with him that a campaign is needed so that he can stay. In the words of one of them, "There ain't no justice, just us." 54 These words are emblematic of a true political subject, one who not only speaks but who does so not on the terms of existing power relations but on those of a collectively self-constituted identity- “just us." Instead of allowing the law to determine the borders of belonging, the community-Alem's schoolmates, friends, foster family, along with the wider community in which he lives-expand it to include someone who in the truest sense of the term is "one of their own." Alain Badiou has coined a slogan to express this political sense of community that cuts across national or legal distinctions: "Everyone who is here is from here." 55 The lines between "them" and "us" have been reconstituted. Instead of a host community/alien binary, we have instead the powerful against all those who are or were once branded as other. Alem's friends present us with a range of these identities. Robert Fern reveals himself at one point to be really Roberto Fernandez, the son of refugees from Pinochet's Chile. Asher, born in Britain to parents from Jamaica, self-identifies as a Rastafarian and thus describes himself as an Ethiopian "who just happens to be born in England." Robert playfully picks up on this when he tells Alem, "All human life started in Africa, so I'm an African too ... an African that just happens to be born in Manor Park." 56 Finally, Ray "Buck" Buckley comes from a family that "had lived in the area as far back as they could trace, but all he wanted to do was leave the area." 57 Buck is, of course, a typical teenager yearning to leave the confines of home and school. But here his typical adolescent angst makes him identify with others who are in other ways outsiders. The community around Alem is suffused with a cosmopolitan working-class culture based on solidarity- "Pithead," the band name of Buck and his mates is a nod to the historically heroic role of the coal miners in the British class struggleand a shared self-constructed identity of belonging together yet feeling alienated from much of "society" as it is reflected in dominant discourses. Alem's friends are thus a perfect example of Said's "affiliation," a conscious process of representation..$^{8}$ Rushdie, in non-fiction mode, has written that all refugee/immigrant communities in England-from the Huguenots, through to the Jews, and more recently, those from South Asia and elsewhere-do in fact have a shared identity as "immigrant Britain," a category that by its nature is constantly in flux. 59

Following the failure of Alem's appeal, this community springs into action in defence of Alem and his father's right to be granted asylum. Initially this creates a schism between father and son. Alem's father rejects the idea of a political campaign in favour of allowing the law to take its course, the argument being that they have no right, as aliens, to engage in politics in the United Kingdom: "We certainly should not be getting involved in the politics of this country."60 This is from a man so deeply involved in the politics of his homeland that he has been forced into exile. The refugee, in other words, once outside of his country of origin, has a right to the law but not to politics. The distinction between "genuine" and "bogus" refugees today is laid precisely on this line between law and politics, for those marked with the imprimatur of the legally constituted refugee subject are allowed (up to a point), whereas those whose claim falls outside, based on a political claim or economic need, are forbidden. Zephaniah's novel breaks through this oppressive binary by contrasting the long, grey, and inhuman legal process with the life and colour of the campaign for Alem's right to stay. Alem, in response to his father's insistence on respecting the line between law and politics argues, "Everything is politics ... We are here because of politics, the judge is there because of politics, and we are being sent home because of politics." Alem's decisive argument with his father is to repeat the quote from his friends: "There ain't no justice, just us."61

The campaign itself displays all the usual contradictory consciousness of those new to political resistance. Statements such as "As British subjects we believe that it is our duty to offer them protection" 62 mingle with slogans of the type, "There are no illegal immigrants, only illegal governments." ${ }_{3}$ The rights of sovereign-constituted subjects confront the placing of legal judgment beyond the realm of the state. A further although undeveloped part of the narrative is the drawing in of other refugees into the campaign. This is shown through the Palestinian Abbas, who turns up at one demonstration with a placard bearing the legend, "Refugees are human, let us live." 64 In this simple but direct demand rests an essential truth of the refugee experience today. Trapped in the one-dimensional identity of the legal subject, forced into a "bare life" of existence, there is the cry for recognition of themselves as multi-faceted political beings in the Aristotelian sense, as members of the polis, the community. A nice example of how the collective and
(C) Author(s), 2016. This open-access work is licensed under a Creative Commons Attribution-NonCommercial 4.0 International license.
Cette oeuvre en libre accès fait l'object d'une licence Creative Commons Attribution-NonCommercial 4.0 International. 
individual subject can interact to (re)construct active subjectivities occurs at a protest for Alem and his father. Called to speak to the crowd, Alem at first resists, nervous and unsure of himself. Only after the calls of the collective for him grow louder does he tentatively take the megaphone and address the protest. In doing so, this refugee literally and figuratively finds his voice.

\section{The Romantic Subject}

One seriously problematic element of Zephaniah's novel is the portrayal of the central character of Alem, the refugee boy of the book's title. He is almost too good to be true. Never once does he behave badly, become unjustly angry or rude. He is the most studious student one could imagine, reading up on the classics of English literature any moment he gets, resisting the temptations of his friends to smoke and act up. In spite of the trauma of having to flee his home, his mother's murder, his father locked up in a detention centre for asylum-seekers, removed from his loving foster family and forced to live in a squalid hostel, humiliated by kids at his school for the gaps in his English, and all the other ritual shaming that asylum-seekers in the United Kingdom face today, Alem remains always calm and welladjusted. He charms the judge and impresses his teachers. His foster mother describes him as a role model whom everyone should look up to. This portrait, like that of Victor Laszlo in Casablanca, is idealized to such an extent that it dulls the contours of the character. Ultimately, Alem comes across as tragic and suffering yet saintly, Christ-like, the ultimate romanticized figure. Thus while the portrait is positive, it remains, like that drawn by law, an image of the refugee that is not truly human. As such he is one of the least convincing characters of the novel. One can understand that Zephaniah wishes to counter the flood of negative images that have swamped our collective consciousness. But as a result we have a character who claims our sympathy on an unreal basis. Alem is the archetypal deserving refugee-hard working, intelligent, respectful, and uncomplicated. Any refugee lacking any or all of these qualities would thus be ipso facto undeserving. Asylum is therefore still predicated on the worthiness of the individual, not on the duty to protect, or the right to sanctuary. We are invited, once again, to sit in judgment on the refugee, even if that judgment is meant to be positive. Just as in the period of decolonization in relation to the nationbuilding migrants, we appear to need our refugees to be heroes in order for them to be valorized or welcomed. We could, perhaps, see the setting up of an idealized refugee such as Alem as an attempt to create an affiliative space that could advance the place of the refugee in the general discourse. But the unreal nature of this central character unfortunately creates a narrative weakness that undermines this objective.

The problem in bringing the ideal to bear in critiquing reality was well described by Georg Lukács. The strength of the novel form, he argued, consists in the "problematic individual's journeying towards himself, the road from dull captivity within a merely present reality-a reality that is heterogeneous in itself and meaningless to the individual-towards clear recognition." 65 This trope is similar to affiliation, as the protagonist struggles with her place in the world, seeking to remake her identity through conscious choices. Zephaniah presents Alem's “journeying” in such a way as to challenge the reality of refugeehood. But the failure to adequately problematize him as an individualwhere "his aims are given to him with immediate obviousness"-makes the transcendence of reality a function of idealism rather than a realist form of immanent critique. ${ }^{66}$ It is important here not to confuse these terms. I use idealism and realism here not as literary forms, but in terms of a philosophical approach to how the dominant discourse can be challenged. Refugee Boy is written in a relentlessly realist register, in the literary sense. But ultimately it falls, through the central character of Alem, into positing an idealized picture of resistance. By contrast, in Rushdie's Satanic Verses, for example, the revolt of the despised immigrant through his transformation into an aggressive beast both brings into sharp relief the bestial imagery that is projected onto the immigrant, while at the same time showing how the most base and animalistic anger is a necessary, if paradoxical, route back to reclaiming his humanity. ${ }^{67}$ Arendt too, in her essay "We Refugees," reflects on the experiences of her fellow exiles from Nazi Europe and draws out all the complex, difficult, and conflicting pressures in maintaining one's identity in a state of forced migration. ${ }^{68}$ The character of Alem fails to present a realistic refugee voice, but he is truly emblematic of the contemporary refugee subject trapped between the tropes of the dehumanized legal definition and the romanticized literary construct. Lukács has further argued that for literature to be successful it "must demonstrate both the concrete and abstract potentialities of human beings in extreme situations." 69 Potentiality is thus not about imagining some idealistic perfection, but neither is it about simply describing subjects just as they are. In a curious way Refugee Boy falls into both these traps-Alem's travails are depressingly familiar, while he appears as a character occupying Malkki's "floating world" of the refugee as victim, painted in the most sympathetic of colours.

\section{Conclusion}

Reflecting upon the literatures of exile, Said has written, "Refugees ... are a creation of the twentieth-century state.
(C) Author(s), 2016. This open-access work is licensed under a Creative Commons Attribution-NonCommercial 4.0 International license.
Cette oeuvre en libre accès fait l'object d'une licence Creative Commons Attribution-NonCommercial 4.0 International. 
The word 'refugee' has become a political one, suggesting large herds of innocent and bewildered people requiring urgent international assistance, whereas 'exile' carries with it, I think, a touch of solitude and spirituality."7o Malkki comments on this passage that the literature of exile to which Said refers, one that "connotes a readily aestheticizable realm," is absent from the field of refugee studies, replaced instead by a focus on "refugees" as subjects of a "bureaucratic and international humanitarian realm."71 However, as Steinbock shows in his study of Casablanca, the romantic construct of an idealized forced migrant has largely informed the international legal definition of the refugee. The exclusion of most forced migrants from the protection of the international legal/bureaucratic order is therefore a result of the fact that the real experiences of most refugees simply do not conform to such an ideal-type. The failure of Alem as a believable protagonist is rooted in this phenomenon. Thus it is a category mistake to counterpose the aesthetic to the legal constructions of the refugee. As Kieran Dolin writes, "The notion that literature is a zone of free expression ... is an idealist one ... Consequently, it is important not to regard literature and law as 'polar opposites,' one a space of freedom, and the other an institution of social control."72 Some way must be found out of a circular discourse based around the legal definition of the refugee and the identity of the nation-state, which continually returns the figure of the refugee to the filiative realm of the objectively good or worthy subject. But as we have seen in the novels discussed in this article, we should not idealize the capacity of literary texts to guide us in this project.

The question of the refugee is political today only in a very restricted sense, framed in terms of a vague humanitarian concern or in the nation-state as a project. The problem evidenced in Exodus and Shame is that once that project of becoming a nation-state is completed, the refugees that remain become ipso facto a non-political question. And in the post-colonial age this is the fate of the overwhelming majority of forced migrants. Instead, if we understand politics as a field of rival positions irreducible to consensus or a final event, then reinvigorating the refugee question involves remaking the refugee subject in such a way that it cuts across the romantic/legal construct.73 Politics in the sense described by Jacques Rancière and Alain Badiou, spaces of contestation that cannot be collapsed into a singular consensus or ethics, has been edged out by a humanitarianism that uses a romanticized figure of suffering as its reference point. Law, on the other hand, by creating categories of rights, and therefore of rights-bearing subjects, reduces the complexities of human beings to "the significance of a mathematical point, a centre in which a certain number of rights is concentrated." 74 In both cases the refugee appears as an idealized trope, which often bears little relation to the difficulties and complexities of the refugee experience. Seeking out the refugee voice is thus about reimagining and rehabilitating the refugee as an active subject, not simply as a victim of circumstances or as an ideal-type. Nevzat Soguk has written of "migratory horizons" in which "migrants make their histories as the histories of others even if 'they do not make them just as they please and under circumstances chosen by themselves." 75 The point is that finding the "true" voice of the refugee is not an end in itself, but rather a process of making and remaking that begins with recognition of the refugee as an active subject at its centre. The problem is that the scope for doing that has become very restricted, as forced migrants are forced to continually confront false images of the refugee constructed by law and the nation-state. ${ }^{6}$ Thus the seeking out of refugee voices is an endeavour that necessarily involves refugees being heard, and therefore having a chance to speak, outside of the frameworks of the nation-state and law. It might be objected that the spaces for doing that are almost impossible to find, or practically non-existent at present. However, by reading the literatures of the distant and more recent past, we can at least see that the refugee has existed in a multiplicity of guises, refreshingly distinct from the pathetic and threatening figure that hegemonizes our discourse today. Yet we must be very wary of relying on the romanticized tropes found in that realm, for all too often they have reflected or fed into, rather than challenged, the existing delineation of the refugee subject.

Simon Behrman is lecturer in law at the University of East Anglia, UK. The author may be contacted at s.behrman@uea. ac.uk

\section{Notes}

1 Ovid, The Poems of Exile: "Tristia," "Epistulae ex Ponto" and "Ibis" (Harmondsworth: Penguin, 1994); Dante Alighieri, The Divine Comedy, 3 vols. (London: Penguin, 2003-7); Daniel Defoe, Robinson Crusoe (London: Penguin, 2007); the poetry of Nazim Hikmet, especially C'est un dur métier que l'exil (Paris: Le Temps des Cerises, 2002); Miguel de Unamuno, "How to Make a Novel," in Novel/nivola (London: Routledge \& Kegan Paul, 1976); in non-fiction, Theodor W. Adorno, Minima Moralia: Reflections from Damaged Life (London: Verso, 1996). Literature in Exile, ed. John Glad (Durham, NC: Duke University Press, 1990) is an edited transcript of a 1987 conference of exiled writers. One theme that is raised by just a few participants, but that is a central concern of this article, is the gap between the experience of the writer in exile and the mass of "ordinary" refugees, with the position of
(C) Author(s), 2016. This open-access work is licensed under a Creative Commons Attribution-NonCommercial 4.0 International license.
Cette oeuvre en libre accès fait l'object d'une licence Creative Commons Attribution-NonCommercial 4.0 International. 
the Gastarbeiters in Germany frequently alluded to in this context.

2 See, for example, Sanford Levinson, "Law as Literature," Texas Law Review 6o (1981): 373-403; Stanley Fish, Doing What Comes Naturally: Change, Rhetoric, and the Practice of Theory in Literary and Legal Studies (Durham, NC: Duke University Press, 1989); Peter Goodrich, Law and the Courts of Love: Literature and Other Minor Jurisprudences (London: Routledge, 1996); Richard A. Posner, Law and Literature, 3rd ed. (Cambridge, ma: Harvard University, 2009); Ravit Reichman, The Affective Life of the Law: Legal Modernism and the Legal Imagination (Stanford: Stanford University Press, 2009).

3 Maria Aristodemou, Law and Literature: Journeys from Her to Eternity (Oxford: Oxford University Press, 200o); Robin West, Narrative, Authority and Law (Ann Arbor: University of Michigan Press, 1993).

4 Kieran Dolin, A Critical Introduction to Law and Literature (Cambridge: Cambridge University Press, 2007), 8.

5 Edward Said, The World, the Text and the Critic (London: Faber, 1984), 19.

6 Ibid., 21.

7 Hannah Arendt, The Origins of Totalitarianism (New York: Schocken, 2004); Liisa H. Malkki, "Refugees and Exile: From 'Refugee Studies' to the National Order of Things," Annual Review of Anthropology 24 (1995): 495523; Philip Marfleet, Refugees in a Global Era (Basingstoke, UK: Palgrave Macmillan, 2006).

8 Benedict Anderson, Imagined Communities (London: Verso, 2006).

9 In Reference Re: Secession of Quebec [1998] 2 SCR 217, a widely cited opinion of the Canadian Supreme Court, it was held that the right of self-determination in international law does not imply an automatic right to secede from another state. The right of territorial integrity of states had to be respected, and so, the court argued, only where basic freedoms were repressed would the right of self-determination entail also the right to form a separate state.

10 Zygmunt Bauman, "Who Is Seeking Asylum-and from What?," Mediactive 4 (2005): 90-107.

11 At the level of international law, the first attempts at regulating refugee status began in the 1920 under the League of Nations and were headed up by the Norwegian diplomat Fridtjof Nansen. They was followed by attempts in the 1930s to draw up legally binding conventions for refugees. The short-lived International Refugee Organisation (IRO) was created in 1946, ending finally with the creation of the United Nations High Commissioner for Refugees (UNHCR), which was established, in tandem with the UN Refugee Convention in 1951. The latter has established a settled system of international refugee law. Domestic laws on refugees have generally been also of twentieth-century vintage and for the last half-century have tended to follow the framework of the un Refugee Convention.
12 For example, in the 1933 Refugee Convention and the 1938 Evian Convention. For detailed discussion of this process, see Claudena Skran, Refugees in Inter-War Europe: The Emergence of a Regime (Oxford: Clarendon, 1995).

13 W.H. Auden, Collected Shorter Poems 1927-1957 (London: Faber \& Faber, 1969).

14 Bernard Porter, The Refugee Question in Mid-Victorian Politics (Cambridge: Cambridge University, 1979).

15 Casablanca, Dir. Michael Curtiz, 1942.

16 Daniel J. Steinbock, "Refuge and Resistance: Casablanca's Lessons for Refugee Law," Georgetown Immigration Law Journal 7 (1993): 649.

17 United Nations, 1951 Convention Relating to the Status of Refugees, Article 1A.

18 Leon Uris, Exodus: A Novel of Israel (London: William Kimber, 1959).

19 The Pale of Settlement was an area in the western Russian Empire in which Jews were granted the right to live. Beyond its borders Jews had very limited rights to reside anywhere else within the empire. The pale was by far the largest Jewish ghetto in Europe from the late eighteenth until the early twentieth century.

20 Uris, Exodus, 229.

21 Ibid., 231.

22 Ibid., 295.

23 Malkki, "Refugees and Exile."

24 Uris, Exodus, 26.

25 Ibid.

26 Ibid., 39.

27 Ibid., 341.

28 Ibid., 30.

29 Ibid., 47. Even today self-organization and political resistance within refugee camps troubles the legal-bureaucratic administration of UNHCR and other agencies that prefer to operate on the basis of the inmates as grateful and passive recipients of aid. See, for example, Guglielmo Verdirame, The UN and Human Rights: Who Guards the Guardians? (Cambridge: Cambridge University Press, 2011), 286; Michel Agier, Managing the Undesirables: Refugee Camps and Humanitarian Government (Cambridge: Polity, 2011), 41.

30 Uris, Exodus, 599.

31 Ibid., 262.

32 Ibid., 546-7.

33 Ibid., 40.

34 Ibid., 235.

35 Ibid., 586.

36 Ibid., 587.

37 Ibid., 605-6.

38 Ibid., 585.

39 Jeremy Salt, "Fact and Fiction in the Middle Eastern Novels of Leon Uris," Journal of Palestinian Studies 14 (1985): 54-63.

40 Salman Rushdie, Shame (London: Picador, 1984).

41 Ibid., 63-4. 
42 Giorgio Agamben, Homo Sacer: Sovereign Power and Bare Life (Stanford: Stanford University Press, 1998), originally published in Italian as Homo Sacer: Il potere sovrano e la nuda vita (Turin: Einaudi, 1995).

43 Rushdie, Shame, 145.

44 Ibid., 66-7.

45 Ibid., 82.

46 Ibid., 85-7.

47 Malkki, "Refugees and Exile," 518.

48 Rushdie, Shame, 267.

49 Benjamin Zephaniah, Refugee Boy (London: Bloomsbury, 2001).

50 British Prime Minister Neville Chamberlain notoriously used this phrase in 1938 to justify his government's washing its hands of any responsibility for protecting Czechoslovakia from the Nazi takeover.

51 Zephaniah, Refugee, 83, 143.

52 Ibid., 150.

53 Ibid., 230.

54 Ibid., 236

55 Peter Hallward, "Badiou's Politics: Equality and Justice," Culture Machine 4 (2002), http://www.culturemachine. net/index.php/cm/article/viewarticle/271/256.

56 Zephaniah, Refugee, 189-9o.

57 Ibid., 123.

58 Said, World, 21.

59 Salman Rushdie, "Imaginary Homelands," in Imaginary Homelands: Essays and Criticism, 1981-1991, 9-21 (London: Penguin, 1992).

6o Zephaniah, Refugee, 238.

61 Ibid., 239-40.
62 Ibid., 253.

63 Ibid., 259.

64 Ibid., 260.65 Georg Lukács, The Theory of the Novel: A Historico-Philosophical Essay on the Forms of Great Epic Literature (Cambridge: MIT Press, 1971), 80; Dolin, Critical Introduction, 41.

66 Lukács, Theory, 78.

67 Salman Rushdie, The Satanic Verses (London: Viking, 1989).

68 Hannah Arendt, "We Refugees," in Altogether Elsewhere: Writers on Exile, ed. Marc Robinson, 110-19 (Boston: Faber \& Faber, 1994).

69 Georg Lukács, Realism in Our Time: Literature and the Class Struggle (New York: Harper \& Row, 1971), 23.

70 Edward Said, "Reflections on Exile," in Reflections on Exile, and Other Literary and Cultural Essays (London: Granta, 2001), 144.

71 Malkki, "Refugees and Exile," 513.

72 Kieran Dolin, A Critical Introduction to Law and Literature (Cambridge: Cambridge University Press, 2007), 41.

73 Jacques Rancière, Disagreement: Politics and Philosophy (Minneapolis: University of Minnesota Press, 1999); Alain Badiou, Ethics: An Essay on the Understanding of Evil (London: Verso, 2001).

74 Evgeny Pashukanis, General Theory of Law and Marxism (London: Pluto, 1989), 115.

75 Nevzat Soguk, "Poetics of a World of Migrancy: Migratory Horizons, Passages, and Encounters of Alterity," Global Society 14 (2007): 431, quoting Karl Marx.

76 Patricia Tuitt, False Images: Law's Construction of the Refugee (London: Pluto, 1996). 


\title{
"We raise up the voice of the voiceless": Voice, Rights, and Resistance amongst Congolese Human Rights Defenders in Uganda ${ }^{\mathbf{1}}$
}

\author{
KATIE R.V. MCQUAID
}

\begin{abstract}
Amongst Uganda's Congolese refugee population are a number of human rights defenders who actively resist the construction of refugees as dispossessed and displaced humanitarian aid recipients. Upon fleeing the complex and violent conflicts of the Democratic Republic of Congo, rather than supplicate to a humanitarian regime saturated with the language of human rights, these young men draw on human rights to "raise up the voice of the voiceless." This article explores how defenders draw on human rights to understand, articulate, and resist the constraints of forced displacement into a humanitarian regime.
\end{abstract}

\section{Résumé}

Parmi les réfugiés d'origine congolaise en Ouganda se trouvent un certain nombre de défenseurs des droits de la personne qui résistent activement à la construction conceptuelle des réfugiés selon laquelle ils seraient tout simplement des bénéficiaires d'aide humanitaire démunis et déplacés. Après avoir fui les conflits complexes et violents qui ont ravagé la République démocratique du Congo, plutôt que d'être réduits à un statut de suppliants envers un régime humanitaire saturé par le discours des droits de la personne, ces jeunes hommes préfèrent puiser dans ces mêmes droits pour "donner voix à ceux qui n'ont pas de voix». Cet article s'engage dans une exploration $d u$ processus selon lequel les droits de la personne peuvent se transformer en terrain fertile qui permet à ces défenseurs des droits de comprendre, d'articuler et de résister aux contraintes du déplacement forcé au sein d'un régime humanitaire.

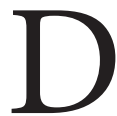
rawing on a long-term ethnographic study of Congolese human rights defenders (HRD) who have fled into Uganda, this article offers insight into the practices and experiences of those who call themselves the "voice of the voiceless," and who are known as "human rights" by the communities they strive to defend. Forced to flee violent persecution for their work as HRD in the Democratic Republic of Congo (DRC), these young Congolese men represent a crucial and under-researched, under-supported, and under-reported part of contemporary Congolese struggles at home and in displacement. This article focuses on the work of these HRD in Uganda, exploring how they draw on human rights to understand, articulate, and resist the constraints of forced displacement into a humanitarian regime.

After setting out the scope of my research and the data upon which this article is based, the first section briefly elucidates the conditions leading to the forced displacement of refugees into Uganda and examines the ways in which defenders themselves come to embody "human rights" for the wider population. The second and third sections focus on refugee life in Uganda, and more specifically the actions of HRD amidst the urban refugee population in Kampala. It draws upon the reflections of several HRD to demonstrate how exercising voice in the pursuit of human rights is about 
more than deploying rights discourses in the construction of political claims and documents. It is about embodied knowledge, using human rights as a critical vehicle for subjectivity, solidarity, and action. It is in engaging with the perspectives of those in the refugee population who regularly draw on human rights language, and who are often the only ones to whom the wider refugee community can turn for information and guidance, that we are compelled, I argue, to confront the contradictions of human rights practice, both in humanitarian work and in defenders' actions. In the final section, this article highlights some of these contradictions through engaging a political understanding of human rights.

This article draws together literatures on both humanitarianism and human rights to consider the multiple ways in which humanitarianism is navigated and contested by HRD using the language of human rights. In particular, it engages with a humanitarian politics centring on notions of victimhood. ${ }^{2}$ Malkki, amongst others, argues how a de-historicizing universalism of humanitarianism creates a context in which it is difficult for people in the refugee category to be approached as historical actors rather than simply as mute victims. ${ }^{3}$ This in turn highlights a general trend in international humanitarianism whereby universalized and standardized identities of suffering are established through personal testimony about international human rights violations. ${ }^{4}$ Many refugees in such contexts end up limited to exercising what Utas terms "victimcy," the agency of hiding one's actions in passive victimhood.5

It is argued that once one is constructed as a humanitarian victim, this subjugated subjectivity of "inarticulate biological life" prefigures any other, ${ }^{6}$ devaluing or gradually robbing people of their agency as self-representations of victimhood lead to a "de-selving" as narratives of strength and resilience are silenced, generating a destructive erosion of subjectivity.7 Whilst Ticktin and others argue that "survivors of violence are silenced as subjects, and as anything other than victims," ${ }^{2}$ stripped of agency, moral conscience, economic potential, or political awareness, ${ }^{9}$ when we broaden our gaze to consider how refuges are engaging with both humanitarianism and human rights, a more nuanced picture begins to emerge. Here, in an ethnographic exploration of the actions of HRD and the shape that "rights"-understood as "rights talk, rights thinking, rights practices" 10 - assume when local discourses of human rights interpenetrate with discourses of humanitarianism, the analytical possibilities extend beyond a critique of victimization and objectification towards a critical engagement with the voices of refugees demanding to govern themselves.

At the centre of this analysis is thus a focus on how HRD engage with what Fassin terms a "humanitarian politics of life," which occurs when a distinction between lives that can be narrated in the first person (those who intervene) is established with lives that are recounted only in the third person (the voiceless in the name of whom intervention is done). ${ }^{11}$ This article examines what occurs when refugees work to trouble this humanitarian politics of life as they strive to reclaim the first person voice as those who intervene from within, and the implications for defenders who seek to operate as "the voice of the voiceless" whilst being simultaneously constituted as voiceless themselves.

\section{Encountering Human Rights Defenders: An Ethnographic Methodology}

The experiences of HRD recounted within this article were shared with me during fieldwork I conducted in Uganda between January 2011 and October 2012. Based mainly in Kampala for this continuous period, I interviewed over three hundred Congolese refugees as part of an ethnographic analysis of refugees' perspectives on violence, humanitarianism, and human rights. This article draws in particular on the narratives of eight Congolese HRD whom I followed closely, including Emmanuel, Fabrice, Patrick, and Pascal, ${ }^{12}$ with whom I established strong relationships over the course of my fieldwork. Their length of displacement varied; Emmanuel arrived in Uganda 2004, and Patrick in 2010. I met these men through my time in the field, discovering the names of individual HRD and the organizations they ran, from refugees who had either heard of or been beneficiaries of their efforts, or introduced to me by others working in the field. Many of these men spoke fluent English, with the exception of Pascal and Patrick, with whom I communicated in a mixture of French and Kiswahili. They had all attained higher education and been active as HRD in the DRC.

They told me their stories gradually and cumulatively and according to their own momentum and logics over time across multiple conversations and interviews. They shared many of their hours talking to me, and inviting me to participate in an extensive scope of voluntary activities they conducted across the dense and frenetic urban spaces of Kampala. As this article demonstrates, their work generated substantial personal risk, and as such their security was paramount, so I took great care to protect their safety, strictly maintaining their anonymity and confidentiality in the field and later in writing up, protecting my research artifacts, and reflecting upon our interactions and the spaces in which we met. A dialogic ethnographic approach was critical in engaging with narratives and memories of violence within forced displacement, and the agency of those who navigate and speak within contentious humanitarian, political, and legal orders.
(C) Author(s), 2016. This open-access work is licensed under a Creative Commons Attribution-NonCommercial 4.0 International license.
Cette oeuvre en libre accès fait l'object d'une licence Creative Commons Attribution-NonCommercial 4.0 International. 
All the HRD I met were men, suggesting a male bias across both the realm of human rights defending and access to education and expert knowledge. I met many women engaged in community work, who were setting up and leading support and community groups. They very rarely, however, represented themselves as HRD, revealing one role that gender plays across the scope of human rights work. Human rights work in this context constituted a particularly male form of habitus, revolving around-to use their own words- "fighting against injustice without fear" and the "leadership or background like men," and whilst passionate advocates of women's equality, HRD also constructed human rights practice as "activities which must do by men," as Patrick put it. I repeatedly overheard Emmanuel telling the young people he worked with, "To start something you have to struggle, to have that vision. A man is one who has faced challenges, [that is] when they can call you a man."

\section{"They call them the law of the people": Congolese Defenders in the DRC}

The DRC has been the site of enduring conflicts on the local and provincial levels since the struggles for independence (1959-65), through thirty-two years of rule under kleptocratic President Mobutu, and the violence of the regional "Congo wars" (1996-7, 1998-2003). The Congolese population have faced protracted political violence engendering frequent forced population displacements both within and over its borders, and the near collapse of the health system and much state infrastructure. ${ }^{13}$ Millions of Congolese are estimated to have been killed through military action, malnutrition, disease, corruption, fighting over management of natural resources, and the inclusion/exclusion of citizenship rights among ethnic groups. ${ }^{14}$ The violence endures, particularly within the east, as many (inter)national protagonists continue to fight in fluctuating patterns of alliance and confrontation. To borrow Taussig's phrase, we might describe how a "state of emergency" faced by many Congolese has become not the exception but the rule, as human rights are violated on a mass scale within the context of individual and communal lives. ${ }^{15}$ Amnesty International reported in 2013 that more than 2.4 million people were internally displaced, and furthermore, hundreds of thousands had been displaced into neighbouring countries.

When I began to ask Congolese refugees about human rights I was repeatedly told that human rights-les droits de l'homme-were people. As one pastor explained, "Human rights: the name says they [are] supposed to protect humans, to talk on behalf of people. It can help people in difficult problem and look for way of solution." Micheline, sitting on a woven mat in front of me, a child slumped asleep across her lap, alongside her brother-in-law Katembo, told me her life story over eight hours, her voice gentle: "The human rights who was speaking on our behalf had been killed, we should just run. He told me, 'This case was politicized.' The reason for his arrestation was this case. He advised me 'to just go in any country, and see how they can help you."'

As she paused, absently stroking the hair of her daughter, my research assistant, a refugee himself, turned to me urgently. "Here the population protects people," he told me, not for the first time. Micheline nodded. Katembo, who had been sitting quietly on the mat next to us, spoke up then to explain how "human rights are trying to help us but also they are fearing, under [the DRC] government. We are just here because we have human rights help us and other organizations try and defend our problems." And who are these "human rights," I asked. "Human rights, these people who are, give someone his rights and also defend people in their circumstance,"16 he explained. Jervais, a man who was forced to flee with his family from Kinshasa told me, "Human rights, from Congo they call them the law of the people. If I get a problem I go to the human rights, and they go. I don't have power, or no gun to fight [the Congolese] Government. Police can do nothing."

For much of the population of eastern DRC, my informants suggested that "human rights" refer not to abstract legal categories, but to the men who strive to protect and defend them in a landscape of violence and impunity. They are the individuals they hear about from their neighbours, listen to on the radio, or see active within civil society. Where "police kill people," they are the men who travel through perilous terrain to record and denounce massacres, who visit prisons and rebel groups, who stage marches and protests, who send detailed and meticulously researched reports to international and national agencies. In seeking to find loved ones who have disappeared, to appeal against violations sweeping through their communities, to make claims for justice and accountability against those perpetrating violence with impunity, these are the people who do not just act to "defend" people, to "give" them their rights, but they also come to inhabit the discourses that they deploy. They "are" human rights to the population.

This was exceptionally dangerous work. One man told me, "We are just in a hole in Congo, the population cannot raise their voice. There is no democracy. Any time you can just die." "So human rights defenders are raising their voices?" I asked. He frowned, "Human rights could help people but they are silenced by the [Congolese] government. The government are silencing human rights." Awezaye, rescued from a rebel group by an HRD, described how "one human rights worked a lot, one sacrificed his life to talk on behalf of many. That is the reason he was killed, because he was defending many people. He was a very good man." 
In contrast to how they were perceived in the population, these "human rights" referred to themselves strictly as "human rights defenders." These were, I was told by Fabrice, an HRD from Bukavu, South Kivu, "those who are supposed to talk on behalf of others who don't have the power or means of talking, the voice of the voiceless." When I asked who the "voiceless" were, the common response was simply, "They do not have the strength." In describing their work and selves, HRD thus used a different but no less embodied language to describe their work. Pascal was one such man. He was twenty-five and had fled the DRC five years previously after facing brutal persecution for his rights work. The first time we met, he introduced himself as an HRD: "You have first to know, this work of being a human rights defender, it must be voluntary first, it must come from you. I do it because I want to do it, it is my nature, it is in my blood. You must be willing to do this work."

He nodded as he spoke, running his fingers along the neatly divided papers of a folder in his lap comprising human rights reports he and colleagues had meticulously researched and written, interspersed with copies of (inter) national legislation. He continued, pointing his finger in emphasis, eyes wide in his small face: "Despite the fact that everyone fears to die, as human rights defenders you are aware of risk. If you sacrifice yourself you are not afraid. It is voluntary, no one is pushing you to do it, you sacrifice yourself to help others. I cannot say everyone, but sure there are others like me. I know some, we work together."

One of those he worked with was Fabrice, who in another conversation explained that being an HRD "is not [only] what you are, it is what you do." Didier, in his thirties, was a prominent refugee leader when I met him. He had been engaged in rights work in DRC for seven years before fleeing to Uganda. Meeting in the ramshackle shed used by his community organization as a classroom for refugee children in Kisenyi, he described being an HRD: "It is nature, be born with it. A humanitarian heart, [you] must have it in your nature. Be the voice of the voiceless. For me to be human rights defender, I discover myself, what is in my capacity of doing things? What is my rights? How to defend?"

For Justin, also in his thirties, defending was "all about passion, connections, help. We are trying to work, to see, we have hope things will change. To be the voice of the voiceless."

\section{Defending in Displacement}

The DRC's enduring violence has ensured that there is an accompanying protraction of displacement into neighbouring countries, where Congolese refugees find themselves at odds with the framework of emergency and short-term crisis that dominates many of the region's humanitarian interventions. The United Nations High Commissioner for Refugees (UNHCR) reported in 2013 that there were approximately 118,ooo registered Congolese refugees/asylum seekers in Uganda, ${ }^{17}$ but the true number was likely to be much higher. Upon arrival in Uganda, Congolese became bound by the Refugees Act 2006, a piece of legislation described in one humanitarian report as "progressive [and] human rights and protection oriented." 18 The current refugee policy in Uganda according to this Act and UNHCR policy is "premised on two pillars: the settlement policy and the self-reliance strategy (SRS). Under the former, refugees are required to reside in designated settlements, all located in remote, rural areas." ${ }^{\prime 19}$ Here they are eligible for material assistance, whereas under the latter, those refugees living outside of such settlements are not provided with any material assistance." ${ }^{20}$ In response to the hardships and restrictions associated with the settlements, tens of thousands of refugees decide to "self-settle" amongst the national population in border areas and the capital. ${ }^{21}$ The refugees I encountered had fled into a humanitarian space characterized by the widespread and systemic violation of critical refugee rights, particularly relating to welfare, freedom of association and expression, and work, in which durable solutions continue to remain elusive for the vast majority. ${ }^{22}$

Urban refugees live largely in the many slum belts of Kampala. Forced displacement from a long-term conflict zone, coupled with life in Kampala's slums, ensured many refugees faced multiple and complex needs, finding it difficult to secure permanent employment and places for their children in schools, and living in substandard housing with poor sanitation and security. Many exhibited complex health issues arising from violence experienced in the DRC and often years of poor, if any, medical treatment. Attending Ugandan humanitarian agencies thus became part of the daily routines of many, as they could often represent the only route to attaining health, legal, material, educational, and other necessary assistance. To access such humanitarian assistance and incite the empathy of strangers and Good Samaritans alike, many refugees had little choice but to engage in "victimcy," performing particular frames of victimhood and vulnerability, and repressing resilience, creativity, and action as they worked to conform to the behaviour of "true refugees" that humanitarian officials might consider credible. ${ }^{23}$ As Emmanuel wryly explained, when "going to [humanitarian] offices you put bad clothes, look like you're going to die today.” In Kampala, as refugees engaged in strategic essentialism to produce their own victim identity they were, HRD argued, in danger of losing a sense of both self and hope. Patrick articulated this one day, sighing as he rubbed his moustache, "Refugees think everything is finish for them." One young widower called
(C) Author(s), 2016. This open-access work is licensed under a Creative Commons Attribution-NonCommercial 4.0 International license.
Cette oeuvre en libre accès fait l'object d'une licence Creative Commons Attribution-NonCommercial 4.0 International. 
Julius was not alone in telling me, "For sure, when I consider the kind of life in Uganda, this is not the life a human being can go through. Since I am in Uganda life stopped for me."

The staff with which refugees interacted were overwhelmingly Ugandan, and this predominance of Ugandans working in what appeared to be an unwieldy, bureaucratic humanitarian machine augmented for refugees an entrenched divide between humanitarians and refugees, distancing refugees from the decision-making processes over their own cases, fuelling anxieties around documentation, and contributing to a culture of distrust that embittered many of the relationships between humanitarians and refugees. It also led to much frustration amongst those who had engaged with and conducted humanitarian work in the DRC for local, national, and international non-governmental organizations, particularly HRD, who decried both the lack of opportunities for refugees to secure employment and opportunities within the humanitarian realm.

In addition to their perceived inaccessibility, the regime was believed to be actively frustrating the attempts of refugees to help themselves, and refugees were thus forced to look to their own community for help. As one woman explained, "Here, yes, whenever you have insecurity problem, you can report to police, which cannot happen in Congo, but when you report you cannot get assistance. They do not protect everyone." Her eldest daughter, at sixteen, agreed: "[Humanitarian] refugee organizations-whenever you go there, they will listen to you and tell you what you are supposed to do, but they will not take any action." Further to this, her mother added, Ugandan human rights organizations "also they say that [there is] nothing [they] can do to assist us since we have organization dealing with refugees, and then refer us to the [refugee] office[s]." Therefore, as Patrick, an HRD, observed, "People are aware, since they fail to get assistance from any organizations working with refugees, they come to us." Congolese HRD were, in contrast, seen to be accessible and approachable. Embedded within their own communities, they were observed using the language of human rights to try to both ameliorate and seek redress for the suffering of refugees.

It never took long for HRD to re-engage in rights work in Uganda, mostly through the creation of community-based organizations. All the HRD I met were adamant that "there was no other work" for them "in this world." As Fabrice said of his arrival into Uganda, "Still I continue to work for human rights wherever I am going. I like being an advocate, to defend human rights until my death ... We human rights defenders, we have to take those issues."

For him it was the suffering he witnessed amongst refugee women, especially in the rural refugee settlements, that impelled him into action. He spoke passionately of the widespread lack of justice and protection for refugee women who had suffered sexual abuse. These women, isolated in the settlements, had little sympathy from local police, and no financial resources or knowledge of their rights to escalate or politicize their cases. Alongside "a colleague" he formed an organization and began to conduct research. He explained, "We interviewed many women, many of them are raped and there was no organization to defend. For us the field was just refugee women, it was the focus. We really made several campaigns. We had some recommendations, so many recommendations. We published a report that women were traumatized in Uganda. We saw many human rights concerns. We make actions. I have partners from Congo, I knew how to communicate to them, [for example] the African Commission for Humans and People's Rights. The [Ugandan] government was asked to report to ACHPR in 2009 on issues in that report."

In March 2009 Fabrice was invited to "present the experience of women" during an event for Sexual and GenderBased Violence (sGBV) Week in Kampala, sponsored by local humanitarian agencies working with refugees. He was told "the police, opm [Office of the Prime Minister], Ugandan authorities, UNHCR be there":

As human rights defenders we must present issues to them. My wish is the authorities hear women are suffering, must do something. I prepared twenty cases. It was a big seminar, they invited many partners. I went there, I presented human rights violations case by case. I show this case violated this article, this contravenes such articles. On the tenth case, all the cases are presented to show the police are responsible for human rights violations directly or indirectly. Now, on the tenth, I saw the police inspector get the police and said I should stop: [he said] "They abuse the police."

In using the language of rights to (re)construct the experiences of these refugee women into human rights violations, Fabrice claimed a legal subjectivity not just for them, but also for the refugee community as a whole. Social connections were critical. For many refugees, traditional and essential ties of kinship and community are fractured in the course of flight, rendering them isolated and vulnerable. The powerful and desperate realities of their persecution in the DRC aside, HRD had, like those they helped, arrived in Uganda with little or nothing, actively living and understanding the violence, disruption, and insecurity interwoven through the fabric of everyday life. Unlike most, however, they had the tools with which to reinscribe such complaints. Operating through diligent (re)constructions and interpretations of rights discourses within a visible public realm, their production and dissemination of reports constituted internationalized forms of fact-finding
(C) Author(s), 2016. This open-access work is licensed under a Creative Commons Attribution-NonCommercial 4.0 International license.
Cette oeuvre en libre accès fait l'object d'une licence Creative Commons Attribution-NonCommercial 4.0 International. 
protocols in which human rights abuses were codified within standardized, often chronological formats. ${ }^{24}$ In so doing, for example, Fabrice became a conduit for these women to know and claim for their rights, exercising a narrative authority derived from experience, knowledge, and a position within both horizontal networks-as a refugee himself with access - to listen to these women, and vertically, within international and regional rights networks. They incorporated individual experiences into their own collective voices in speaking up to the Ugandan government, humanitarian regime, and regional rights platforms, implicating the international in the local.

\section{"You try to change the situation, that is human rights activity"}

Beyond classical human rights work of conducting research and gathering evidence within meticulous reports cataloguing human rights violations, HRD also conducted numerous practical activities to fill the service gap often left by humanitarian agencies. Their community-based organizations were not prominent in the humanitarian field in attracting funding and were often instead marginalized by more established nationally run (and internationally funded) humanitarian agencies. Nevertheless, they were well attended, respected and relied upon by the refugee community, occupying a critical hub for many men, women, youth, and children.

Their work could include helping people to negotiate the different humanitarian agencies and mandates, working out which agency offered which services, and sometimes accompanying refugees to Old Kampala Police Station or OPM when seeking asylum, or to local police posts whenever they had a complaint, such as robbery or assault. Many offered free English classes to all levels of competence, and some offered vocational training in different livelihood or computer skills for those across the refugee community. HRD could also help individuals and families seek sponsors, write letters, find health care and medication, or temporary and permanent places to live, and make connections across the community. Many offered counselling services or ran outreach activities such as gender-based violence programs. This work took on many guises yet was referred to under the umbrella of "that human rights" by both HRD and nondefender alike.

A charismatic man of twenty-six, Emmanuel had a forceful personality. Often clothed in bright colours, he could command any space. He had been active as a law student in Bukavu's civil society, “defending human rights, abuses of government soldiers, we sent reports to MONUC"25activities that brought him "into conflict with government soldiers.” Faced with certain incarceration and/or death,
Emmanuel fled to Uganda in November 2004. Early in 2005, upon being granted refugee status, he was sent to Kyaka II refugee settlement where, aged twenty, he felt impelled to organize a group of young people to come together in protest. He explained, "I could not stay like that-no jobs, abuses of rights, commandant beating women, taking refugees as dogs. I was so popular in the camp, constructing latrines, [organizing] a championship of soccer. I was like community leader, like I am in Kampala today."

He formed an association that "wrote so many things, writing, lobbying, reports ... our purpose to show the rights of refugees need to be respected." As for Fabrice, Emmanuel sought to claim a position from which he could speak against those discursively constituted as the powerful interveners - the "practitioners of humanity." ${ }^{26}$ He recounted how it was his "heart of human rights" that drove him to continue "fighting against wrong people in the system," even when now fighting those belonging to an altogether different system.

As a consequence, he was repeatedly attacked and detained by the settlement authorities. He was beaten, and the commandant falsely accused him of abduction in a bid to detain and silence him, part of a campaign through which he "became a bad name." He began to "hide," sleeping in a different house every night before escaping the settlement and walking for two days to a nearby trading centre and into the relative anonymity of Kampala. Rather than being silenced, however, all this had the opposite effect. Almost six years later he was pragmatic about how these events prompted him to take more care in framing his reports to "speak about good and bad points. [If] human rights activities put you in conflict, [you] try to change strategy." His work was nowadays conducted through a deliberately crafted trail of stamps and paperwork, drawing a self-protective bureaucratic shield around his activities. His passion for helping young refugees surged unabated, his focus now turned to "home care," providing shelter, education, medical help, and counselling for "unaccompanied minors." He operated with energetic zeal, directing his passion into helping young people to transform themselves away from what he called "that mind of despair." As he explains, "My project is to help remove that mind. Uganda is a very good country, you can do what you want, you are a refugee just in documentation. You try to change the situation, that is human rights activity.

Emmanuel was not alone in highlighting the emancipatory potential of human rights. Justin was another HRD who spoke of being driven by his desire to "raise up young people." Tireless at thirty, he was always on the move, hurtling between voluntary activities of his vibrant community organization. He described how "people have to think how
(C) Author(s), 2016. This open-access work is licensed under a Creative Commons Attribution-NonCommercial 4.0 International license.
Cette oeuvre en libre accès fait l'object d'une licence Creative Commons Attribution-NonCommercial 4.0 International. 
to make yourselves free, the government is not doing anything, the elections are the same, promises from government, nothing has changed." His work "to empower dispossessed young refugees" was critical, he argued, "to overcome the burdens of deprivation and vulnerability to become healthy, educated, self-sustaining and contributing members of society ... I give them hope, show them everything is possible."

Peter, who worked closely on occasion with Pascal, explained such an approach: "Refugee-led organizations play a big role, they change the picture of local perception, they give a totally different perception-refugees solving problems of being refugees. Refugees are made part of development, they are partners."

Nyamnjoh argues that there can be a tendency in the uptake of human rights in local spaces to minimalize the power of society, social structures, and communal and cultural solidarities, ${ }^{27}$ whilst Merry warns of how when local activists use a language legitimated by a global consensus on standards, this political space can come at a price. Human rights can displace alternative visions of social justice that are less individualistic and more focused on communities and responsibilities, possibly contributing to the cultural homogenization of local communities. ${ }^{28}$ This article demonstrates how in Congolese HRD in Uganda, almost the opposite is true. Whereas the humanitarian regime-and its language of human rights-is seen by refugees as inaccessible and repressive, when rights are reclaimed and wielded by HRD from within they are seen to hold real potential for articulating and challenging local and humanitarian power structures, and promoting communal and cultural solidarities. Ideas of human rights are used by HRD to promote individual and collective autonomy and establish new forms of social relations concerned not with dependence on aid or humanitarian assistance, but aspirations to self-governance and sustainability. A critical engagement with local rights vernaculars to navigate humanitarianism extends our understanding of the multiple and rich ways refugees experience, understand, and resist the subjugation of humanitarian aid. Yet these too are enmeshed within webs of entrenched inequalities, requiring attention to their own inner contradictions.

\section{"Human rights activities put you in conflict": Contradictions in Human Rights}

This final section examines how local cultures of rights are entangled in power and voice: who can and cannot speak, what they can say, and how their words are shaped and received. Goodhart observes how in certain situations human rights can be contentious, reflecting and reinforcing particular power and privilege at work. ${ }^{29}$ A political understanding of human rights here can draw attention to an important distinction between their use in emancipatory work, and their "misuse" as a means for domination and oppression. A focus on the contradictions arising in the human rights landscape reveals how human rights can be used as a tool for marginalisation and enforcing social hierarchies, or obstructing those already disempowered from the ability to articulate their grievances. ${ }^{30}$

HRD were quick to recognize, name, and denounce the relations of power and subjugation within what they tellingly called the "refugee management system," contesting the failings of a humanitarian regime that was paradoxically saturated with the language of rights. In spite of, perhaps even because of, the efficacy of their actions, HRD-in their work to invoke the responsibilities of those in authority to defend, rather than violate, the rights of refugees-encountered both domination and oppression across multiple levels. One form this took was through formal political exclusion enshrined in law, ${ }^{31}$ whilst another arose within informal interpretations of the "political."

Rights practice was frequently interpreted and inscribed as political by those in authority-whether humanitarian or state actors-leading to the marginalization of HRD. Pascal told me about one case he had taken on. He had worked with a woman whose thirteen-year-old granddaughter was "defiled" by a Ugandan man who was granted police bail after his family gave money to the police post where he was jailed. He explained, "When we saw the case is very bad, we decided to publish and talk to the [police] authorities who have power, we don't have power. We are following the case and are in danger." He was accused of being "engaged in politics" and threatened with arrest himself. Such marked power inequalities described by Pascal created the conditions in which quotidian rights work was recast by those in authority as "political," allowing for and sanctifying the oppression and silencing of defenders and refugees more widely. Pascal pointed out the irony of such accusations levelled at those most legally literate: "How can we engage in political activities when we are refugees here? The law in the country of asylum is that we cannot be political. We do not want to be involved in politics."

In their simultaneous use and condemnation of human rights, the Ugandan government could thus deploy the language of human rights in its discourse of refugee protection to international donors, whilst at the same time portraying HRD as illegally engaging in "politics." This effectively demonized them as being antagonistic to the government who had benevolently provided them with "refuge," revealing how human rights can be (mis)used by agents of domination to disempower, marginalize, and silence those who denounce them. Many HRD were overtly critical of the implication of the humanitarian regime within the Ugandan
(C) Author(s), 2016. This open-access work is licensed under a Creative Commons Attribution-NonCommercial 4.0 International license.
Cette oeuvre en libre accès fait l'object d'une licence Creative Commons Attribution-NonCommercial 4.0 International. 
government, observing a contrast to their experience of navigating humanitarian operations in eastern DRC. "The UNHCR is under government" was a constant refrain in our conversations. Months after I met Patrick, he revealed this darker side to defending. In "making lives better" he was aware that, as a result of his activities, "the Ugandan govern ment is involved. They now don't want any organization to resettle us. To live has become a big problem." When I asked him how he did continue to live he shrugged, "What remains for us is courage, otherwise we would not survive." Fabrice offered further reflections on this repression: "In Uganda the resisting force is the government. They are resisting the activity of human rights defenders. These governments, they are the ones responsible for human rights violations, directly or indirectly. We try to denounce these issues ... When we denounce we get a big problem, in all of Africa."

It is not just in the disciplining of defenders' voices that we can observe such contradictions in human rights practice. Not even two years after fleeing Bukavu for his life, Fabrice found himself entering a new nightmare in the aftermath of his public denunciation of the police in 2009: "We first started receiving threats by telephone. Eh! When we saw that, Amnesty International advised us to keep a low profile, we start managing our security." One month later Fabrice was abducted from his house and taken into custody. Arms bound behind him and his feet tied together, he was badly beaten in the vehicle before arriving at one of Kampala's notorious "safe houses." Here he was interrogated and tortured, his assailants demanding, "Why did you publish this information to the international community? Why are you making malicious against the government of Museveni?" Curled up against their blows, he still protested, crying, "For us we carry out investigation and publish reports, we want voices of refugee women to be heard by you and the international community so their human rights be respected.' Unsatisfied, his interrogators continued to torture him.

To this day he does not know how the events unfolded exactly, but he was released after three days of illegal detention and torture, during which he was repeatedly threatened with death. He showed me two reports, explaining, "Frontline [Defenders] already published. The international community made pressure to the government." After receiving emergency treatment, he found a safe refuge. Vulnerable and facing intense precarity, Fabrice appealed to the UNHCR for assistance in leaving Uganda. However, as he recounts, "UNHCR now saw this case was against their priorities, they are like to work under government. They feared to work on my case, they could not protect me. Other organizations request them to resettle me. UNHCR said they could not, they gave me a rejection letter! That is terrible really."
His case reveals both an abuse of power and a failure in protection, but also the difficult intermediary position of humanitarian agencies, a kind of "double bind" experienced by organizations problematically positioned between the state and the members of vulnerable populations whose rights they ostensibly seek to protect. ${ }^{32}$ More crucially, however, is the precarity of those who operate both within this gap and as members of such a vulnerable population, often forced into a position of heightened vulnerability as those in intermediary positions reside in non-action.

Yet more troubling still is the role of these intermediaries in repressing those who attempt to speak out. A violent and corrupt police force aside, many HRD attested to the deep implication of the humanitarian regime in their suppression. Pascal told of how he and others had been repeatedly persecuted by the humanitarian actors whose weaknesses in responsibility to protect refugees' rights they sought to voice: "When you come out and speak openly to the international community you will become a target. They are organizing meetings against those talking about violations of human rights." I asked who "they" were. "I'm talking about InterAid, Office of Prime Minister, UNHCR, who meet to fight those who are talking about human rights violations. You see it will affect them one way or another. A refugee can go to meet you about his problem, to report a case, he can be arrested there. Human rights activities put you in conflict. While no protection of human rights, abuses continue."

Many others spoke of meetings in which defenders were unequivocally told to "be quiet and stay down" or their case files would be closed and any potential humanitarian assistance-particularly resettlement-revoked. This had happened to Peter, who wearily explained, in echoes of Emmanuel's experience in Kyaka II, "When you try to tell them about the rights of refugees they take you as a bad person."

It was not just within the humanitarian regime that the values of human rights were inconsistently supported. Whilst working tirelessly for the emancipation of some sectors of the refugee community, certain HRD were exercising their own power and exclusive privilege in repressing particular social and minority groups. As Englund cautions us, critical analysis of international human rights activism "subverts its own objectives if it does not include activists' contradictory position in regard to human rights." 33 Didier represents an (extreme) example of the messy and often hierarchical nature of rights work. It was only after knowing each other for several months that I discovered he was playing an active role in a campaign against what he referred to as "another problem now in our community"-that of "homosexuality." He was assertive in arguing how "in our community it cannot be acceptable, so we cannot allow it." Whilst representing a minority amongst the HRD I met in
(C) Author(s), 2016. This open-access work is licensed under a Creative Commons Attribution-NonCommercial 4.0 International license.
Cette oeuvre en libre accès fait l'object d'une licence Creative Commons Attribution-NonCommercial 4.0 International. 
Uganda, especially when compared to others actively campaigning for minority rights, his case certainly reminds us to consider the rhetoric of HRD critically.

Niezen points to how whilst the central goal of human rights is "to better the conditions of those who are most blatantly victimized by states, it in practice empowers those who are most visible to publics." 34 Jamal, a young man who had fled to Kampala from persecution in a refugee settlement, told me how Congolese HRD "don't help LGBTI, 35 and also in Congo they don't support LGBTI people ... I tried to meet some human rights, he said he cannot follow that case. In practice, they choose some people, but they say they defend the human rights of all people. They are not defending, they marginalize us."

Jamal's words highlight the importance of interrogating the very notion of "the voiceless" evoked frequently, and uncritically, by HRD, to uncover the hierarchies and exclusions embedded within it. ${ }^{36}$ In being "the voice of the voiceless" HRD were paradoxically replicating the anonymity and invisibility generated by structures of oppression whilst simultaneously posing a challenge to it as highly visible and empowered agents. Whilst striving to have refugees' struggles seen and heard, they were simultaneously suppressing these same voices as they spoke on their behalf. In assuming such a visible position, however, they placed themselves at extraordinary risk. It might be unsurprising therefore, that for the wider population, the authority to "voice" human rights was rarely considered their own. Human rights, rather than inalienable rights belonging to every person, were instead conceived largely as not tools wielded by select, educated others, but as embodied in the HRD themselves.

\section{Conclusion}

An ethnographic account of Congolese HRD in Uganda offers insight into the competing discourses and articulations of power of those in positions of authority (humanitarians and state agents), the subjects of such power (refugees), and those subjects who resist power from within (human rights defenders). This analysis engages with and pushes beyond the significant theoretical and empirical literature on humanitarianism and human rights by drawing the two together. This not only provides a richer understanding of how humanitarianism and human rights are understood and articulated, but also resisted and subverted by those facing protracted forced displacement. It uncovers, in the process, the nuance and contradictions of local cultures of human rights in practice and reveals the underbelly of a humanitarian system using the discourse of rights to morally justify and animate their activities whilst simultaneously driving a regime that objectifies, depoliticizes, and marginalizes refugees.
HRD draw our attention to how humanitarianism violently occludes vulnerable people from the discursive and legal resources to communicate and politicize their subjugation. In refugees' perspectives, however, human rightsas enshrined not in law or text, but in the actions of Congolese HRD-were perceived to enduringly hold distinctly more emancipatory potential in remaking worlds than any humanitarian policy or practice. Here human rights are seized upon as a language for not only critiquing the culture of powerlessness at work in Uganda's humanitarian regime, but also for framing the action taken to resist such subjugation and to promote individual and collective autonomy. HRD work to establish new forms of social relations concerned not with being dependent on aid or humanitarian assistance, but aspirations to self-governance. Such ideas and those who wield them are certainly problematic and are indeed enmeshed within their own webs of entrenched inequalities, yet a critical engagement with local rights vernaculars and other means for navigating humanitarianism extends our understanding of the multiple and rich ways refugees experience, voice, and resist the subjugation of humanitarian regimes.

Katie McQuaid is research fellow at University of Leeds. The author may be contacted at k.r.v.mcquaid@leeds.ac.uk.

\section{Notes}

1 An early version of this article was presented at "Refugee Voices: Refugee Studies Centre International Conference," Oxford, UK, 24-5 March 2014.

2 M. Duffield, Development, Security and Unending War: Governing the World of Peoples (Cambridge: Polity, 2007); D. Fassin, and M. Pandolfi, Contemporary States of Emergency: The Politics of Military and Humanitarian Interventions (New York: Zone Books, 2010); T. Kelly, This Side of Silence: Human Rights, Torture, and the Recognition of Cruelty (Philadelphia: University of Pennsylvania Press, 2012); D. Kennedy, “The International Human Rights Movement: Part of the Problem?," Harvard Human Rights Journal 15 (2002): 101-25; D. Meyers, "Two Victim Paradigms and the Problem of "Impure' Victims," Humanity: An International Journal of Human Rights, Humanitarianism, and Development 2, no. 2 (2011): 255-75.

3 L. Malkki, "Speechless Emissaries: Refugees, Humanitarianism, and Dehistoricization," Cultural Anthropology 11, no. 3 (1996): 378 .

4 C. Colvin, "Ambivalent Narrations: Pursuing the Political through Traumatic Storytelling," Political and Legal Anthropology Review 27, no. 1 (2004): 72-89; K. Sandvik, "International Law and Security," in The Routledge Handbook of New Security Studies, ed. J.P. Burgess (London:
(C) Author(s), 2016. This open-access work is licensed under a Creative Commons Attribution-NonCommercial 4.0 International license.
Cette oeuvre en libre accès fait l'object d'une licence Creative Commons Attribution-NonCommercial 4.0 International. 
Routledge, 2010), 4; K. Segall, "Postcolonial Performatives of Victimization," Public Culture 14, no. 3 (2002): 617-19.

5 M. Utas, "West Africa Warscapes: Victimcy, Girlfriending, Soldiering: Tactic Agency in a Young Woman's Social Navigation of the Liberian War Zone," Anthropological Quarterly 78, no. 2 (2005): 409.

6 G. Agamben, Homo Sacer: Sovereign Power and Bare Life (Stanford, CA: Stanford University Press, 1998).

7 M. Hajdukowski-Ahmed, "A Dialogical Approach to Identity: Implications for Refugee Women," in Not Born a Refugee Woman: Contesting Identities, Rethinking Practices, ed. M. Hajdukowski-Ahmed, N. Khanlou, and H. Moussa (New York: Berghahn Books, 2008), 40; P. Kea and G. Roberts-Holmes, "Producing Victim Identities : Female Genital Mutilation and the Politics of Asylum Claims in the United Kingdom," Identities: Global Studies in Culture and Power 2O, no. 1 (2013): 99; H. Ghorashi, "Agents of Change or Passive Victims: The Impact of Welfare States (the Case of the Netherlands) on Refugees," Journal of Refugee Studies 18, no. 2 (2005): 181-98; S. Jensen and H. Ronsbo, eds., Histories of Victimhood (Philadelphia: University of Pennsylvania Press, 2014); R. Zetter, "Labelling Refugees: Forming and Transforming a Bureaucratic Identity," Journal of Refugee Studies 4, no. 1 (1991): 39-62.

8 M. Ticktin, "Sexual Violence as the Language of Border Control: Where French Feminist and Anti-Immigrant Rhetoric Meet," Signs: Journal of Women in Culture and Society 33, no. 4 (2008): 884.

9 C. Nordstrom, Girls and Warzones: Troubling Questions (Uppsala: Life and Peace Institute, 1997), 36.

10 J. Cowan, M. Dembour, and R. Wilson, eds., Culture and Rights: Anthropological Perspectives (Cambridge: Cambridge University Press, 2001), 11-14.

11 D. Fassin, "Humanitarianism as a Politics of Life," Public Culture 19, no. 3 (2007): 519.

13 L. Roberts, Mortality in Eastern DRC: Results from Five Mortality Surveys by the IRC (Bukavu: DRC, 2000).

14 International Rescue Committee and Burnet Institute, Mortality in the Democratic Republic of Congo (2008), http://www.rescue.org/sites/default/files/resourcefile/2006-7_congoMortalitySurvey.pdf.

15 M. Taussig, The Nervous System (London: Routledge, 1992), $10-34$.

16 Emphases added.

17 UNHCR Uganda, "2015 UNHCR Country Operations Profile: Uganda," http://www.unhcr.org/pages/49e483co6.html.

18 Refugee Law Project, Refugee Law Project Critique of the Refugees Act (2006), 3.

19 C. Clark-Kazak, Recounting Migration: Political Narratives of Congolese Young People in Uganda (Montreal and Kingston: McGill-Queen's University Press, 2011), 31-2.

20 L. Hovil, "Self-Settled Refugees in Uganda: An Alternative Approach to Displacement?," Journal of Refugee Studies 20, no. 4 (2007): 568-9.
21 Ibid., 601.

22 M. Sharpe and S. Namusobya, "Refugee Status Determination and the Rights of Recognized Refugees under Uganda's Refugees Act 2006," International Journal of Refugee Law 24, no. 3 (2012): 562; Hovil, "Self-Settled refugees," 599.

23 M. Utas, "West Africa Warscapes"; E. Friedman and R. Klein, Reluctant Refugee: The Story of Asylum in Britain (London: British Library, 2008), 59.

24 W. Hesford and W. Kozol, Haunting Violations: Feminist Criticism and the Crisis of the "Real" (Chicago: University of Illinois Press, 2001), 5.

25 Mission des Nations Unies au Congo-the United Nations mission in DRC at the time.

26 A. Ong, Neoliberalism as Exception: Mutations in Citizenship and Sovereignty (Durham, NC: Duke University Press, 2006), 198.

27 F. Nyamnjoh, "Reconciling 'the Rhetoric of Rights' with Competing Notions of Personhood and Agency in Botswana," in Rights and the Politics of Recognition in Africa, ed. H. Englund and F. Nyamnjoh (London: Zed Books, 2004), 33.

28 S. Merry, Human Rights and Gender Violence: Translating International Law into Local Justice (Chicago: Chicago University Press, 2006), 4.

29 M. Goodhart, "Human Rights and the Politics of Contestation," in Human Rights at the Crossroads, ed. M. Goodale (New York: Oxford University Press, 2013), 34.

30 Ibid., 36,38 .

31 Under "Part V: Rights and Obligations of Refugees" of the Refugee Act 2006, this is referred to twice, under Article 29: Rights of Refugees while in Uganda, 1 (g) where it says refugees "have a right of association as regards non-political and non-profit making associations and trade unions," and in Article 35: Duties and Obligation of Refugee, which goes into more detail on not engaging "in any political activities within Uganda, whether at local or national levels," or undertaking "any political activities within Uganda against any country, including his or her country of origin."

32 D. Goldstein, "Whose Vernacular? Translating Human Rights in Local Contexts," in Goodale, Human Rights at the Crossroads, 114 .

33 H. Englund, Prisoners of Freedom: Human Rights and the African Poor (Berkeley, cA: University of California Press, 2006), 8, 145.

34 R. Niezen, "The Law's Legal Anthropology," in Goodale, Human Rights at the Crossroads, 196.

35 Lesbian, gay, bisexual, transgender, intersex.

36 I examine the case of Congolese refugees belonging to sexual and gender minorities elsewhere. See K. McQuaid, "Violent Continuities: Telling Stories of One Sexual Minority Life in the African Great Lakes region," Identities: Global Studies in Culture and Power 21, no. 5 (2014): 570-85.
(C) Author(s), 2016. This open-access work is licensed under a Creative Commons Attribution-NonCommercial 4.0 International license.
Cette oeuvre en libre accès fait l'object d'une licence Creative Commons Attribution-NonCommercial 4.0 International. 


\title{
"Refugee Voices," New Social Media and Politics of Representation: Young Congolese in the Diaspora and Beyond
}

\author{
MARIE GODIN AND GIORGIA DONÁ
}

\begin{abstract}
This article examines the role of new social media in the articulation and representation of the refugee and diasporic "voice." The article problematizes the individualist, de-politicized, de-contextualized, and aestheticized representation of refugee/diasporic voices. It argues that new social media enable refugees and diaspora members to exercise agency in managing the creation, production, and dissemination of their voices and to engage in hybrid (on- and offline) activism. These new territories for self-representation challenge our conventional understanding of refugee/diaspora voices. The article is based on research with young Congolese living in the diaspora, and it describes the Geno-cost project created by the Congolese Action Youth Platform (CAYP) and JJ Bola's spoken-word piece, "Refuge." The first shows agency in the creation of analytical and activist voices that promote counter-hegemonic narratives of violence in the eastern Democratic Republic of Congo, while the second is an example of aesthetic expressions performed online and offline that reveal agency through authorship and ownership of one's voice. The examples highlight the role that new social media play in challenging mainstream politics of representation of refugee/diaspora voices.
\end{abstract}

\section{Résumé}

Cet article étudie le rôle des nouveaux médias sociaux dans la politique de la représentation de la "voix» des réfugiés et de la diaspora. Il propose une problématisation des approches trop souvent dépoliticisées, uniformisées et individualisées à la représentation des "voix des réfugiés et de la diaspora». Il soutient que les nouveaux médias sociaux permettent aux réfugies d'exercer leur propre volonté d'agir en gérant la création, la production et la dissémination de récits alternatifs et en s'engageant dans un militantisme hybride (en ligne ainsi que hors ligne). Ces nouveaux lieux d'auto-représentation mettent en question nos conceptions conventionnelles des voix des réfugiés et de la diaspora. En se basant sur la recherche parmi de jeunes Congolais faisant partie de la diaspora au Royaume-Uni, l'article décrit le projet geno-cost développé par le Congolese Action Youth Platform (CAYP), ainsi que la création poétique orale intitulée "Refuge» de JJ Bola. Le premier exemple étudie l'exercice de la volonté d'agir qui se manifeste dans le développement de voix analytiques et militantes qui appuient des récits anti-hégémoniques concernant les causes et les solutions du conflit prolongé en République démocratique du Congo, alors que le deuxième exemple représente une instance d'expression politique et esthétique performée en ligne ainsi que hors ligne qui démontre la volonté d'agir par l'entremise de la création et la possession de sa propre voix. Effectivement, ces exemples soulignent le rôle que jouent les nouveaux médias sociaux pour contrer les politiques conventionnelles de représentation en matière de voix des réfugiés et de ceux qui font partie de la diaspora. 


\section{Introduction}

This article argues that the use of new social media challenges mainstream constructions of "refugee voices" in two ways: first, by challenging existing power relations among refugees/diaspora members and other social actors such as researchers, representatives of humanitarian agencies, and journalists; and second, by enabling refugee and diasporic groups to challenge the concept of "refugee voices" by re-politicizing, heterogenizing, and adding a collective dimension to the term. The accessibility of new social media promotes refugee agency in managing the creation, production, and dissemination of a multiplicity of "situated refugee voices"1 while challenging some of its misconceptions. In the first section of the article we problematize the concept of "refugee voices." The second section describes two projects that highlight new ways of representing activist "voices" within the Congolese diaspora youth. The last section discusses the ways in which projects that use new social media challenge the conventional politics of representation of "refugee voices."

\section{Problematizing "Refugee Voices"}

The introduction of the term refugee voices or voice into the discussion of migration and refugees was instrumental in making explicit the contribution of refugee diasporas to the production of knowledge and action. In the first issue of the Journal of Refugee Studies (JRS) (1988), the editor Roger Zetter wrote, "JRS will actively encourage publication of material in this genre, especially by refugees. We wish to give expression to their voices as much as to their existence as research data, and to their stories as much as their abstraction as cases."2 Following this statement, "Refugee Voice Section" appeared in the $J R S^{3}$ as well as in other dedicated edited collections on refugees. ${ }^{4}$ Under the umbrella term, refugees have come to occupy centre stage in relation to other social actors. Their stories, which might otherwise have remained unheard and been excluded from state/agency-centred representations, are made audible. Forced migrants become narrating subjects who challenge portrayals of refugees as passive, vulnerable, needy victims or threatening outsiders ${ }^{5}$ and whose accounts refer to personal, lived, and first-hand experiences of persecution, displacement, and exile. ${ }^{6}$

Subsequently, "refugee voices" have become more audible in the aesthetic/cultural production of exile, migration, and diasporic life.7 In order to avoid what is called the "expert testimony" mode 8 to represent the conditions under which refugees live, some organizations have opted to use testimonies, life stories, narratives, and other forms created by refugees themselves to advocate on their behalf. Yet, despite a will to listen, these voices still speak, as Rajaram ${ }^{9}$ says, within boundaries that are ideologically framed and rely on topdown analyses of need assessment for refugees. This approach reproduces discursive Western frames based on trauma and pathologization and gives credibility to humanitarian actors in speaking for refugees. ${ }^{10}$ In spite of the inclusive aims of the "refugee voices" project, there are limitations and contradictions in its application. These potential limitations, which are examined in the next section, are interrelated. Our research on new social media and the politics of representation of "refugee voices" allows us to explore three potential shortcomings in current uses: first, it is a form of de-politicization; second, it tends toward homogenized representation; and finally, as a process it is de-collectivized.

\section{"Refugee Voices" as "De-politicized Voices"}

There is a political dimension to the refugee experience whose significance can be lost in personal accounts framed by social actors such as academics and representatives of humanitarian organizations. Refugees' political lives often disappear into the background, and their "voices" tend to become apolitical. ${ }^{11}$ The term refugee voices becomes synonymous with the personal and human side of the story, marginalizing individual or collective self-representation. Abstracting displaced people from specific political, historical, and cultural milieus may ultimately lead to what Malkki calls the silencing of refugees. ${ }^{12}$ While refugees flee their country as political subjects, during their journey they appear to lose political agency to become, upon arrival in host countries, the objects of migration and asylum policies, the beneficiaries of assistance, or individuals with traumatic stories. This de-politicization regularly persists after they have settled in their host society.

\section{"Refugee Voices" as a Being Homogenized as "One Voice"} The term refugee voices can lead to a homogenized representation of the refugee experience. This is visible in the idea of the refugee journey or cycle or the emphasis on the human and psychological dimension. The personal experience is often represented through the idea of phases or cycles classically described in terms of pre-flight, flight, and post-flight (resettlement or return) ${ }^{13}$ or the refugee cycle. ${ }^{14}$ The phases are divided, and the links across them are being reimagined; the traumatic dimension of their experience is emphasized. In this process, different experiences are transformed into one universal refugee voice that summarizes the human/psychological trajectory from violence to safety. Refugees' narratives tend to convey similar experiences of loss, trauma, vulnerability, resilience, and ultimately some form of adaptation. ${ }^{15}$ The qualitative singularities of multiple "refugee/diasporic voices" become a homogenous narrative within which context and diversity become secondary, rarely appearing in humanitarian, academic, or media discourses.
(C) Author(s), 2016. This open-access work is licensed under a Creative Commons Attribution-NonCommercial 4.0 International license.
Cette oeuvre en libre accès fait l'object d'une licence Creative Commons Attribution-NonCommercial 4.0 International. 


\section{"Refugee Voices" and the Exclusion of the Collective}

\section{Dimension}

The de-politicization and individualization of voices leave less room for collective histories or situated belongings. Telling only the "human" side of the story can lead to collective disempowerment, by which the socio-cultural contexts are marginalized and the collective experience is made secondary. ${ }^{16}$ The experience of violence and persecution is a collective and situated one, yet through their journey the personal prevails over the collective and the situated positionality. The focus on individual experience forces the refugee to deny the collective dimension of persecution, leading to a form of unrootedness. Such normative discourses create empathy and a sense of a better understanding of the refugee/diasporic experience, but they also create a distance between a hypothetical "us" versus "them." The connection between the two is often annihilated, and that leads to an absence of critical reflection by the international humanitarian regime, ${ }^{17}$ and to a denial of the global ethical responsibility concerning the root causes of migration.

In this article, based on our research with young Congolese in the United Kingdom, we use two examples of refugee/ diasporic voices that use social media and challenge de-politicized, homogenized, and individualistic representations while adding layers of complexity within this landscape of the politics of representation.

\section{New Mediated Political Territories for Self- Representation: Forced Migration, "Refugee Voices," and New Social Media}

As highlighted by Horst in her pioneering article on the value of electronic media for research amongst refugee diasporas, "Far from being 'virtual,' computer-mediated communication is yet another means of social contact between people at a distance from each other." ${ }^{18}$ Since then, a range of studies have provided a substantial analysis of information and communications technology (ICT) refugee literacy through which refugees can perform their agency despite restrictive asylum policies. These narratives ${ }^{19}$ are therefore in stark contrast with prevailing clichés of refugees as needy, vulnerable, passive, and victims. Doná makes the point that in protracted refugee situations, forced migrants living in prolonged displacement create a virtual form of homemaking, linking past with future "Homes."2o

Other studies reflect on how social media can be a way for refugees to distance themselves from the refugee label and its negative connotations. In this respect, Witteborn shows how "technologically mediated sociality"21 can either enable refugees to become invisible (as deficient categories) and assert themselves in the virtual as well as embodied realm through co-presence and self-representation, or can also be used to become visible as a political force..$^{22}$ The "refugee" label is then redefined by refugees and becomes a discursive force for political mobilization both online and offline. In contrast to the idea of "being a refugee" (a more static and essentialist approach), Witteborn introduces a more dynamic approach through the concept of becoming: "a process through which people shift between different moments and ways of being and relating while responding to historical, sociopolitical and economic realities, and moving towards new ways of experiencing and acting in the world." 23

New ICTs promote the articulation of diasporic and refugee voices in transnational and trans-generational spaces that enable the creation of narratives that are both lived and alive, and promote hybrid activism in virtual and nonvirtual spaces. ${ }^{24}$ The Internet brings people into contact in a public agora, to voice their concerns and share their hopes. As Bernal argues, "People's control of this public agora is perhaps the most fundamental political issue raised by the development of the internet."25 Many authors have argued that second-generation migrants are less likely to engage with their country of origin with the same intensity and frequency as their parents. ${ }^{26}$ But as Levitt points out there are no clear-cut divisions between the home country and the host country, between the first and the second generation, all of which are integrated within an interconnected social experience. ${ }^{27}$ There is a growing literature on the political activism of the $1.5 /$ second generation that describes new ways of engaging with the politics of representation. ${ }^{28}$ The examples below show that a plurality of identities can become visible through the use of social media establishing connections beyond the too-often ascribed identity categories either as refugees or diaspora actors.

\section{Methodology}

This article draws evidence from our ethnographic research with young Congolese in the United Kingdom. First, we examine the Geno-cost project ${ }^{29}$ undertaken by the Congolese Action Youth Platform (CAYP) ${ }^{30}$ to denounce the ongoing narrative of denial of the genocide in eastern Democratic Republic of Congo (DRC). Geno-cost is a project that is present both online (Twitter, Facebook, and a blog) and offline. Ethnographic work was undertaken between October 2012 and August 2015 with CAYPV's active members. One of the co-authors participated in CAYP's weekly Skype meetings where projects were discussed and connections with young Congolese living both in DRC (city of Goma, eastern DRC) and Europe (e.g., Belgium) were maintained. Additionally, physical meetings took place regularly in London. Relying on Boellstorff's definition of digital anthropology as a technique to study "the relation between the
(C) Author(s), 2016. This open-access work is licensed under a Creative Commons Attribution-NonCommercial 4.0 International license.
Cette oeuvre en libre accès fait l'object d'une licence Creative Commons Attribution-NonCommercial 4.0 International. 
virtual (the online) and the actual (the physical or offline)," we explored this project both in its virtual manifestations and in its relations to the actual. ${ }^{31}$ Second, we examine the spoken word piece "Refuge" by JJ Bola, a young British Congolese born in Kinshasa and raised in London. Bola is a writer, poet, spoken word artist, social commentator, speaker, and educator. "Refuge" has appeared on social media platforms such as YouTube and Facebook, and in his blog. ${ }^{22}$ Two in-depth interviews with Bola were conducted in London between March and December 2014.

To help us reconsider the power relations between the researcher and the youth, we rely mainly on feminist methodology literature, which strives for more reciprocal relationships rethinking approaches to "subalternity, voice, authorship, and representation." 33 Young activists in the Congolese diaspora, whom one of the authors interviewed in the framework of her $\mathrm{PhD}$ dissertation, can be identified as activist-researchers, whereas she, being foremost a researcher, has become a research-activist within CAYP. Both researchers initiated (as much as possible) a transversal political dialogue. Via the interplay between acts of rooting and shifting-as defined in transversal politics ${ }^{34}$ - we have tried to place ourselves in a position to hear "multiple voices of knowledges" and discuss them. In essence, the research aims to be useful in working towards their goals of social justice and social change. Using feminist research practices, we have tried to achieve a process of "research with" or "for" rather than "on." 35 To avoid misrepresenting their voices, we have, as promoted by Bassel, been "shifting from speaking to listening." 36 While we are aware that we are still part of the "old system," our standpoint is different. With social media, there is scope for much greater open access, critical discussions, and more equal relationships allowing for conventional boundaries to be broken. The "subjects" have more resources to challenge researchers, who might misrepresent them, pushing them to be more accountable. The research therefore takes place within a broader environment of "political listening"37 allowing young people to challenge knowledge hierarchies as well as hierarchies of credibility.38

The virtual aesthetic narratives of the Geno-cost project and the "Refugee" poem show the will of second-generation Congolese in the United Kingdom to counter hegemonic narratives of the DRC conflict and its root causes and solutions while challenging the widespread image of the refugee as "bogus" through both virtual and non-virtual aesthetic representation, hybrid activism, and live narratives.

\section{A New Generation of Young Congolese Activists in the United Kingdom}

Young refugees and members of diasporas are part of mixed migratory flows in which forced and voluntary motives cannot be separated. Young people make transnational connections that are often based on their identification with their country or their families. The global increase in asylum seekers and refugees since the 1990s has made the criterion of dispersion (forced or otherwise) widely understood as constitutive of diaspora. ${ }^{39}$ However the usual concept of diaspora de-emphasizes the forced component of migration. Therefore, the terms refugee voices and diaspora voices can overlap, as they do in our case study. As discussed by Garbin and Godin, ${ }^{40}$ a Congolese diaspora first emerged in Europe during the 1960 s and early 1970s in Belgium, the former colonial power. The majority were students and senior civil servants and elites of the Mobutu regime who were then migrating temporarily basis. In the aftermath of independence, many settled in Belgium as the result of the political and economic turmoil in the Congo. In the late 1980 s and especially in the early 1990s, with the deterioration of socio-economic conditions in the Congo and more restrictive asylum and migration policies in France and Belgium, new destinations emerged such as South Africa, Nigeria, France, Canada, and the United Kingdom. In the United Kingdom, the Congolese represent the biggest group among the new francophone African diasporas. ${ }^{41}$

The collective mobilization of young Congolese in London can be traced to the autumn and winter of 2011-12 when a tense electoral campaign in the home country led to the contested re-election of Joseph Kabila as president of the DRC..$^{22}$ For many Congolese youths in the United Kingdom, the 2011 presidential and parliamentary elections in the DRC ( 28 November) were the triggers that motivated them to raise their own voices. Because there was no representational space for their concerns and political analyses in the diaspora and in mainstream institutions in the host society, young Congolese activists in the United Kingdom enacted a significant shift in representing their political concerns. As one young Congolese activist from CAYP explained during an interview, "We were outraged at the fact that we were protesting for three months in central London, Oxford Circus, in Regent Street and even outside the door of the British Broadcasting Corporation, the $\mathrm{BBC}$, and yet there was almost no coverage in the mainstream news. And the couple of articles were focusing ... on misrepresenting or demonizing the protests by telling that they were causing a lot of disruptions to the public order, rather than stating the outcry that was going on." 43

This account explains why young Congolese have used social media as the main transmitters of their political voice. As CAYP's spokesperson pointed out during a public meeting, they decided to "replace the BвC." 44 Their agency is exercised in the new social media, which are more effective tools for conveying their concerns, raising awareness, and expressing
(C) Author(s), 2016. This open-access work is licensed under a Creative Commons Attribution-NonCommercial 4.0 International license.
Cette oeuvre en libre accès fait l'object d'une licence Creative Commons Attribution-NonCommercial 4.0 International. 
their voices. As there was no representational space for their concerns and political analysis in mainstream institutions of the host society, and within the diasporic political mediaspace dominated by more radical activists such as Les Combattants (The fighters), who are mainly male activists of the first generation, ${ }^{45}$ young Congolese in the United Kingdom have decided to take greater ownership of their voice, the spaces in which it is represented, and the modes of representation. ${ }^{46}$ One of their campaigns is the Geno-cost project, which suggests alternatives and counter-narratives through both virtual and non-virtual forms of political representations that promote young people's agency.

\section{The Geno-cost Project}

The Geno-cost project is the result of young Congolese people's research, revisiting dominant historic representations of the conflict in eastern DRC, and generating their own counter-hegemonic historic narrative of events. The word Geno-cost combines the term geno for genocide and cost. The term genocide highlights the systematic killing of the population of the DRC and refers to the official definition of the term adopted by the United Nations General Assembly. 47 To mark the specificity of several genocides that took place in the DRC, CAYP wanted to establish a direct link between the killing of people and the plundering of natural resources. The central platform of the project is an event that represents a commemoration and remembrance of all the genocides in the DRC during and since colonialism, but also the one that is still happening. The "cost" of the Geno-cost project highlights the economic roots of the conflicts, as CAYP's spokesperson explained: "Congolese people are not dying because they are Congolese, but because of a predator industry that only cares about money, not people." 48 This statement expresses a collective political voice that in the mainstream conceptualization of refugee/diasporic voices is often marginalized or missing. Instead of privileging the formation of individual agentic voices, young Congolese in the diaspora are producing new forms of collective and intersubjective agentic voices through social media. The Geno-cost project is a commemorative day that has taken place every 2 August since 2013. As one active member of the platform explained during one of these events,

When we started doing our research, we realized that no one spoke of the dead in Congo, the six million people who have died in the heart of Africa, the deadliest conflict since World War II, and it does not make the headlines like Syria, like Afghanistan and Libya ... and this conflict has lasted for more than twenty years. So we decided that we had to do something ... What was sad is when we did our research, we came across a date that we, the Congolese, did not know about; it is the date of 2 August 1998, the second war of aggression in the Congo 49 ... This is a date we do not know about as a community, and if we, the Congolese people, don't start to commemorate this date, it is a date that will be erased..$^{\circ}$

CAYP's initiative is directed towards the Congolese community and therefore aims at internal rather than external awareness. It is defined by CAYP's activists as a political duty enacted against a habit (especially of the elders) that has been characterized for too long by an attitude of dependency by the Congolese people on the West and a reliance on others to define them.

As highlighted by Bernal, the use of new social media allows diasporic communities to transform the ways in which the national politics of representation of individual and group histories are conducted and understood. $5^{11}$ One aim of the Geno-cost annual event is for young Congolese activists to promote "counter-hegemonic positive voices." To do so, CAYP members bring in not only their own perspectives, but those of young people still living in the DRC. For instance, during the second Memorial Day in 2014, a short documentary was screened: Resilience: Tales from Goma, ${ }^{2}$ produced with the support of CAYP members in Goma. Using a weekly Skype meeting, members based in Goma, London, and Brussels developed the synopsis of the documentary, which shows another side of the conflict-torn Congolese city of Goma. It portrays the work and hopes of the unsung heroes who overcame multiple challenges and obstacles to bring change and hope to the Congolese people. Resilience is the main message, defined in the documentary as "the power or ability to return to the original form, position, etc., after being bent, compressed, or stretched; elasticity-the ability to recover readily from illness, depression, adversity, or the like; buoyancy." Therefore, the project aims to amplify the voices of local people who are willing to make a change.

Resilience has been used to show that in Congolese diaspora politics the ways of being "political" and relating to the homeland are different from those of first-generation activists. First-generation political activism (as incarnated by Les Combattants) is often based on challenging those in power back home. This is done mainly through marches and petitions and can therefore be characterized as dominant diaspora politics. Showing real life for activists is also a way for young people in the diaspora to relate to political matters locally. In the literature, the 1.5 generation is often seen as a bridge between the first generation (their parents) and the host society. Here the 1.5 generation is acting as a bridge between the second generation (those who were either born in the United Kingdom or who came at an early age) who have lost contact with their "homeland" and the young
(C) Author(s), 2016. This open-access work is licensed under a Creative Commons Attribution-NonCommercial 4.0 International license.
Cette oeuvre en libre accès fait l'object d'une licence Creative Commons Attribution-NonCommercial 4.0 International. 
generation back home. Through social media, a physical reconnection between the youth in the United Kingdom and Europe and the youth in the DRC can bring positive change based in local realities. In doing so, these new ways of politically representing their home country can challenge representations of the DRC, which is often portrayed in mainstream media as the "rape capital of the world" 53 or "the worst place on earth to be a woman." 54

Through the Geno-cost virtual campaign, Congolese groups and individuals around the world can support and get involved in the commemoration, online and offline. Having developed graphics for Geno-cost commemoration day, CAYP has adopted a copyleft55 strategy to get Congolese communities around the world-online and offline, in the diaspora and back home-to endorse their political project and organize their own commemorations. For instance, during the event in 2015, on several Facebook profiles, messages called for people to share via Facebook or Twitter a virtual candle as a mourning sign. As illustrated through the Twitter account of the Geno-cost project on 2 August 2015, the purpose was to remember those who died with either a real or a virtual candle that represented seventeen years of resistance, seventeen years of bravery, and seventeen years that the Congolese people will not forget (\#genocost, \#Congo).

In this way young Congolese participate in politics online by creating new territories in which the local, national, transnational, diasporic, and virtual intersect and overlap. Going online helps them gain confidence in expressing their voices and take authorship of their own research. By involving Congolese experts (academics, activists, community leaders) during the commemorative event and by emphasizing their message to a wider community online before, during, and after, they reclaim the value of the expertise of their own community, reframing the position of who is authorized to speak for whom. As one member of CAYP told the audience during the first commemoration day, "Today, it is true that Congolese people are not being told what is actually going on in Congo. Now it is time for us to actually say what we believe is going on in Congo. We are no longer in the nineteenth century. We have academics, we have historians, we have doctors and citizens, and we call ourselves 'independent.' So if we are independent we must be able to say what our history is." 56

One striking moment in the commemoration event takes place at the end, when six candles are lit one by one by members of the Congolese community (from young people to community leaders, including both men and women, representing a large spectrum of political voices within the diasporic political field). These six candles represent six prayers: to celebrate the memory of all the people Congo has lost to conflicts; for all six million lost in the ongoing conflict; for all child orphans who have lost their homes; for all victims of sexual violence; for all who have been displaced from their land; and finally, for the resistance of the Congolese people and hope for a better future. ${ }^{57}$ In doing so, the dynamics of the politics of representation are changed. Young Congolese activists in the United Kingdom and back home are working together via social media and include in their advocacy work a plurality of voices here (in the diasporic political field) but also there (back home).

One last tweet about the 2015 commemoration specifically targeted the audience online, making Geno-cost a global virtual event: "Also, to all those who shared the candle of hope in solidarity with the people of \#Congo \#DRC, thank you for making \#genocost global." 58

Young Congolese people in the diaspora recognize that it should be the state's responsibility to remember and commemorate past and ongoing violence in the DRC, and they are critical of its failure to do so. As a young Congolese activist from CAYP stated during a discussion, "Genocost will help us even pass laws back home to safeguard lives."59 The Geno-cost project aims to become a virtual war memorial of grassroots heroes. Through the use of the Internet and new social media, this young generation is creating symbolic resources to gain political support, first within the community and then in global civil society. They are writing a new national and collective history. In contrast to Rwanda, where the state, as argued by Turner, ${ }^{60}$ has been "staging" its diaspora to create a new Rwanda of national unity and reconciliation-an approach that can be characterized as "politics from above"-the Geno-cost project represents an instance of "politics from below" in which CAYP members exercise their agency and write and disseminate their own version of national history that could eventually be brought back home and re-territorialized. "Voices from above" (which include the ones from the international community, governmental representatives here and back home, Western media, etc.) are challenged through the creation, production, and dissemination of "voices from below." By using the Internet (but not only) to mark 2 August as a Congolese Genocide Remembrance Day, new forms of exilic and diasporic voices emerge that, as Bernal states, challenge conventional relationships between the state and its citizens. ${ }^{61}$ In this way, the hierarchical order is being contested between official and unofficial representations, public and private, and authorized and unauthorized voices in the refugee diaspora, back home but also beyond.

\section{The Spoken Word Poem "Refuge" by JJ Bola}

At the age of six JJ Bola arrived in London from the DRC (then Zaïre) with his family in 1992 as a refugee. As he said
(C) Author(s), 2016. This open-access work is licensed under a Creative Commons Attribution-NonCommercial 4.0 International license.
Cette oeuvre en libre accès fait l'object d'une licence Creative Commons Attribution-NonCommercial 4.0 International. 
in an interview, ${ }^{62}$ he and his family experienced refugee status for almost fifteen years, obtaining British citizenship in 2007. In forced migration studies, the refugee voice of somebody like JJ Bola is usually represented through firsthand personal accounts, meaning-making, and adaptation. While some of these elements are present in JJ Bola's poem "Refuge," the direct articulation of his voice shows greater complexity, dynamism, connections, and nuances, thus challenging conventional representations of a de-politicized, homogenized, and individualized refugee voice.

"Refuge" was first performed on February 9 2014, for the burgeoning spoken word and poetry platform called Word on the Curb, ${ }^{63}$ a new social media channel using spoken word and poetry to keep people in touch with news and current affairs. It is important to note that even if spoken word poetry can be read, to get the full meaning of this piece of art the author needs to perform it. The full experience requires a multi-sensory reception of the work. This spoken work performance has since been posted on social media such as Facebook and Twitter by JJ Bola himself and shared by many of his friends and followers. The use of social media challenges the frame through which refugee voices are often represented and disseminated by intermediaries like academics and non-governmental and activist organizations.

JJ Bola's poetry is a form of literary activism promoting refugee voices and rights. As he explained to us, when he recites his poems, stereotypes and stigma against refugees are more easily dissipated as people start to listen to real voices. JJ Bola has also chosen to use social media as a "virtual speakers' corner" 64 to positively influence the current refugee debate. As he mentioned, it is often easier to raise awareness online than doing it in real life, because new connections are being suggested (via powerful algorithms on whom to follow) with people who are potentially interested in the topic and who are willing to learn more about it. His message can then be spread a priori through more empathic social media such as in using specific hashtags (\#refugee, \#refugeevoice, and \#refugeeswelcome), allowing people who might not be in his circles of social relationships to learn more about his political voice.

For JJ Bola, the significance of his refugee identity emerged over time, shaped by what happened in the country of origin but also by the uncertain legal position of his family trapped in the asylum system. ${ }^{65}$ On the YouTube video, JJ Bola performs his poem on the Millennium Bridge in London, a place that stands as a metaphor for the connection between London and home (DRC), the bridge as a metaphor that stresses the continuity between "monsters" here and there, showing that the experience of being uprooted does not stop with the fleeing.
My father would speak of home. Reaching. Speaking of familiar faces. Girl next door who would eventually grow up to be my mother. The fruit seller at the market. The lonely man at the top of the road who nobody spoke to. And our house at the bottom of the street lit up by a single flickering lamp where beyond was only darkness. There we would sit and tell stories of monsters that lurked and came only at night to catch the children who sat and listened to stories of monsters that lurked. This is how they lived ... We came here to find refuge. They called us refugees so we hid ourselves in their language until we sounded just like them. Changed the way we dressed to look just like them. Made this our home until we lived just like them and began to speak of familiar faces. girl next door who would grow up to be a mother. The fruit seller at the market. The lonely man at the top of the road who nobody spoke to ... There we would sit and watch police that lurked and came only at night to arrest the youths who sat and watched police that lurked and came only at night. This is how we lived. ${ }^{66}$

The poem reflects JJ Bola's refugee experience and aims to situate the refugee ordeal in context (from the country of origin to the destination country), but it goes beyond his individual trajectory. As he tweeted in March 2015, "Being a refugee transcends class, race, gender, religion, faith, education etc. the experience stems from a trauma few know." This statement echoes what he explained to us in an interview: "What I think is unique about the refugee experience is that it challenges race, class, or even gender ... like among my peers, Afro-Caribbeans or black, I would still kind of [have the] feeling that I was being 'the refugee' and there were other friends ... who were not necessarily the same ethnic group but they could understand me because of their refugee background ... it is going beyond your own community, beyond the language of borders, it is your experience, little things." 67

However, here JJ Bola is also challenging essentialist representations of refugee identity. His aim is not to reify the refugee experience, ${ }^{68}$ which, as pointed out by Mal$\mathrm{kki}$, tends "to fix and make permanent something 'essential' about these processes and to do so by personalizing them." 69 Through his poem, JJ Bola wants to point out that the experience of "becoming a refugee" is transcendent and goes beyond race, class, gender, religion, and any other fact; we could all be effected by it. His approach to the experience of becoming a refugee is "not to fix or make it permanent rather, it's to take a moment, and add it to the many moments that have existed previously and how the refugee experience is tied in to all of the experience of humanity." 70 In line with Witterborn's concept of becoming introduced, through which people shift between different moments, in December 2014 he tweeted, "I'm a Congolese, African,
(C) Author(s), 2016. This open-access work is licensed under a Creative Commons Attribution-NonCommercial 4.0 International license.
Cette oeuvre en libre accès fait l'object d'une licence Creative Commons Attribution-NonCommercial 4.0 International. 
refugee migrant, working-class boy from inner city London." Proud of his multiple social heritages, he is juggling multiple, sometimes conflicting, social identities that are paramount when looking at his poetry and political voice.

Similarly, besides his literary refugee activism, JJ Bola is concomitantly engaged in diaspora activism. As a member of CAYP, he performs his poetry at events such as the Genocost commemoration discussed earlier. On August 2, 2015, he performed the poem "tell them (they have names)":

And when they turn the bodies over

to count the number of closed eyes. And they tell you 800,000:

you say no. That was my uncle. He wore bright coloured shirts and pointy shoes.

2 million: you say no. That was my aunty.

her laughter could sweep you up like

the wind to leaves on the ground.

6 million: you say no. That was my mother. ${ }^{71}$

As he tweeted the day of the event, "It should not take violent images and guilt for us to feel each other's humanity. Not for Congo, not for West Papua, Syria etc. Our human ity should not have to be evoked or provoked for us to feel another's suffering. We have been desensitized, particularly to dead black bodies; African bodies."72 This statement shows that his political engagement often goes beyond the strictly Congolese diasporic political sphere and operates across several scales, from local to global. Through his poetics of advocacy, JJ Bola is trying to raise global social awareness of global injustices and of the role that every one of us can play in not staying silent. In doing so, he is transcending traditional identity boundaries as well as voices. This capacity for juggling with a plurality of political voices and the possibility of making connections is being facilitated through social media. On 4 September 2015, JJ Bola tweeted an image of his full poem "tell them (they have names)," adding, "This is for Aylan Kurdi, who we know and for those whose names we do not know." In doing so, he shows transversality of political identities and political voices and invites everyone to do the same, encompassing difference by equality. ${ }^{73}$

On the video in which he performs the poem "Refuge," a crowd of people cross the bridge without noticing him. With this visual setting, JJ Bola wants to normalize the refugee experience that could happen to anyone, regardless of place of origin, age, sex, religion, or political opinion. $\mathrm{He}$ wants to get away from stereotypical representations of the refugee experience and to show that it is a global issue, not a personal choice. Through this spoken word piece, he aims to reverse the "humanity" of the "refugee voice" because he does not want to display sympathy or pity for the "victim" but rather solidarity based on equality, on the grounds that anybody could become a refugee, because political contexts can change anywhere: "Being a refugee is not something that you choose to become and is not based on merit or talent. It is the result of unfortunate circumstances that can affect anyone, anywhere."74 In doing so, he goes against victimization as the main meaning of the refugee experience and avoids the risk of internalizing the political representation of victimhood. He also wants to point out the need for the wider responsibility-sharing of refugee flows, not only on behalf of states but also of every individual who should always remember that he or she could become a refugee. The message of this spoken word piece is being amplified through sites like YouTube and other social media platforms, and aims to help the audience understand the connections and simultaneity of the global and the local, the personal and the collective. In the last stanza of his poem, JJ Bola brings humanity to the fore, reminding everyone that we are all potentially refugees in search of a place that can be called "home." On that basis, solidarity should prevail when dealing with refugees: "I told them that a refugee is simply someone who is trying to make a home, so next time, before you go to sleep and kiss your families goodnight, be glad that the monsters never came for you, in their suits and ties, never came for you, in the newspapers, with the media lies, never came for you, and that you are not despised. Because deep inside the hearts of each and every one of us, we are all always reaching for a place, that we can call home."75

\section{Discussion}

This article has examined the role that new social media play in the politics of representation of "refugee voices." Throughout, the opportunities of digital media and the features of different platforms such as Twitter and Facebook have been discussed, highlighting changes that new social media are making in amplifying refugee voices.

Both case studies-the CAYP Geno-cost project and the spoken word piece "Refuge" by JJ Bola - illustrate the ways in which the refugee/diaspora experience is being "re-politicized" by social media. In the Geno-cost project, young Congolese are engaged in researching, analyzing, rewriting, and retelling their country's history of violence and the conflict over natural resources and the economic costs. CAYP also wants to go beyond the individual suffering of people, such as the forced migrant. The focus is on the power relations that have led to the protracted conflict in the DRC, not on individual suffering and personal trajectories. Diasporic agents, and in particular young people, are rewriting a social national history celebrating local voices as national heroes from the grassroots level. Social media offer the space where these grassroots stories can be shared, diffused, and known. The Geno-cost event empowers the Congolese community,
(C) Author(s), 2016. This open-access work is licensed under a Creative Commons Attribution-NonCommercial 4.0 International license.
Cette oeuvre en libre accès fait l'object d'une licence Creative Commons Attribution-NonCommercial 4.0 International. 
but not the people back home, as often conceptualized in diaspora studies, through concepts such as "social remittances." 76 Rather, it shares the political voices of young Congolese people back home to empower young people in the diaspora (both young men and women), to change the negative image of their country of origin, to inform them about political problems in their country of origin, and eventually to convince them to be part of a change back home. The Geno-cost event empowers the Congolese community in re-writing history from the bottom up, by and for civilians in the diaspora and back home. By taking place both online and offline, the Geno-cost project suggests a new dialectic of mutual empowerment and collaboration based on a more equal relationship between those back home, in the diaspora and beyond. In the case of JJ Bola, his poem challenges mainstream anti-refugee discourse and puts the stress on the political experience in the home country (both at the individual and collective level), but he also re-politicizes the refugee experience in the host country by establishing connections with other marginalized groups. In so doing, he shows that refugee experiences take place within a political spectrum from the country of origin to the one of settlement. The Internet and its tools (Youtube, Twitter, and Facebook) allow information and political views to be shared directly and discussed among members in a more decentralized, unregulated, and egalitarian mode.

These two examples show the heterogenization of situated voices and experience. Young Congolese activists do not pretend to be The Voice, but they are adding their voices, highlighting a heterogeneous representation of what constitutes "refugee voices." Young activists use new social media to raise political awareness, promote diasporic social and political initiatives, and participate in youth cultures within the receiving societies. For young people, new information and communication technologies have become instrumental and symbolic tools that identify them as global citizens and members of global youth cultures. Through the Genocost project, young Congolese activists are re-politicizing their positions among other dominant discourses within and beyond the diaspora, not only as Congolese young people but as global citizens.

JJ Bola's poem shows how individuals are embedded in multiple social roles and identities that often overlap, intersect, and connect. Social media allow individual and collective social actors to go beyond universalistic politics (which are ethnocentric and exclusionary) as well as identity politics (which are essentialist). ${ }^{77} \mathrm{JJ}$ Bola's public statement at the Global Summit to End Sexual Violence in Conflict in $2014^{78}$ on DRC conflict minerals and ICTs illustrates quite well this rising possibility of engagement in transversal politics by youth who are using social media:
I am just going to echo what Dr. Mukwege ${ }^{79}$ said. He spoke about there being a grassroots movement. He spoke about there being change from the bottom up ... Each and every one of us is directly affected by it [Congo's conflict minerals and the use of the mobile phone], and it is about changing the narrative and not just relying on the government or the media to dictate whatever people are thinking, but also for us to be able to speak about our experiences, to come here and have this platform where we don't just educate, but also enlighten people about what's going on back home so that each and every one of us can feel connected to the conflict back home, and connected in a sense that, we feel empowered to be able to change something ... I think it is about us, this generation, in this technological era, for us to use that, that platform that we have, to be able to spread the narrative. ${ }^{80}$

Finally, in both projects, the re-collectivization of voices takes the form of a shared collective responsibility. In the Geno-cost project, the root causes are being addressed, and everyone's responsibility and capacity for change is highlighted. JJ Bola shows that there is a shared responsibility for addressing the root causes of any refugee situation. Through his poem, he distances himself from the ordinary process of refugee homogenization as victims only, and stresses the potential universal experience of becoming a refugee. In highlighting the fact that anyone could become a refugee, he wants to stress our shared humanity as a principle that should make us feel connected to any refugee around the world. Going online makes their perspectives visible by multiple audiences, both Congolese and non-Congolese, simultaneously.

This article contributes to ongoing discussions on "Refugee Voices" by giving a voice to a social group that is often unheard in diaspora and refugee studies: the youth. It explores the nature and character of the "situated voices" of young Congolese in the diaspora and their increasing use of ICT. Social media are not free from the tangled webs of inequitable power relations across the globe. But in creating their own channels, young Congolese are challenging global power relationships as well as diasporic power relationships at the local, national, transnational, and international levels. And in their engagement, they are also challenging the mainstream politics of the representation of refugee voices.

Marie Godin is a research officer at the International Migration Institute at the University of Oxford. The author may be contacted atmarie.godin@qeh.ox.ac.uk.

Giorgia Doná is professor of refugee studies at the School of Social Sciences, University of East London. The author may becontactedatg.dona@uel.ac.uk.
(C) Author(s), 2016. This open-access work is licensed under a Creative Commons Attribution-NonCommercial 4.0 International license.
Cette oeuvre en libre accès fait l'object d'une licence Creative Commons Attribution-NonCommercial 4.0 International. 


\section{Notes}

Our warmest thanks to CAYP's active members and JJ Bola for their help at different stages of the project, as well as to Professor Dawn Chatty (Refugee Studies Centre), Refuge editors and anonymous referees for their useful comments.

1 Directly inspired by the concept of "situated knowledge" coined by Donna Haraway in "Situated Knowledges: The Science Question in Feminism and the Privilege of Partial Perspective," Feminist Studies 14, no. 3 (1988): 575-99.

2 Roger Zetter, "Refugees and Refugee Studies: a Label and an Agenda: Editorial Introduction," Journal of Refugee Studies 1 (1988): 1-6.

3 For example, Ron Baker, "Refugee Experience: Communication and Stress, Recollections of a Refugee Survivor," Journal of Refugee Studies 3, no. 1 (1990): 64-71; Mia FloresBorquez, "Refugee Voices: A Journey to Regain My Identity," Journal of Refugee Studies 8, no. 1 (1995): 95-108; Martha Kumsa Kuwee, “'No! I'm not a refugee!' The Poetics of Belonging among Young Oromos in Toronto," Journal of Refugee Studies 19, no. 2 (2006): 230-55.

4 Jennifer Langer, Crossing the Border (Nottingham: Five Leaves, 2002); Julie A. Mertus, Jasmina Tesanovic, Habiba Metikos, and Rada Boric, The Suitcase: Refugee Voices from Bosnia and Croatia (Oakland: University of California Press, 1997).

5 For example, Anette Day, “They listened to my voice’: The Refugee Communities History Project and BelongingVoices of London's Refugees," Oral History 37, no. 1 (2009): 95-106.

6 See Marita Eastmond, "Stories as Lived Experience: Narratives in Forced Migration Research," Journal of Refugee Studies 20, no. 2 (2007): 248-64; Peter E. Hopkins and Malcolm Hill, "Pre-Flight Experiences and Migration Stories: The Accounts of Unaccompanied Asylum-Seeking Children," Children's Geographies 6, no. 3 (2008): 257-68; Edward W. Said, Reflections on Exile and Other Literary and Cultural Essays (Cambridge: Granta Books, 2001).

7 Zuzanna Olszewska, "A Desolate Voice: Poetry and Identity among Young Afghans in Iran," Iranian Studies 40, no. 2 (2007): 203-24.

8 Liisa H. Malkki, "Speechless Emissaries: Refugees, Humanitarianism, and Dehistoricization," Cultural Anthropology 11, no. 3 (1996): 377-404.

9 Prem Kumar Rajaram, "Humanitarianism and Representations of the Refugee," Journal of Refugee Studies 15, no. 3 (2002): 247-64.

10 Nando Sigona, "The Politics of Refugee Voices: Representations, Narratives, and Memories," in The Oxford Handbook of Refugee and Forced Migration Studies, ed. Elena Fiddian-Qasmiyeh, Gil Loescher, Katy Long, and Nando Sigona, 369-82 (Oxford: Oxford University Press, 2014).

11 Navine Murshid, The Politics of Refugees in South Asia: Identity, Resistance, Manipulation (London: Routledge, 2013).

12 Malkki, "Speechless Emissaries."
13 Egon F. Kunz, "The Refugee in Flight: Kinetic Models and Forms of Displacement," International Migration Review 7 , no. 2 (1973): 125-46.

14 Richard Black and Koser Khalid, eds., The End of the Refugee Cycle? Refugee Repatriation and Reconstruction, vol. 4 (New York: Berghahn Books, 1999).

15 Alastair Ager, ed., Refugees: Perspectives on the Experience of Forced Migration (London: Continuum, 1999); Giorgia Doná, "Psychology and the Refugee Experience," in Psychology Serving Humanity: Applications, ed. Saths Cooper and Kopano Ratele, 2:144-68 (London: Psychology Press, Taylor and Francis Group, 2014).

16 Derek Summerfield, "A Critique of Seven Assumptions behind Psychological Trauma Programmes in WarAffected Areas," Social Science \& Medicine 48, no. 10 (1999): 1449-62; Gillian McFadyen, "The Contemporary Refugee: Persecution, Semantics and Universality," in "The 1951 un Refugee Convention: 6o Years On," special issue of $e$-Sharp (2012): 9-35, http://www.gla.ac.uk/media/ media_234569_en.pdf.

17 Sigona, "Politics of Refugee Voices."

18 Cindy Horst, "In 'Virtual Dialogue' with the Somali Community: The Value of Electronic Media for Research amongst Refugee Diasporas," Refugee 23, no.1 (2006): 53.

19 See Linda Leung, "Taking Refuge in Technology: Communications Practices in Refugee Camps and Immigration Detention," New Issues in Refugee Research, Research Paper no. 202 (Geneva: The UN Refugee Agency, Policy Development and Evaluation Service, 2011); Geff Green and Eleanor Lockley, "Communication Practices of the Karen in Sheffield: Seeking to Navigate Their Three Zones of Displacement," Asian Journal of Communication 22, no. 6 (2012): 566-83.

20 Giorgia Doná, "Making Homes in Limbo: Embodied Virtual 'Homes' in Prolonged Conditions of Displacement," Refuge 31, no. 1 (2015): 67-73.

21 "Technologically mediated sociality" refers to the way social relations are being reshaped by technology in the form of Skype calls or Facebook, for instance. See Michele Willson, "Being-Together: Thinking Through Technologically Mediated Sociality and Community," Communication and Critical/Cultural Studies 9, no. 3 (2012): 279-297, and cited by Saskia Witteborn, "Becoming (Im)Perceptible: Forced Migrants and Virtual Practice," Journal of Refugee Studies 28 (2015): 351.

22 Ibid., 352.

23 Ibid., 364 .

24 For example, Angel Adams Parham, "Diaspora, Community and Communication: Internet Use in Transnational Haiti," Global Networks 4, no. 2 (2004): 199-217.

25 Victoria Bernal, "Civil Society and Cyberspace: Reflections on Dehai, Asmarino, and Awate," Africa Today 6o, no. 2 (2013): 20-36.

26 Alba Richard and Nee Victor, Remaking the American Mainstream: Assimilation and Contemporary Immigration
(C) Author(s), 2016. This open-access work is licensed under a Creative Commons Attribution-NonCommercial 4.0 International license.
Cette oeuvre en libre accès fait l'object d'une licence Creative Commons Attribution-NonCommercial 4.0 International. 
(Cambridge, mA: Harvard University Press, 2003); P. Kasinitz, J.H. Mollenkopf, and M.C. Waters, Becoming New Yorkers: Ethnographies of the New Second Generation (New York: Russel Sage, 2004).

27 Peggy Levitt, "Routes and Roots: Understanding the Lives of the Second Generation Transnationally," Journal of Ethnic and Migration Studies 35, no. 7 (2009): 1225-42.

28 Monika Hess and Benedikt Korf, "Tamil Diaspora and the Political Spaces of Second-Generation Activism in Switzerland," Global Networks 14, no. 4 (2014): 419-37; Koen Leurs, Digital Passages: Migrant Youth 2.o (Amsterdam: Amsterdam University Press, 2015).

29 More information on the project can be found on "Genocost," Facebook, https://www.facebook.com/GenoCost; on the official website, http://www.genocost.org/; or "Geno-cost," Twitter, https://twitter.com/Genocost.

30 For more information, see Congolese Action Youth Platform blog, www.congoayuk.wordpress.com.

31 Tom Boellstorff, "Rethinking Digital Anthropology," in digital anthropology, ed. Heather A. Horst and Daniel Miller, 39-6o (Oxford: Berg Publishers, 2012).

32 See "JJ Bola," Facebook, https://www.facebook.com/ jj.bola?fref=ts; http://www.jjbola.com; "JJ Bola," Twitter, https://twitter.com/JJ_Bola.

33 Amanda Lock Swarr and Richa Nagar, Critical Transnational Feminist Praxis, suny Series, Praxis: Theory in Action (New York: sunY Press, 2010).

34 Nira Yuval-Davis, "Human/Women's Rights and Feminist Transversal Politics," in Transnational Feminisms: Women's Global Activism and Human Rights, ed. M.M. Ferree and A. Tripp, 275-95 (New York: New York University Press, 2006).

35 Liz Stanley and Sue Wise, Breaking Out: Feminist Consciousness and Feminist Research (London: Routledge \& Kegan Paul, 1983).

36 Leah Bassel, "Speaking and Listening: The 2011 English Riots," Sociological Research Online 18, no. 4 (2013): 12, http://www.socresonline.org.uk/18/4/12.html.

37 Susan Bickford, The Dissonance of Democracy: Listening, Conflict and Citizenship (Ithaca, NY: Cornell University Press, 1996).

38 Bassel, "Speaking and Listening."

39 Rogers Brubaker, “The 'Diaspora' Diaspora," Ethnic and Racial Studies 28 (2005): 1-19.

40 David Garbin and Marie Godin, "'Saving the Congo': Transnational Social Fields and Politics of Home in the Congolese Diaspora," African and Black Diaspora: An International Journal 6, no. 2 (2013): 113-30.

41 Khalid Koser. "New African Diasporas: An Introduction," in New African Diasporas, ed. Khalid Koser, 1-16 (New York: Routledge, 2003).

42 Garbin and Godin, "'Saving the Congo,"” 113.

43 CAYP's Congolese spokesperson, Sylvestre Mido, interview in London, 2014.
44 Public meeting, CAYP's Congolese spokesperson, Sylvestre Mido, November 2013.

45 Ibid., 125.

46 Valeria Bello, "Virtual Belongings, Dual Identities and Cultural Discomforts: The Role of Mediaspaces and Technospaces in the Integration of Migrants," Crossings: Journal of Migration \& Culture 5, nos. 2-3 (2014): 213-29.

47 The Convention on the Prevention and Punishment of the Crime of Genocide was adopted by the United Nations General Assembly on 9 December 1948, as General Assembly Resolution 260. http://www.hrweb.org/legal/genocide .html.

48 CAYp's Congolese spokesperson, Sylvestre Mido, interview in London, 2014.

49 The DRC has experienced protracted conflict for almost twenty years. This first Congo War is often referred to as the "War of Liberation" (1996-8) by most Congolese and is marked by the end of Zaïre, that is, Kabila renaming the country the Democratic Republic of Congo. Shortly afterwards, in 1998, a second war erupted between Kabila and Rwanda and Uganda (and to a lesser extent Burundi), who were asked by the new president of the DRC to leave the country. The second Congo war took place between 1998 and 2003 and has been called a "war of aggression." The third war is still ongoing between armed groups and civilians, with women and children being the most affected by the conflict. For more information, see Gerad Prunier, Africa's World War: Congo, the Rwandan Genocide, and the Making of a Continental Catastrophe (Oxford: Oxford University Press, 2009); Jason Stearns, Dancing in the Glory of Monsters: The Collapse of the Congo and the Great War of Africa (New York: PublicAffairs, 2012).

50 Congolese activist from CAYP, Geno-cost, 2013, London.

51 Victoria Bernal, "Diaspora, Digital Media, and DeathCounts: Eritreans and the Politics of Memorialisation," African Studies 72, no. 2 (2013): 246-64.

52 Directed by Kelvin Batumike, who is also known for the video clip "Happy: We Are from Goma," based on Pharrell Williams's song "Happy," YouTube, https://www.youtube. $\mathrm{com} /$ watch? $\mathrm{v}=$ fq1uN2jbPIg.

53 ввC, "UN Official Calls DR Congo 'Rape Capital of the World,"” April 28, 2010, http://news.bbc.co.uk/1/hi/8650112 .stm.

54 Lisa Shannon, A Thousand Sisters: My Journey into the Worst Place on Earth to Be a Woman (Berkeley: Seal, 2010).

55 See Richard Stallman's GNU manifesto published in 1985. He invented the notion of "copyleft" and started shipping software with a licence that permitted redistribution and modification under the condition that any derived material be subject to the same licensing terms.

56 Geno-cost commemoration day in London, 2 August 2013. 57 Ibid., 2014, and 2015.

58 Geno-cost Twitter account, 2 August, 2015.

59 July 2013.
(C) Author(s), 2016. This open-access work is licensed under a Creative Commons Attribution-NonCommercial 4.0 International license.
Cette oeuvre en libre accès fait l'object d'une licence Creative Commons Attribution-NonCommercial 4.0 International. 
6o Simon Turner, "Staging the Rwandan Diaspora: The Politics of Performance," African Studies 72, no. 2 (2013): 265-84.

61 Victoria Bernal, "Diaspora, Digital Media, and Death Counts: Eritreans and the Politics of Memorialisation," African Studies 72, no. 2 (2013): 246-64.

62 Interview with JJ Bola in London, December 2014.

63 "Word on the Curb," YouTube, 2014, https://www.youtube. com/watch? $\mathrm{v}=$ ouWqV31QqLo.

64 This refers to Speakers' Corner, in Hyde Park, London, the most famous location for free speech in the world. It symbolizes popular struggles in Britain for the right to vote, speak, and assemble See "Speakers' Corner," http://www. speakerscorner.net/.

65 Marta Bausells and Maeve Shearlaw, "Poets Speak Out for Refugees: 'No one leaves home, unless home is the mouth of a shark,"' Guardian, 15 September 2016, http://www.theguardian.com/books/2015/sep/16/ poets-speak-out-for-refugees-.

66 "Refuge" has been published in his latest poetry collection, WORD, by writer/poet JJ Bola, which was released on 18 June 2015 during Refugee Week.

67 Interview with JJ Bola in London, December 2014.

68 Stephen L. Keller, Uprooting and Social Change: The Role of Refugees in Development (Delhi: Manohor, 1975).

69 Liisa H. Malkki, "Refugees and Exile: From 'Refugee Studies' to the National Order of Things," Annual Review of Anthropology 24 (1995): 495-523.

70 Facebook exchanges, 2016.

71 JJ Bola, "tell them (they have names)," Word (Amazon e-book, 2015). See JJ Bola's other books: Elevate (Amazon e-book, 2014); and Daughter of the Sun (Amazon e-book,
2014). All JJ Bola's books can be purchased on Amazon or via his blog: www.jjbola.com.

72 The text was also shared on his Twitter account on 2 August 2015: "Some thoughts on humanity and why I no longer share images of dead bodies to raise awareness \# genocost). (African Renaissance @JJ Bola-https://twitter. com/Genocost)

73 Nira Yuval-Davis, "What Is 'Transversal Politics'?” soundings 12 (summer 1999): 94-8.

74 Bola, interview, 2014.

75 Bola, "Refuge."

76 Peggy Levitt and Lamba-Nieves Deepak, "Social Remittances Revisited," Journal of Ethnic and Migration Studies 37, no. 1 (2011): 1-22.

77 Yuval-Davis, "What Is 'Transversal Politics'?," 94.

78 "Global Summit to End Sexual Violence in Conflict," GOV.UK, https://www.gov.uk/government/topical-events/ sexual-violence-in-conflict.

79 Dr. Mukwege is a Congolese gynaecologist who founded and works at Panzi Hospital in Bukavu (South Kivu province, DRC), where he specializes in the treatment of women who have been raped in the protracted conflict situation. See "L’Hôpital de Panzi," http://www.panzihospital.org/.

80 JJ Bola's public statement at the Global Summit to End Sexual Violence in Conflict held on 10 June 2014 at Excel London during CAYP's workshop on conflict minerals not to be understood as a Congolese issue but as a global issue. See "Not All Messages about Rape Were Welcome at Hague and Jolie's Sexual Violence Summit," Congolese Action Youth Platform Blog, 14 June 2014, https://congoayuk.wordpress.com/tag/ global-summit-to-end-sexual-violence-in-conflict/. 


\title{
How KANERE Free Press Resists Biopower
}

\author{
MICHELE C. DERAMO
}

\section{Abstract}

How does a free press resist state biopower? This article studies the development and dissemination of KANERE Free Press, a refugee-run news source operating in the Kakuma Refugee Camp, that was founded to create "a more open society in refugee camps and to develop a platform for fair public debate on refugee affairs" (KANERE Vision Statement). The analysis of KANERE and its impact on the political subjectivity of refugees living in Kakuma is framed by Foucault's theory of biopower, the state-sanctioned right to "make live or let die" in its management of human populations. The author demonstrates the force relations between KANERE, its host country of Kenya, and the UNHCR through two ongoing stories covered by KANERE: the broad rejection of the MixMe nutritional supplement and the expressed disdain for the camp's World Refugees Day celebration. Using ethnographic and decolonizing methodologies, the author privileges the voices and perspectives of the KANERE editors and the Kakuma residents they interviewed in order to provide a ground-level view of refugee's lived experiences in Kakuma. As KANERE records refugees' experiences of life in the camp, they construct a narrative community that is simultaneously produced by and resistant to the regulations and control of camp administration and state sovereignty. In doing so, KANERE creates a transgressive space that reaches beyond the confines of the camp.

\section{Résumé}

Par quels moyens peut une presse libre résister au biopouvoir de l'état? Cet article se penche sur le développement et la dissémination de la KANERE Free Press, une source d'actualités gérée par les réfugiés qui opère dans le Kakuma Refugee Camp (camp des réfugiés de Kakuma) fondé dans l'intention de créer "une société plus ouverte dans le camp des réfugiés et d'établir un cadre pour un débat public juste et équitable sur les questions concernant les réfugiés» (extrait de l'énoncé de vision KANERE). Cette analyse de la KANERE Free Press et de son impact sur la subjectivité politique des réfugiés installés à Kakuma s'opère dans le contexte de la théorie de Foucault du biopouvoir, le droit détenu par l'état de "faire vivre ou laisser mourir» dans son administration des populations humaines. L'auteur démontre les relations de force qui existent entre KANERE et son état hôte du Kenya, ainsi que le $\mathrm{HCR}$, par l'entremise de deux instances d'actualités en cours qui ont fait l'objet d'un reportage par KANERE: le rejet généralisé du complément alimentaire MixMe et le mépris manifesté à l'égard des fêtes du camp pour la Journée mondiale des réfugiés. En se servant des méthodologies ethnographiques et de décolonisation, l'auteur place au premier plan les voix et perspectives des rédacteurs de KANERE ainsi que les résidents qui ont participé aux entrevues afin de fournir un aperçu intime des expériences vécues des réfugiés à Kakuma. En rapportant les expériences de la vie des réfugiés internés dans le camp, KANERE développe une communauté liée par le récit qui est à la fois le produit des règlements et du système de contrôle de l'administration du camp et de la souveraineté de l'état, et un élément de résistance à cellesci. KANERE crée ainsi un espace transgressif dont la portée s'étend au-delà des limites du camp.

\section{Introduction}

A rticle 19 of the Universal Declaration of Human Rights affirms that all persons have the inherent right to freedom of opinion and expression. This right includes freedom to hold opinions without interference and to seek, receive, and impart information and
(C) Author(s), 2016. This open-access work is licensed under a Creative Commons Attribution-NonCommercial 4.0 International license.
Cette oeuvre en libre accès fait l'object d'une licence Creative Commons Attribution-NonCommercial 4.0 International. 
ideas through any media and regardless of frontiers. This article raises the question of how the exercise of free opinion and expression occurs for individuals living in conditions of liminality and subject to the regulations of state and international regimes. Specifically, this paper is about the Kakuma News Bulletin (hereafter KANERE), a free press founded and produced by exiled journalists living in the Kakuma Refugee Camp in Turkana County of the northwestern region of Kenya. KANERE's mission to "speak in respect of human rights and the rule of law in order to create a more open society in refugee camps and to develop a platform for fair public debate on refugee affairs" (KANERE Vision Statement) is fulfilled without editorial or financial intervention from the United Nations High Commissioner for Refugees (hereafter UNHCR), the government of Kenya, or any non-governmental organization (NGO) or aid agency associated with the camp. As a result of its decision to operate independent of external intervention, KANERE performs its mission from a position of precarity without a secure funding base and vulnerable to bureaucratic regulations that attempt to control the message being disseminated.

The analysis of KANERE and its impact on the political subjectivity of refugees living in Kakuma is framed by the theory of biopower, defined by Foucault as the state-sanctioned right to "make live or let die" in its management of human populations. ${ }^{1}$ Biopower describes the means by which modern nation-states regulate their subjects through "an explosion of numerous and diverse techniques for achieving the subjugations of bodies and the control of populations." I argue that the refugee camp functions as a technology of power that manages the feeding, housing, and provision of emergency services to populations whose fate as displaced persons is determined by the state. This is especially true in places such as Kenya, where current refugee policy requires that all refugees be contained in camps until a resolution to their status is determined. The effects of encampment is the subjugation of the very individuals it is meant to serve and protect. At Kakuma, residents are wholly dependent upon aid agencies for their survival. They exist in a state of liminality, displaced from their homelands as the result of protracted civil conflicts and segregated from local economies. The level of dependency among Kakuma residents is not only material, but psychic as well. According to Rose Jajj of the Centre for Social Development in Africa, whose research examines the administration of refugee camps, the "efficacy of the social technology in the administration of Kakuma ... manifests itself in refugees' internalization of bureaucratic rules as their own norms and values."3 Even the production and dissemination of information-whether it be opinion, personal expression, or fact-is subject to editorial oversight by camp administration. Within this context, KANERE'S function as a free press produces a transgressive public sphere that is coterminous with yet also resistant to the operations of biopower.

My approach and analysis are influenced by decolonizing methodologies that privilege the perspectives and lived experiences of the KANERE journalists and the Kakuma residents they interview. Drawing upon the work of Linda Tuhiwai Smith, decolonizing methodologies is defined here as the discursive production of knowledge by "insiders" about themselves for the purpose of dismantling oppression. ${ }^{4}$ Thus, at the centre of this investigation are the individuals who produce KANERE, whose commitment to conveying the experiences and opinions of refugees warehoused in one of the most dangerous camps in the world singles them out as troublemakers, placing their lives and their future prospects at even greater risk. Foremost among the KANERE journalists is its founding editor, Qaabata Boru, whose narrative of displacement and insider perspective as a resident of Kakuma is foundational to understanding KANERE's objectives as well as the challenges KANERE confronts in order to fulfill its mission. Boru is, first and foremost, a journalist, therefore his writing and editing are based on the standards of journalism acquired through academic training and professional experience. However, his approach is also influenced by his experience of exile and displacement that occurred as a result of his work as a journalist in Ethiopia. Thus, Boru and his colleagues write not only to convey information, but also to critique the regimes that control their lives and the lives of Kakuma residents-the state of Kenya, the UNHCR, and international aid organizations.

\section{Kenyan Refugee Policy and Kakuma Refugee Camp}

In order to understand the relations of force between KANERE and the agents of biopower, it is important to review the evolution of Kenyan refugee policy after 1990 and the subsequent creation of Kakuma refugee camp. According to Verdirame and Harrell-Bond, Kenya became a party to the 1951 Convention Relating to the Status of Refugees in 1966, and later to the 1967 Protocol, the 1969 OAU Convention, and main human rights treaties. 5 Until 1990, the Kenyan government handled refugee affairs and conducted status determination interviews with UNHCR advisory support. Because Kenya received minimal aid to support refugees, it exercised negligible oversight of asylees entering the country, allowing them to settle freely and find employment on their own. ${ }^{6}$ A small reception centre in Thika provided for destitute asylees while they awaited determination on their status. Those who were not granted asylum were allowed approximately three months to find another country. The government refrained from erecting obstacles to local integration,
(C) Author(s), 2016. This open-access work is licensed under a Creative Commons Attribution-NonCommercial 4.0 International license.
Cette oeuvre en libre accès fait l'object d'une licence Creative Commons Attribution-NonCommercial 4.0 International. 
therefore it was likely that most asylees remained in Nairobi. ${ }^{8}$ Some refugees managed to create secure livelihoods for themselves, despite the broader economic uncertainties facing the country. Others continued to live on the edge of survival, subject to economic insecurity and police harassment, although individual citizens, church leaders, and NGOs would take action on their behalf. 9 Kenyan refugee policy was forced to change after 1990 when more than 400,000 Somalis crossed into the country, fleeing violence and social upheaval, followed by the arrival of 7,00o Sudanese walking boys who were separated from their families when their villages were attacked. The reception centre in Thika, set up to house 350 individuals, was quickly overwhelmed with 8 , ooo refugees. ${ }^{10}$ These inflows prompted the government to appeal for foreign assistance. The prevailing political economy of aid driven by donor nations promoted control and containment of refugees. ${ }^{11}$ Thus, Kenya conceded to encampment as the most efficient way to manage the swelling refugee population. Subsequently, the UNHCR stepped in to establish and operate camps in border areas of the country-Mombasa, Dadaab, Mandera, and Kakumato receive entrants, and contracted with non-governmental organizations to provide specific services to the camps. ${ }^{12}$ The Kakuma camp, located in the Turkana District of northwestern Kenya, was constructed in 1992 to receive the Sudanese and has since expanded to receive refugees from Somalia, Ethiopia, Burundi, the Democratic Republic of Congo, Eritrea, Uganda, and Rwanda.

By $1996-7$, the UNHCR office in Kenya faced budgetary restrictions that led to the elimination of programs. The agency enacted a series of actions that were intended to reduce the refugee population and thereby justify its fiscal decisions. These actions included revalidation exercises (headcounts) to reduce the number of duplicate ration claims, the closure of the Mombasa camp, and the forced relocation of its residents to Dadaab or Kakuma, expecting that this would push some refugees to relocate to other countries or repatriate to their own. ${ }^{13}$ At this time, the UNHCR also assumed responsibility for status determinations.

Agier wrote that "by speaking only of circulations and flows, the management of entrants or the control of encumbrances, the question of the stateless is not just depoliticized, but dehumanized." ${ }^{4}$ The confinement of the majority of refugees in Kenya to refugee camps resulted in a state of exception, whereby governmental authorities transcended the rule of law guaranteeing non-refoulement and freedom of personhood. What was intended to be a short-term, emergency response to crises in neighbouring countries rapidly resulted in a "transient permanency" that immobilized them in isolated regions of the country, where they were unable to work or participate in public life. ${ }^{15}$ Kakuma and
Dadaab were described in the 2004 World Refugee Survey as "two of the worst examples of the long-term warehousing of refugees": "The camps are rife with human rights abuses: rape, domestic violence, and other crimes were common in the camps; traditional court systems imprisoned refugees for offenses including adultery that were not crimes under Kenyan or international law; and the local population clashed with refugees over resources like firewood."16

Verdirame and Harrell-Bond, in their Rights in Exile, likewise catalogued in great detail how refugees in Kenya routinely faced human rights abuses, primarily by their host government, although "UNHCR, NGOs, and refugee communities played a surprisingly prominent role in many violations."17

According to a March 2015 operational update from the UNHCR and Department of Refugee Affairs, 181,119 persons were registered as living in Kakuma. ${ }^{18}$ Their lives are marked by forced idleness and military control. Under these conditions, refugees become "negative political figures" unable to act on their own behalf, on even the most basic functions. ${ }^{19}$ Yet research has shown that the same conditions that produce refugee bare life can also be the ground for creative resistance and social engagement. Liisa Malkki's work with Hutu refugees in Tanzania showed that the "camp ended up being much more than a device of containment and enclosure; it grew into a locus of continual creative subversion and transformation." ${ }^{20}$ Likewise, Julie Peteet's engagement with Palestinian refugees in Lebanon revealed that refugee camps, "although spatially bounded units of governance ... are not necessarily spaces of passivity in which refugees wait hopelessly," but were dynamic and frequently contested places where they constructed a sense of meaning, identity, and place. ${ }^{21}$ Refugees-individually and collectively-improvise within the structural and disciplinary forces constraining their lives and, in the process, construct a social life beyond the bare life of the camp. ${ }^{22}$ It is from this ground of force relations that KANERE emerged.

\section{The Creation of KANERE}

Qaabata Boru was a second-year journalism student at Addis Ababa University when he was arrested and jailed for writing a news article that was claimed to have stirred tension at the university. While in detention, he was tortured and indicted as a supporter of a rebel group. Student protests prompted his release after two weeks; however, he continued to receive threats from the Ethiopian government, which has a long record of hostilities toward critical, independent journalists. ${ }^{23}$ The continued threats forced him to flee the country, leaving behind his family and abandoning his education. ${ }^{24}$ He arrived in Kakuma in 2005.
(C) Author(s), 2016. This open-access work is licensed under a Creative Commons Attribution-NonCommercial 4.0 International license.
Cette oeuvre en libre accès fait l'object d'une licence Creative Commons Attribution-NonCommercial 4.0 International. 
Boru described his life before exile as "full of happiness, protection with sense of security. It was so lovely-compassionate in sweet family dinner, free talk and everything was real!!"25 This sense of normalcy diminished when he fled and became a resident of Kakuma:

It was not easy to understand everything within the first few months. Camp life was such a confusing thing and it was like a new university for me; however, I saw and witnessed several incidents that made me critical of UNHCR/NGO's operations, incidents of insecurity and crimes: murders and killings, human rights abuses, sexual exploitation of girls, mistreatment of aid businesses along with other warehousing problems faced by the voiceless camp residents.

From 2006 through 2008-the camp was experiencing increased incidents of attacks and killings. By then I was working as a deputy H/Teacher in Unity Primary School, run by UNHCR / Lutheran World Federation. Some days the pupils did not come to school because people were killed in their community. [At] night or immediately after the sun set, communities patrolled their own demarcated borders as a form of providing security for themselves from attackers who were believed to be members of the host community. ${ }^{26}$

It soon became apparent to Boru that Kakuma's remote location made it possible for insecurities to continue unchecked, and for the authorities responsible for the welfare of the camp residents to avoid accountability for their inaction or perpetration of abuse. ${ }^{27}$ Boru appealed to the form of action that he knew best-that of the written word-working first within the primary school where he had influence:

I formed a journalism club where I taught a group of student in upper primary school about journalism. In a very simple way, the lessons continued periodically, by imparting them to understand "What is news?" In a few weeks the pupils were able to write down "news" happening within their communities and because school is a community where student are coming from all different parts of the camp, I was able to accommodate a lot of news/information happening around the camp. No sooner had I started incorporating the journalism club when several other school teachers joined. I started teaching and held periodic discussions as a way forward following the ongoing insecurity and killings. Sadly, because refugees have no capacity, we couldn't do any publication until I formed KANERE with a group of nine volunteers, of which seven were refugee teachers in the mid-2008. ${ }^{28}$

Boru and the others leveraged the project with the support of an American Fulbright scholar working in Kakuma, Bethany Ojalheto, who used financial resources from her research grant to launch the initiative. With its launch, KANERE became the first fully independent refugeerun news source of its kind to emerge from a refugee camp, using a WordPress blog platform that enabled it to reach international audiences. ${ }^{29}$

The first issue, posted on 22 December 2008, received thousands of hits from viewers worldwide. A limited number of print copies were available at tea shops and kiosks around the camp.

KANERE'S goals were twofold. First, it aimed to represent refugee voices in the camp, providing an avenue through which refugees at Kakuma could interact with and speak directly to the outside world, NGOs, and the camp's governing bodies. In doing so, KANERE could achieve its second goal, which was to expose abuses of power, violations of human rights, and exploitation connected with the distribution of food aid, and the negative impact of certain UNHCR policies in Kakuma..$^{30}$ KANERE's reporting categories included arts, business and development, community and culture, and Kakuma Town (among others). Boru was most interested in stories on human rights, crime and insecurity, corruption, and abuse:

I think these stories have a lot of significance because the camp residents have fallen victim of the story topics I have mentioned here above. They need legal and durable redress to their fates! By exposing and informing the camp residents about whatever is happening within the camp and their surrounds, they feel a sense of protection since the first-hand account of inhumane treatments or crimes are published. At the same time, the camp governing authority is held accountable for the same repression, violations of human rights and other forms of abuse on the beneficiaries of food aid. $3^{1}$

\section{The Case of MixMe}

A topic that generated significant discussion across several publications of KANERE was the distribution of MixMe, administered by the World Food Programme. MixMe is a micronutrient powder produced and donated by DSM, a global science-based company based in the Netherlands that is active in health, nutrition, and materials. Product distribution was in response to the high levels of anemia and micronutrient deficiencies found in refugee camps as a result of insufficient food rations ${ }^{32}$ The MixMe packets were distributed with the monthly food rations, with each beneficiary receiving a box of thirty one-gram sachets. The contents of the sachet were to be sprinkled over the food prepared in the home just before consumption. The intended outcome was to significantly reduce the prevalence of irondeficiency among Kakuma residents.

Despite its ease of use, along with an extensive communications campaign employing film, pamphlets, and plays to
(C) Author(s), 2016. This open-access work is licensed under a Creative Commons Attribution-NonCommercial 4.0 International license.
Cette oeuvre en libre accès fait l'object d'une licence Creative Commons Attribution-NonCommercial 4.0 International. 
promote proper use of MixMe, the product was not wellreceived by residents. ${ }^{33}$ Foremost among the complaints raised by residents was why an investment was made in what appeared to be a non-food product rather than local food production. ${ }^{34}$ KANERE staff collected residents' opinions of MixMe and posted their responses verbatim in the Community Talking Points section of the March-April 2009 issue of KANERE:

It's okay, but vitamins are also found in meat, vegetables, etc. Why couldn't WFP supply local food containing these vitamins and minerals? (Anne, Somalia)

It makes people have diarrhea and you know this place is too hot and if you don't get medical attention fast, then you can easily die due to dehydration. Why can't UnHCR do away with Mix Me and instead bring enough water to the people? (Zarah, Somalia)

When consumed, Mix Me increases the appetite and people develop a state of eating too much. While wFP offers little quantity calculated for only 15 days, we've been finding ourselves in condition of food stock out before the expected time-four days before reaching the 15 th day. (Bisengo, Congo)

When I first took Mix Me I experienced some stomach disorder and I became very weak. People fear the sign on the sachet of Mix Me. They think it is an animal and so they think Mix Me is for animals and not people to consume. (Student, Jebel Mara Primary School)

It is good and we like it. It should always be given out but some people have to be made aware of it because many people have misunderstood it. (Mark, Sudan)

The powdery appearance of MixMe, combined with the fact that its distribution was limited to refugee camps, raised additional concerns about the integrity of the product. Individuals who spoke to KANERE reporters asked a variety of questions, ranging from the content of the ingredients and whether they would conflict with religious dietary restrictions, to the protocol and decisionmaking behind the allocation of MixMe to Kakuma refugeesand not to Dadaab refugees, or consumers at local markets and shops, or among aid staff. Specifically, residents wanted to know if MixMe was a product trial, and if they were the "guinea pigs" for testing the effectiveness of the product. These questions reflected a heightened sensitivity among residents to the vulnerability of their situation: "The way we see Mix Me as refugees seems to be having a secret behind it that is not yet clear, but transparency will still come out. Can WFP change this Mix Me into locally available or locally produced food rather than bringing externally produced chemicals that are harmful to refugees, who are used as laboratory animals for someone's university research?” (Anonymous, Congo)

The residents' perception of MixMe as a chemical showed as well the proliferation of rumours surrounding the product rollout. The rumours, which included speculations that MixMe was a family-planning drug, demonstrated the kind of suspicions harboured by the refugees toward aid efforts: "People don't want this stuff, as it has created many different perceptions among the refugees ... It also has no country where it was manufactured, and expiration date is not visible clearly. If it is good for human consumption, then even Kenyans should be able to get it or buy it in the shops, but it is not in shops. Why?" (Jebel Mara Primary School student)

The refugees' lack of choice in receiving a product perceived as exotic in a context where they were already denied choice generated fear and mistrust. According to Simon Turner's research in Lukole camp (Tanzania), rumours functioned to impose order in conditions of insecurity, especially in relation to "big actors" and the "big nations." 35 Other researchers have likewise noted that the circulation of rumour represents a form of collective resistance and "call to action" deployed by groups in ambiguous situations attempting to negotiate their circumstances. ${ }^{36}$ Similarly, the discourse of suspicion around MixMe reflected the anxieties of Kakuma refugees in relation to the regimes controlling their bodily lives. ${ }^{37}$

KANERE sought to address the questions raised by refugees by approaching World Food Programme officials in the camp for answers. Some of the questions pertaining to nutritional content were publicly available, and KANERE responded with the information in their articles on the MixMe topic. ${ }^{38}$ However, KANERE was unable to secure face-to-face interviews. According to Boru, some officials claimed to be too busy to meet. Others, such as Lourdes Ibarra, refused a meeting based on KANERE's independent status. She indicated that the organization would not provide information to KANERE until the free press was registered as a community-based organization (generally recognized in Kenya as self-help groups). She gave no explanation for why сво status was required in order for an interview to occur. Yet the decision by the organization to distance themselves from the concerns of the residents reinforced the suspicions circulating about the product.

KANERE's interaction with the World Food Programme demonstrated the kind of unresponsiveness many refugees encountered when attempting to communicate their concerns to camp authorities and humanitarian organizations. Jajj discovered that refugees were expected to negotiate the camp hierarchy through community representatives, who conveyed their concerns to authorities. However, the
(C) Author(s), 2016. This open-access work is licensed under a Creative Commons Attribution-NonCommercial 4.0 International license.
Cette oeuvre en libre accès fait l'object d'une licence Creative Commons Attribution-NonCommercial 4.0 International. 
hierarchy functioned to protect the camp bureaucracy, reinforcing "the control and maintenance of social distance between camp administration and aid agencies on the one hand and refugees on the other." 39

The MixMe controversy illustrates refugee resistance to biopower. Clearly, the residents resisted being viewed as undifferentiated bodies available for experimentation. They demonstrated their resistance through a 70 per cent refusal of the product, resulting in MixMe sachets being littered across the camp..$^{\circ}$ Despite the widespread rejection of the MixMe product, a joint report on the use of the micronutrient in the Kakuma Refugee Camp, prepared by the UNHCR, the World Food Programme, and Dsm stated, "An initial trial with MNP showed high acceptability by mothers who acknowledged improvement in the health of their children, saying that they were looking healthy, playing more and had an increased appetite." 41 Ironically, the waste of MixMe sachets created a new employment opportunity for refugees who were hired to collect the discarded sachets.

A DSM designee on a fact-finding mission at Kakuma camp in 2009 observed the waste of the MixMe product. In a blog maintained for friends and family, the designee expressed her astonishment at the refugees' rejection of the product: "Can you imagine, refugees, I repeat, refugees, who have basically nothing, going to the food distribution standing in line to pick up their ration of food, and then just leaving the boxes of Mix Me there." The designee stated that it hurt her to see the sachets lying around on the ground all over the camp because she was "so convinced that it is good for them, and I watch them struggle to survive even, and for a short moment I felt like they do not want to accept our help." 42

Even as she grappled with the recognition of refugees' concerns, the subtext of the MixMe designee was clear: the refugees needed to be convinced that the product was something they should use. The efficient management of refugee health and well-being had to be regulated through the deployment of a biotechnology that reduced the frequency of serious medical issues without changing the actual conditions of the camp. The designee's astonishment that the act of refusal was perpetrated by refugees ("can you imagine refugees, I repeat, refugees who have basically nothing”) reinforced a bio-political view that regarded the vulnerable as bodies stripped of political standing or citizenship rights.

The discourse of suspicion characterizing the collective response to MixMe provided valuable insight into the critical relations between Kakuma refugees and the governing agencies that managed the camp. As a case study of resistance within a framework of biopower, the MixMe controversy demonstrated the enactment of agency that disrupted existing relations. Agamben wrote that "humanitarian organizations ... can only grasp human life in the figure of bare or sacred life, and therefore, despite themselves, maintain a secret solidarity with the very powers they set out to fight." 43 Yet the MixMe controversy demonstrated a push back to the sovereignty of state and aid over the refugees' natural lives.

\section{A Transgressive Sphere}

KANERE played an important role in the MixMe controversy by constructing a narrative of resistance that countered the public relations of UNHCR and its subcontractors. As a free press, KANERE provided a space for the production of a public sphere that transgressed the restrictive environment of the refugee camp. Within Kakuma, KANERE gives refugees a platform for speaking directly to various publics, including the aid agencies, about their experiences. Additionally, KANERE contributed to a body politic that transcended national affiliations yet built upon a common identity marked by displacement, insecurity, confinement, and the longing for resolution. "Only a community of existence, based on shared experience and lived situation, can then unite these anonymous crowds in a history made up of violent disruptions, then an administrative category of identity ('refugees,' etc.), and finally a special security and humanitarian treatment. Confined in spaces that are out-places, they see their political existence depends no longer (or not only) on their origins, but on local contexts of identification." 44 KANERE's mission as a free press not only informed and reported, but also countered what Boru described as the monopoly of information enjoyed by humanitarian organizations that largely controlled access to and information about refugee camps. "It is here that collective actions undertaken ... acquire their political meaning, when the occupants of the camps intervene on the terrain that is allocated to them, to demand social rights attaching to their present condition." 45

KANERE's representation of the refugee camp exposed realities that were typically hidden in the efficient reports of the UNHCR and their NGO subcontractors. According to Verdirame and Harrell-Bond, donor nations and the international community have typically relied upon UNHCR and NGO reports, without giving balanced consideration to the reports of journalists, activists, academic researchers, or the refugees themselves. ${ }^{46}$ Consequently, information circulated about refugee lives and camp conditions was conveyed through the orderly compilation of statistics and influenced by concerns of "image management" and "the impulse to insert a utopian description" over dystopian realities. 47 Similarly, occasions such as World Refugee Day were spectacles that featured speech-making by dignitaries and cultural pageantry, with refugees wearing traditional clothing
(C) Author(s), 2016. This open-access work is licensed under a Creative Commons Attribution-NonCommercial 4.0 International license.
Cette oeuvre en libre accès fait l'object d'une licence Creative Commons Attribution-NonCommercial 4.0 International. 
and performing songs and dances from their countries. KANERE's coverage of World Refugee Day highlighted the indignities of the event that required most refugees to walk up to five kilometres to participate, and then stand in the hot sun to watch, while humanitarian NGOs were seated in the shade with cold refreshments. ${ }^{48}$ As the comments from the KANERE July 2012 Community Talking Points show, the refugees interviewed generally did not share the celebratory spirit of the day: 49

I see no meaning of this day. I have lived here for 6 years with no recognition from both UNHCR and Kenya government. My desire is to go back home when peace prevail in my homeland. (Wechtour, Ethiopian Nuer leader)

This day makes me feel very sad; I am a voluntary prisoner in Kakuma. I can't move freely. I don't see any reason for cheering the day. We should rather preach peace to prevail in the world. Everything is corrupted here, let the UNHCR think right and give us quicker durable solution. (Elros, Ethiopia)

Refugee Day should be commemorated in a special way by giving refugees special gifts or special food ration during the distribution cycle rather than inviting them to dance, I hate that practice. (Ingabine Rose, Congolese)

Being a refugee is bad. You are deprived of most of your rights and freedom. I don't see the purpose of music and dances to make UNHCR and NGOs pleased yet there's no recognition in it. (Rukunda Jean, Rwanda)

Intriguingly, one of the comments posted to the July 2012 World Refugee Day article on the KANERE site was from an Eastern European refugee who signed off as "Victim of the UNHCR": "Being a refugee is a very hard task because of the Refugee's protector-the UNHCR. The UNHCR is destroying me in Ukraine for more than 8 years. I am half abnormal now; because of the UNHCR, my life has changed in a nightmare. Why has the world society has found such a corrupted system that affect people to such extent?"

\section{An Ethic of Risk}

As indicated earlier, the KANERE editorial team was not the first effort to operate a refugee press. From 1993 to 2005, the United Nations ran the Kakuma News Bulletin (KANEBU), which functioned as a newsletter to share information about events occurring throughout the camp. While KANEBU engaged refugee journalists in writing articles for the newsletter, the local UNHCR unit retained editorial control of what was actually published. KANERE set out from the beginning to produce a news source that was different from KANEBU.
First, KANERE would operate independent of UNHCR authority so that it could fulfill its critical purpose rather than function as a public relations tool for the UNHCR. Second, KANERE would use a WordPress blog on the Internet as its media source, thereby reaching beyond the geographic isolation of the Kakuma Camp to establish a borderless format with the potential to reach a global audience.

KANERE'S decision to maintain itself as a free press had grave risks. Soon after its initial publication in December 2008, objections were raised by the UNHCR about its lack of participation, citing concerns over confidentiality, protection of identities of people living in the camp, and ethical standards of reporting. In response, Boru and his colleagues stopped providing article bylines and using the full names of residents, and removed two sensitive articles. Even with its critical mission, KANERE intended to work cooperatively with the UNHCR and aid agencies: "Kanere staff always approach NGO officials for citations for the stories they work on but since UNHCR and its sister partners have jointly illcommunicated against Kanere because we denied UNHCR censorship, there has been no good relationships since its inception. However, Kanere journalist do always approach the humanitarian offices for official comments. When they fail to cooperate, Kanere officials record all the attempts made towards balanced reporting. And yet [UNHCR/NGOs] keep on violating their own policy by refusing to speak with press!"5o

A difficulty KANERE faced in advancing its work was noncooperation or non-response by UNHCR officials, who used their bureaucratic influence to block efforts. ${ }^{51}$ According to an article prepared for the Society for International Development Forum, Olajheto reported that KANERE received a letter from the UNHCR head of suboffice, Mohamed Qassim, stating that the UNHCR "cannot support the pure independence" of a free press that receives the support of "relief funds." He further stated that KANERE did not demonstrate how it added value to the refugee program, therefore support would not be forthcoming until the UNHCR was convinced that the news source served the interest of the camp. Boru responded, "I will not like at any point to collaborate with a UNHCR who [is going to] restrict my work. I wish to work with a free mind, with a full consciousness, without restrictions of what to do and don't, however there are no written documents from UNHCR, but only verbal alerts."52

Other challenges KANERE faced were more overtphysical attacks, verbal threats, theft of equipment, and libellous charges, usually from other refugees who feared that associating with KANERE would jeopardize their resettlement chances. This fear was not wholly unfounded. On several occasions, refugee journalists were interrogated about their involvement with KANERE by protection staff,
(C) Author(s), 2016. This open-access work is licensed under a Creative Commons Attribution-NonCommercial 4.0 International license.
Cette oeuvre en libre accès fait l'object d'une licence Creative Commons Attribution-NonCommercial 4.0 International. 
and one was warned to "keep his distance" because involvement in activities that "UNHCR does not like" could put his incentive job at risk..$^{53}$ As a consequence of these security threats, the KANERE team dropped from its initial twenty reporters to fifteen and then to its current number of seven active journalists. 54

Articles in Pambazuka News covered a series of incidents in which KANERE was targeted: its registration papers for community-based organization status were confiscated; 55 Boru was assaulted, his home vandalized and set on fire, ${ }^{56}$ and his requests for legal protection were ignored.57 Ojalehito, who collaborated in the launch of KANERE, was told that her work on KANERE was not relevant to her research and therefore she could lose her housing through the Lutheran World Federation. $5^{8}$ KANERE journalists regarded these threats as a direct challenge to refugee voice. "Refugee journalists fear opposing the UNHCR, but their desire to struggle for a free press is stronger." 59

KANERE made modest headway in its negotiations with the UNHCR after Dr. Ekuru Aukot, an international human rights lawyer with Kituo Cha Sheria, visited Kakuma and wrote an editorial responding to the question of whether refugees in Kenya had the right to a free press. Aukot's article appealed to ratified legal documents, including the Refugees Act of 2006 and the Constitution of Kenya, to clarify that refugees enjoyed the right to freedom of expression through a free press, provided they followed the ethical standards for journalism. He wrote,

A free press particularly is often interpreted differently depending on what interests are at stake, and on what the free press is exposing or about to expose. States may restrict this right in the excuse of national security. Other authorities such as humanitarian agencies may restrict its enjoyment owing to the fact that to allow refugees, for example, to exercise this right fully may cause embarrassment and would open a series of criticism ... No one should see KANERE as threatening, for example, the security of Kenya, for that is often what typical bureaucrats would argue. There are more worrying and pressing things in Kenya at the moment than to worry about the freedom of individuals to speak out, whether exercised by refugees or Kenyans. ${ }^{60}$

In addition to offering valuable legal support to the legitimacy of KANERE's work, Aukot also exposed the fallacies behind the security arguments upon which the Kenyan government and the UNHCR based their opposition, stating decisively that inhibiting the right to a free press was in direct violation of the Kenyan Constitution. In response to Aukot's editorial on behalf of KANERE, the local UNHCR unit agreed to provide the letter of support needed by KANERE to proceed with its application for Сво recognition. But its support remained conditional on its involvement, arguing that a free press couldn't be purely independent if it was receiving relief funds. KANERE refused these conditions.

During the spring of 2013, the Refugee Newsletter was released in Kakuma. Ostensibly, the newsletter was written and published by refugee youth in a journalism program sponsored by FilmAid. The six-page document was full colour with professional layout, and acknowledged support from the United States Bureau of Population, Refugees, and Migration. The lead article headlined "A New Dawn for Journalism in Kakuma," claiming that the refugee community now had a platform to tell their stories. There was no recognition of KANERE'S work. In Boru's opinion, the newsletter was a "countermeasure to oppose Kanere and mitigate the effect of media by contrary action, which is intended to compete with Kanere." ${ }^{\prime 1}$ Boru also worried that the FilmAid newsletter would confuse international readers who searched for the Kakuma refugee newsletter and found the Refugee Newsletter instead. Boru wrote a public response in the August 2013 publication of KANERE, entitled "New NGO Run-Newsletter Enhances News Access in Kakuma." While the article assumed a conciliatory tone, welcoming the effort and emphasizing the value of multiple sources of news, it drew a sharp distinction between the purposes of each: "According to those of us here at KANERE, the more new voices that emerge, the better that it will shape media environment. There's room for both the NGO-run and a refugee-run newsletter because each media outlet has a different purpose and function ... Going forward, what kind of journalism do we hope is practiced in Kakuma? Journalism that serves democracy and is genuinely interested in exposing issues of public importance would be the kind of the journalism that deserves protection." ${ }^{2}$

By continually referencing the Refugee Newsletter as the NGo-run newsletter, Boru resisted the claim that the newsletter represented authentic refugee voice, thereby speaking back to any insidious measures that may have threatened erasure of refugee critique.

As of this writing, KANERE continues to function, although precariously. Despite its resource difficulties and its continued problems with camp authorities, KANERE has gained traction. Internally, KANERE has growing support among community leaders within the camp who participate in the circulation of news and information to be included in KANERE reporting. KANERE has also gained an ever-expanding coalition of supporters worldwide. According to the Humanitarian Futures Programme blog, KANERE "is an absolutely fantastic example of citizen journalism, empowered by the web, completely changing the game of humanitarian business," with the potential to catalyze "the next stage of growth for the aid industry." 63 The Refugee Research Network translates KANERE into Japanese.
(C) Author(s), 2016. This open-access work is licensed under a Creative Commons Attribution-NonCommercial 4.0 International license.
Cette oeuvre en libre accès fait l'object d'une licence Creative Commons Attribution-NonCommercial 4.0 International. 
Alternative news sources such as Pambazuka News (multiple issues), Society for International Development Forum (October 2, 2009), McGill Daily (3 November 2009), and Forced Migration Review (August 2012) have featured KANERE. Boru was interviewed for a short video by the Commission to Protect Journalists on exiled East African journalists who continue to work in communications outside of their countries. A North American photographer, Dustin Barter, launched a crowd-funding campaign on Indiegogo to purchase laptops and construct a fully equipped, solar-powered office. A group of international supporters of KANERE, which includes the author, reopened the campaign in the spring 2016. ${ }^{64}$ In November 2013, KANERE announced that it obtained its registration status as a national non-governmental organization in Kenya. It strongly welcomes further collaboration from all government departments within Turkana County, the Department of Refugee Affairs, the UNHCR head of suboffice, and other humanitarian agencies in Kakuma. KANERE's global reach gives power to the narrative of the political refugee subject. This narrative is formed discursively from the stories, poems, opinions, interviews, photographs, cartoons, and news collected from districts of the Kakuma camp. Likewise, the story continues to be told in conversation with its global audiences of human rights advocates, resettled refugees, and other communities of solidarity.

\section{Conclusion: Does KANERE Make a Difference?}

Does KANERE make a difference? Boru believes that KANERE'S advocacy for refugee rights has prompted improvements in refugee services, including installation of solar lamps in the camp and the deployment of more police to patrol the camp following reports on security problems. Also, in response to KANERE's reports of inadequate attention to refugee complaints, the UNHCR established field posts throughout the camp so that refugees can speak directly to UNHCR officials. ${ }^{65}$

KANERE also contributes to educational and social development through its journalism training for youth. Similarly, working journalists are able to continue their craft, even though they do so without compensation. Finally, KANERE's work has helped to promote social cohesion among residents through information sharing and awareness of current issues and concerns.

But is asking about material impact the right question? If success is determined by how quickly or effectively KANERE transforms policies of encampment or the operations of Kakuma camp, then its efforts may be perceived as inconsequential. The fact that KANERE survived and has gained an international audience, despite the bureaucratic, physical, and economic threats it has faced, is remarkable. Within the framework of biopower, the actualization of dissent disrupts efficient management and needs to be neutralized. KANERE's persistence produces a narrative of the politicized refugee subject. Through it we witness a relation of force grounded in an ethic of risk whereby individuals act despite the odds that are against them. ${ }^{66}$ KANERE journalists write because they must, because doing so exercises and creates another sort of power, one that is based in the dangerous memories of suffering and loss. From these memories "a critique of existing institutions and ideologies that blur the recognition and denunciation of injustice" is given voice. ${ }^{67}$

Michele C. Deramo is director of Diversity Education and Initiatives and a doctoral candidate in social and cultural theory at Virginia Tech. The author may be contacted at deramo@vt.edu.

\section{Notes}

1 Michel Foucault, The History of Sexuality: An Introduction, vol. 1 (New York: Vintage, 1978).

2 Ibid., 140.

3 Rose Jajj, "Social Technology and Refugee Encampment in Kenya," Journal of Refugee Studies 25, no. 2 (2011): 233.

4 L. Tuhiwai Smith, Decolonizing Methodologies (New York: Zed Books, 2012).

5 Guglielmo Verdirame and Barbara Harrell-Bond, Rights in Exile: Janus-Faced Humanitarianism (New York: Berghan Books, 2005), 28.

6 Ibid., 31.

Ibid.

8 Ibid., 32.

9 Ibid.

10 Ibid., 33.

11 Ibid., 278.

12 Ibid., 33 .

13 Ibid., 34-5.

14 Michel Agier, Managing the Undesireables: Refugee Camps and Humanitarian Government, trans. David Fernbach (Malden, MA: Polity, 2011), 12.

15 Bulent Diken, "From Refugee Camps to Gated Communities: Biopolitics and the End of the City," Citizenship Studies 8, no. 1 (2004): 94.

16 Merrill Smith, "Warehousing Refugees: A Denial of Rights, a Waste of Humanity," World Refugee Survey, 2004.

17 Verdirame and Harrell-Bond, Rights in Exile, 120.

18 Data from the Kakuma Operational Update, 13-19 March, 2015, UNHCR.

19 Agier, Managing the Undesirables, 18. 
20 Liisa H. Malkki, Purity and Exile, Violence, Memory, and National Cosmology among Hutu Refugees in Tanzania (Chicago: University of Chicago Press, 1995), 36-7.

21 Julie Peteet, Landscape of Hope and Despair: Palestinian Refugee Camps (Philadelphia: University of Pennsylvania Press, 2005).

22 Bram J. Jansen, "Two Decades of Ordering Refugees: The Development of Institutional Multiplicity in Kenya's Kakuma Refugee Camp," in Disasater, Conflict and Society in Crises: Everyday Politics of Crisis Response, ed. Dorothea Hilhorst, 114-31. (New York: Routledge, 2013).

23 According to data collected by the Committee to Protect Journalists, Ethiopia has driven more journalists into exile than any country in the world: seventy-nine since 2001. See Committee to Protect Journalists, http:// www.cpj.org.

24 Details of Boru's life before arriving in Kakuma were drawn from email communications as well as an interview by Andrew McGregor. See "Keeping the News Alive from Outside Ethiopia: Andrew McGregor Interviews Qaabata Boru," Provocations: A Special Series on Freedom of Expression, Los Angeles Review of Books, 24 October 2013.

25 Email correspondence, 15 April 2013.

26 Ibid.

27 Boru links Kakuma's remote location to the prevalence of human rights abuses and the need for a news source to expose these abuses. He cites several reports, including the video Journalists in Exile: Crisis in East Africa, produced by the Committee to Protect Journalists, 19 June 2012, https://www.cpj.org/blog/2012/o6/videojournalists-in-exile.php, and the KANERE entry in the African News Innovation Challenge, summer 2012.

28 Email correspondence, 15 April 2013.

29 Other camps had refugee newsletters, but they typically operated with the support and oversight of NGOs to share news internally. According to Barbara HarrellBond, refugees have produced their own news sources in every camp she visited; however, these efforts were crushed by camp administration (informal conversation March 2014).

30 Editorial Staff, "KANERE: A Refugee Run Free Press in Kakuma," Forced Migration Review 40 (2012), http://www .fmreview.org/en/young-and-out-of-place/kanere.pdf.

31 Email correspondence, 15 April 2013.

32 The International Rescue Committee and UNHCR conducted a nutrition survey at Kakuma refugee camp in 2007 and discovered that 86.7 per cent of the children and 40.6 per cent of the women were anemic. The survey is referenced in Micronutrient Powder (MixMe $e^{\mathrm{TM}}$ )
Use in Kakuma Refugee Camp in Kenya (Africa) 1, no. 3 (May 2009), produced by the World Food Programme, DSM, and the UNHCR.

33 Editorial Staff, "MixMe Nutritional Supplement Raises Questions," Kakuma News Reflector 1, nos. 4-5 (March-April 2009), http://kanere.org/2009/05/12/ mixme-nutritional-supplement-raises-questions/.

34 In fact, micronutrient powders such as MixMe are food-based rather than medicinal in origin.

35 Simon Turner, "Under the Gaze of the 'Big Nations': Refugees, Rumours and the International Community in Tanzania," African Affairs 103, no. 441 (2004): 238.

36 Jun Liu, "Rumor, Mobile Phone, and Resistance in Contemporary China," paper presented at "Media in Transition 8" conference, 3 May 2013, MIT, https://lup.lub.lu.se/ search/publication/3768446.

37 While Kakuma residents questioned why they were selected to receive MixMe, local Turkana residents who were queried asked why they were not able to access the product since their nutritional needs and health issues were the same as the refugees': "Local people have not been given or benefited from Mix Me" (Dorcas Ewoi, Turkana), "Community Talking Points: MixMe," Kakuma News Reflector 1, nos. 4-5 (March-April 2009), http:// kanere.org/2009/05/12/community-talking-point-mixme/.

38 Editorial Staff, "World Food Programme Kicks Off 2nd Mix-Me Nutritional Supplement Survey," Kanere News Reflector, 22 December 2009, http://kanere.org/2009/12/22/ world-food-program-kicks-off-2nd-mix-me-nutritionalsupplement-survey/.

39 Jajj, "Social Technology and Refugee Encampment," 229.

40 Editorial Staff, "World Food Programme Kicks Off."

41 Micronutrient Powder (MixMe) Use.

42 Evelina Rok, "My Future Is so Bright I Need Sunglasses," blog, 10 July 2009.

43 Giorgio Agamben, Homo Sacer: Sovereign Power and Bare Life, trans. Daniel Heller-Roazen (Redwood City, CA: Stanford University Press, 1995), 133.

44 Agier, "Managing the Undesirables," 17.

45 Ibid.

46 Verdirame and Harrell-Bond, Rights in Exile, 298.

47

, 299. The authors reference a 1999 protection report for Kenya that included a long list of enrichment activities offered at Kakuma that sounded more "like a brochure for a summer camp" than a report about refugee children, that included the Sudanese walking boys, "one of the most deprived, traumatized, and malnourished groups of adolescents in the world" (300). They also reference in an endnote a 1994 UNICEF report, Children of War: Wandering Alone in Southern 
Sudan, which claimed that the thousands of Sudanese unaccompanied minors could resume normalcy upon arriving at Kakuma (328n51).

48 Qaabata Boru, "World Refugee Day: Kakuma at a Glance," Kanere News Reflector, 28 August 2013, http:// kanere.org/2013/o8/28/world-refugee-day-kakumaat-a-glance/. Also "World Refugee Day," Kanere News Reflector, 23 July 2012, http://kanere.org/2012/07/23/worldrefugee-day/; and "World Refugee Day," Kanere News Reflector, 16 August 2014, http://kanere.org/2014/o8/16/ world-refugee-day-2014/.

49 Editorial Staff, "Community Talking Point: World Refugee Day," Kakuma News Reflector, 23 July 2012, http://kanere.org/2012/07/23/ community-talking-point-world-refugee-day/.

50 Email correspondence, 15 April 2013.

51 KANERE'S experience was consistent with the findings of Verdirame and Harrell-Bond, who observed that the UNHCR had a record of mounting obstacles to refugee associations, and to researchers or external reporters who might write negatively about their work. Rights in Exile, 198-200.

52 Bethany Ojalheto, "Refugee Free Press Struggling to Remain Afloat and Independent," Society for International Development, 1 October 2009, http://www.sidint. net/content/refugee-free-press-struggling-remain-afloatand-independent.

53 Ibid.

54 McGregor, "Keeping the News Alive."

55 Editorial Staff, "Refugee Free Press at Crossroads," Pambazuka News, 7 July 2009, http://www.pambazuka.net/en/ category.php/refugees/57613.

56 Qaabata Boru, "KANERE Refugee Free Press Editor Assaulted," Pambazuka News, 3 December 2009, http:// www.pambazuka.net/en/category.php/letters/60698.
57 Bethany Ohalheto, "Refugee News Reporting Project under Threat," Pambazuka News, 18 March 2010, http:// pambazuka.org/en/category/features/63143.

58 Ibid.

59 Qaabata Boru, "Freedom of the Press," McGill Daily, 3 November 2009, http://www.mcgilldaily.com/2009/11/ freedom_of_the_press/.

6o Ekuru Aukot, "Who Believes in the Rights of Immigrants? Do Refugees Have the Right to a Free Press?" Kakuma News Reflector 1, no. 3 (February 2009), https://kanere. org/2009/02/28/who-believes-in-the-rights-of-immigrants-do-refugees-in-kenya-have-the-right-to-a-freepress/.

61 Email communication, 13 May 2013.

62 Qaabata Boru, "New NGo Run-Newsletter Enhances News Access in Kakuma," Kakuma News Reflector, 18 August 2013, http://kanere.org/2013/o8/28/new-ngo-run-newsletter-enhances-news-access-in-kakuma-2/.

63 "Kakuman Refugee Newsletter," Humanitarian Futures Programme, February 2009, https://humanitarianfutures. wordpress.com/2009/02/02/kakuma-refugee-newsletter/.

64 See crowdsource campaign, "KANERE Refugee Free Press," Generosity, https://www.generosity.com/ fundraising/kanere-refugee-free-press.

65 Editorial, "KAnerE: A Refugee-Run Free Press in Kenya," Kakuma News Reflector, August 2012, http://www.fmreview.org/en/young-and-out-of-place/kanere.pdf.

66 Sharon Welch, 2000. A Feminist Ethic of Risk (Minneapolis: Fortress, 2000).

67 Ibid., 155. 


\title{
Book Reviews
}

\author{
Postcolonial Life Narratives: Testimonial Transactions \\ n \\ Gillian Whitlock \\ Oxford: Oxford University Press, 2015, pp. 242
}

$\mathrm{G}$ illian Whitlock's new book, Postcolonial Life Narratives: Testimonial Transactions, is a remarkable contribution to burgeoning interdisciplinary work on narrative, human rights, refugees, and trauma. Written in crisp, lucid prose, Whitlock's work introduces readers to a full range of theoretical and archival approaches to postcolonial life-writing, tracking memoir, and testimony from the eighteenth to the twenty-first century. Whitlock begins in the eighteenth century because, as she and others have argued, the self as author of the individualist life narrative was an Enlightenment invention, inaugurated by the Confessions of Jean-Jacques Rousseau. But Whitlock sidelines Rousseau to focus instead upon the life narratives of Rousseau's less canonical contemporaries, Olaudah Equiano and Watkin Tench (both 1789), the former a freed slave who participated in the movement to abolish the slave trade and the latter a Marine officer best known for his first-hand account of the new penal settlement at Port Jackson, New South Wales. Whitlock portrays Equiano's and Tench's narratives as alternative starting points for conceptualizing the history of life-writing, emphasizing their seminal importance as texts that participate in what Lynn Hunt has characterized as the "invention of human rights" through literature. However, while the missions of Equiano's and Tench's narratives are similar-essentially, soliciting "benevolent witness" (22)-Whitlock is more interested in their critical differences. Indeed, the contrast Whitlock draws between the two narratives structures the ethical binary that defines Whitlock's study: namely, the difference between Tench's "detached" role as spectator of suffering (which she models upon the moral philosophy of Adam Smith) and the "anguished" spectatorship that Equiano invokes (which she models upon the aesthetics of Edmund Burke). As Whitlock explains, humanitarian narratives have for more than two centuries been haunted by these unstable borders between compassion and voyeurism, between giving voice and taking voice.

In case studies ranging from biographies of Saartjie Baartman, known as the Hottentot Venus, to Dave Eggers's novelization of Achak Deng's testimony as a Lost Boy in What Is the What, Whitlock details the ethical double binds that beset rights writing. She explains, "Humanitarian storytelling has the power to create spectators of suffering who engage empathetically with terrible events. It generates compassion and benevolence, and elicits donor support. At the same time, it can be called to account for the part it plays in representing communities and people as inhabitants of a 'developing world,' and as subjects of 'distant suffering' offered for Western benevolence and spectatorship" (110).

Spanning the globe and the centuries, Whitlock discovers example after painful example of the way acts of rescue and care are converted into harm. Discussing the writings of journalist and anti-apartheid activist Antjie Krog, Whitlock explains that the South African Truth and Reconciliation Commission (TRC) worked to defend the integrity of survivor and cultural memory but also inflicted new forms of injury, particularly insofar as it pressured survivors to forgive in the name of national unity. As Whitlock demonstrates with the case of survivor Notrose Nobomvu Konile, who refused "to forgive and adopt the reconciliatory politics of the TRC" (90), the TRC quite literally erased testimony that was not easily assimilable into narratives of cultural healing. While the TRC's final report on its activities frequently described the therapeutic value of giving survivors a chance to tell their stories, many involved in the process insisted that it also reopened old wounds.

Discussing Sally Morgan's My Place, an autobiography of the Stolen Generations in Australia, Whitlock explains how attempts to memorialize trauma to indigenous children 
created a discourse that ultimately reproduced it. She cites a 2007 report on the welfare of children in the Northern Territory, "Little Children Are Sacred," which prompted forceful intervention and policing of indigenous communities. "The trope of the suffering child," she writes, functioned "to legitimate intervention as well as reconciliation" and was readily appropriated into Australia's neo-colonialist "campaigns to 'manage' indigeneity" (164). Discussing biographies of Dian Fossey alongside accounts of conflict in the Democratic Republic of the Congo, Whitlock exposes the historical failure of humanitarian campaigns to address rape and rape warfare: in the history of humanitarian work, some things have been speakable and others have not. Just so, in her concluding studies focusing upon refugee narratives, Whitlock uses the work of Edwidge Danticat and others to dramatize how the global infrastructure of human rights and humanitarianism has turned the refugee into a narratable identity only through restrictions and exclusions. "Asylum-seekers must master the codes and conventions of the acceptable narrative in the performance of their testimony," she explains. "They are required to match their subjective life experiences to the objective parameters of asylum policy to achieve credibility within the asylum determination procedure" (182).

As Whitlock emphasizes, the work of rights writing is the work of exposure. We shine a light on atrocities when they are happening to motivate international actors to intervene. We detail and record atrocities from the near past to aid the work of truth and reconciliation, and from the deeper past to defend the integrity of survivor and cultural memory. Silence, as it has been argued in genocide studies, is a kind of second death. But if trauma demands representation in this way, it also resists representation. It is difficult to tell stories of sensational atrocities without crossing the line into sensationalism. And if survivors of atrocity are injured by denial and silence, they are also injured by being turned into commodity artifacts for a global emotional market of human rights voyeurs. Whitlock's new study is an important contribution to scholarly and activist work that seeks to guard against the harms that come from blindness to these moral risks.

James Dawes is the DeWitt Wallace Professor of English at Macalester College. He may be contacted at Dawes@Macalester.edu.

\section{Refugees of the Revolution: Experiences of Palestinian Exile \\ $\curvearrowright$ \\ Diana Allan \\ Stanford, CA: Stanford University Press, 2014, pp. 328}

I n 2002, anthropologist Diana Allan embarked upon a project to establish an archive of filmed testimonies of first-generation Palestinian refugees living in the Shatila refugee camp in Lebanon. However, during the recording of the stories another narrative emerged, which changed the course of her research and led to Refugees of the Revolution: Experiences of Palestinian Exile. Allan identified a stark discrepancy between the nationalist meta-narratives of belonging and return being produced in formal interviews for the archive, and the micro-narratives of daily struggle and resistance that emerged in casual, everyday exchanges. After three years in the camp, she arrived at her core assertion: that refugees in Shatila should not be seen primarily as living symbols of the Palestinian struggle, nor should their experiences be understood solely through the lens of national attachment. Rather, their identity is constituted daily through the local, material worlds they inhabit.

Allan's phenomenological study contributes to the narrative turn in forced migration research, placing refugee narratives at its heart. By combining ethnographic observations with quotations from informal interactions and formal narrative interviews, she reveals that daily life in the camp constitutes a struggle that is economic and existential, as well as political. The ten photographs included in the book, by Shatila photographer Hisham Ghuzlan, offer further insight into camp life through visual narrative. Allan brings the book to life with narrative extracts, which provide a window on poignant dramas unfolding daily in the camp. As a result, the fates of individual characters-such as businesswoman Fatima, who lives alone and wears short skirts in defiance of convention, or teacher Fatih, who leaves the camp to seek asylum in the United Kingdom and suffers the dehumanizing indignity of X-rays and fingerprinting at Heathrow-matter to the reader.

Rather than the meta-narratives of homeland, al Nakba, and the right of return that have emerged in previous research into Palestinian experience, the central chapters of this book focus on pragmatic responses to the challenges of camp life. These are the quotidian issues of immediate and pressing concern, what Ulrich Beck (1994) calls "sub
(C) Author(s), 2016. This open-access work is licensed under a Creative Commons Attribution-NonCommercial 4.0 International license.
Cette oeuvre en libre accès fait l'object d'une licence Creative Commons Attribution-NonCommercial 4.0 International. 
politics." However, Allan is at pains to illustrate the ways in which Shatilla is home for those who live in it-for many the only home they have known-and should not be portrayed as limbo or a place of transition. For this reason, the book contributes to debates on the meaning of home, as well as those on the nature of belonging and identity.

The chapter "Economic Subjectivity and Everyday Solidarities" details how refugees tackle economic hardship now that the village committees, which once provided assistance, have dwindled. In some cases, this amounts to "reluctant reciprocity" as the obligations of kinship are tested. At other times, neighbours provide a safety net, whilst the more recent development of savings associations allow women, in particular, to mobilize resources. Chapter 3 outlines the widespread practice of "stealing power" as refugees tap into electricity supplies from outside Shatila. Allan sees the refugees as "pragmatic opportunists," as they respond to their historic marginalization by the Lebanese government by asserting their right to essential resources. This brings to mind Peter Loizos's suggestion that refugees often prove themselves to be adept "social capitalists," producing social capital out of the disruption of exile. ${ }^{2}$

"Dream Talk, Futurity, and Hope" is an innovative chapter that explores the role dreams play in the lives of camp residents, especially women, referring to the collective practice of recounting and interpreting dreams as a socially embedded ritual. Allan is aware that dreams are seen as "murky" and "unverifiable" and, therefore, usually ignored in research. Indeed, she confesses to initially dismissing them herself. However, Katherine Ewing's (1994) ${ }^{3}$ criticism of the rational skepticism that lies at the heart of anthropology led her to reassess dream talk as another form of pragmatism - a "pragmatics of hope" that allowed the refugees to root themselves in futurity. This suspicion of irrationality is mirrored by the suspicion of narratives as a focus for forced migration research, due to their slippery and subjective nature (Taylor 20134). Yet Allan's book makes a solid case for using narrative to gain a more nuanced understanding of the lived experience of exile.

In "Futures Elsewhere," Allan confronts the uncomfortable truth that, for many in Shatila, emigration is replacing return as an aspiration. A striking image of the frustration felt by unemployed young men is seen in their collective activity of pigeon flying on the rooftops, as they discuss the possibility of emigration, representing both metaphorical and actual escape. Allan sees their "emigration talk" as dream talk's counterpart, allowing them to imagine what lies beyond the camp. Detailing the perilous attempts of some refugees to get to Europe, she weighs up the cost of emigration for the individual and for those they leave behind, but recognizes emigration as one of the few ways of regaining agency.

Allan makes no claims for scientific detachment and it is evident that her subject matters a great deal to her. Refugees of the Revolution is as much about the process of conducting "activist research" and the challenges of showing solidarity whilst engaging in an academic endeavour, as it is about the realities under investigation. Indeed, it is her fear that by privileging the narratives of "national truths" in constructing the archive, she was "implicated in the structural forgetting of other, less usable pasts" (7), that precipitated her switch from an ideological to a phenomenological lens.

As a result, the book raises some uncomfortable questions for those of us engaged in forced migration research who hope that our work will challenge injustice and hostile discourses. Allan forces us to examine to what extent our interventions reproduce prevailing narratives, rather than allowing diverse voices to emerge. She recounts one exchange with a young man, tired of foreigners arriving at the camp to do research: "It's like a thrill for them. We cry and they profit from our tears, but things stay the same for us. The electricity is still shit, we have no rights" (64). Allan is aware that she has adopted a risky strategy, which could result in her work being used by those who seek to undermine the right of Palestinians to return and to self-determination. However, the reality is that refugee experience and refugee identity are multiple, fluid, and contradictory and cannot be tied to a singular political or national narrative.

Helen Taylor is a visiting research fellow at the Centre for Research on Migration, Refugees and Belonging, University of East London. The author may be contacted at h.m.taylor@virginmedia.com.

\section{Notes}

1 Ulrich Beck, "The Reinvention of Politics: Towards a Reflexive Theory of Modernization," in Reflexive Modernization: Politics, Tradition and Aesthetics in the Modern Social Order, ed. Ulrich Beck, Anthony Giddens, and Scott Lash, 1-55 (Stanford, CA: Stanford University Press, 1994).

2 Peter Loizos, "Are Refugees Social Capitalists?" in Social Capital: Critical Perspectives, ed. Stephen Baron, John Field, and Tom Schuller, 124-41 (Oxford: Oxford University Press, 2000).

3 Katherine P. Ewing, "Dreams from a Saint: Anthropological Atheism and the Temptation to Believe," American Anthropologist 96, no. 3 (1994): 571-83.

4 Helen Taylor, "You Don't Believe Me? Truth and Testimony in Cypriot Refugee Narratives," in Evidence and Testimony in Life Story Narratives, ed. Nanci Adler and Selma Leydesdorff, 37-53 (New Brunswick, NJ: Transaction, 2013).
(C) Author(s), 2016. This open-access work is licensed under a Creative Commons Attribution-NonCommercial 4.0 International license.
Cette oeuvre en libre accès fait l'object d'une licence Creative Commons Attribution-NonCommercial 4.0 International. 


\title{
The Agendas of Tibetan Refugees: Survival Strategies of a Government-in-Exile in a World of Transnational Organizations
}

\author{
n \\ Thomas Kauffmann \\ New York: Berghahn, 2015, pp. 226
}

$\mathrm{I}$ $\mathrm{n}$ The Agendas of Tibetan Refugees: Survival Strategies of a Government-in-Exile in a World of Transnational Organizations, Dr. Thomas Kaufmann seeks to understand "How, after more than fifty years of exile, are the Tibetan refugees still able to attract such substantial assistance from Western governments, NGOs, other organizations and individuals, unlike other populations of refugees who are largely or totally forgotten?" (2).

Dr. Kaufmann has carried out a praiseworthy examination of the exile Tibetan community in India. To respond to his research question, over the course of seven chapters, he explains the political history, religion, culture, and current socioeconomic conditions of Tibetans living in exile in India. Briefly, in chapter 1 , he compiles historical information spanning more than five decades and describes the settlement and rehabilitation of the Tibetan refugee community in different parts of India. The second chapter highlights the establishment as well as the evolution of the Central Tibetan Administration (СTA) as a legitimate guiding agency of the Tibetan people in exile. In chapters 3 and 4 he presents the key elements of his work that answers his research question. He underlines the CTA's political and religious agendas that come together to attract international assistance. He then analyzes the reception of these two agendas in the West in chapter 5 . In chapter 6 , he examines the model of the donorrecipient relationship between the Tibetan refugee community spearheaded by the CTA and the West. He concludes that the Tibetan model of relationships with transnational organizations, although extremely successful for this group, is a difficult one for other groups to replicate (150). In his last chapter, he aptly introduces challenges that this refugee community is facing in light of migration to Western nations since the onset of the "American Lottery" that began in the 1990s, and transformation that this community is facing due to decreasing fertility rates, older adults left behind in settlements, social inequalities, etc.

The central argument that Dr. Kaufmann develops throughout the book is that the Tibetan refugee community has been so successful in attracting financial assistance because it has developed bilateral relationships with international donors, where both parties work as equals. That is, the refugee communities have something to give back to the international donors in exchange for the assistance received. He underpins this mutually supportive relationship using two agendas, religious and political, which the CTA has set, and which the Tibetan diaspora also follows. The main idea behind both agendas is that the Tibetan refugee community has transformed itself as the ideal receiver by fitting into an image that stands for universal values that are widely appreciated by Western donors. Their diaspora is portrayed as one of a democratic, environmentalist, and non-violent community, turning the Tibetan cause into a just one (chapter 3). Moreover, Dr. Kaufmann asserts that Tibetan Buddhism has been essentialized and commodified, and a mutually beneficial relationship has been conceived on the traditional "mchog-yon," or teacher-student relationship. Thus the teacher-student relationship is built with the Western donors, where the teacher gives spiritual teaching and, in return, the students fulfill the teacher's material needs (chapter 4). In sum, these identifiable Western democratic principles combined with the promotion of Tibetan Buddhist culture as something that is worth saving not only for the Tibetans but for the entire world, allows donors to eagerly and willingly assist the Tibetan cause and thereby the Tibetan refugees (chapter 5).

The book thus contributes a good deal to both Tibetan studies and refugee and migration studies. That said, we have identified some weaknesses in the book. One set of concerns relates to the study sample. We believe that this book would have benefited from more transparency about who was interviewed.

While Dr. Kaufmann does clarify in the introduction that his study is based on "more than 150 structured or semi-structured Interviews" (8), the reader learns little else about them. We deduce that most of the interviewees were ordinary Tibetan refugees who were not CTA employees. As only (limited) interviews were carried out with CTA members, it is puzzling why the workings of average Tibetan refugees are interpreted as CTA strategies. Furthermore, the analysis relies heavily on document review and liberal interpretation of the Dalai Lama's presence on the international stage (chapter 4) to support claims about the CTA's religious and political agendas. We think Dr. Kaufmann's conclusions would be more valid if he had discussed these findings
(C) Author(s), 2016. This open-access work is licensed under a Creative Commons Attribution-NonCommercial 4.0 International license.
Cette oeuvre en libre accès fait l'object d'une licence Creative Commons Attribution-NonCommercial 4.0 International. 
with key individuals from CTA's Department of Religion and Culture as well as the Department of Information and International Relation, and then reported back to the reader the outcome of those consultations.

Another concern related to the study sample stems from repeated use of the term "the Tibetans" $(76,78,79)$. The frequent deployment of "the Tibetans" seems to encompass all Tibetans living in exile (in India and elsewhere). A place where more nuance would also be useful can be seen (95 and elsewhere) where Dr. Kaufmann reports that "Tibetans tend to represent Western societies as spiritually weak and, as such, willing to receive religious teachings from Tibetans." With little demographic detail on who is included in his study, this, unfortunately, conveys the sense that Tibetans are of the same opinion or act in the same way.

More information on sample selection and demographics of those interviewed, and even greater use of direct quotes from his interviews would help the reader to contextualize provocative claims. With respect to provocative claims, here is another example: Dr. Kaufmann notes ( 76 and elsewhere) that Tibetans tend to present themselves as impoverished (when they are not) to gain sponsors. We acknowledge that many Tibetan children, monks, older adults with no children, and even families are generously supported by Western donors. One dimension of this set of relationships that Dr. Kaufmann glosses over (that we know from our own research) is that some sponsors choose to continue the relationship with their assigned person even after that person's or family's situation has improved. Such circumstances might lead to the perception that well-off families still unfairly receive financial support. What is not acknowledged is that there are more Tibetan children and older parents who are supported by their family members. They do not rely on sponsors and may even refuse to do so.

Overall, more circumspection regarding study conclusions, and further consideration of alternative explanations contradicting the central claims the author makes would strengthen this book. For instance, the key point in Dr. Kaufmann's depiction of the Tibetan refugees' (and thereby the CTA's) political and religious agenda is that these processes have been manufactured by the actors to fit with popular Western notions (see chapters 3 and 4 ). The discussion that this could also be the result of natural processes of change, adaptation, and survival is missing.

Finally, we thoroughly applaud Dr. Kaufmann for his work and think, despite his claim to the contrary, that the Tibetan success model speaks to experiences of other diasporic communities, e.g. outmigration, identity crisis, and the need to persevere politically, religiously, and as an ethnic group. Thus, we see less exceptionalism and more overlap between the Tibetan experience and that of other populations than Dr. Kaufmann, perhaps, allows.

Tenzin Wangmo is a senior researcher at the Institute for Biomedical Ethics, University of Basel. She may be contacted at tenzin.wangmo@unibas.ch.

Tenzin Sherab is a PhD student at the University of Fribourg. He may be contacted at sherab.tenzin@unifr.ch.

\title{
Forced Migration, Reconciliation and Justice
}

\author{
$\sim$ \\ Edited by Megan Bradley \\ Montreal and Kingston: McGill-Queen’s University Press, 2015, pp. 448
}

$\mathrm{C}$ et ouvrage dirigé par Megan Bradley est publié à un moment où le nombre de personnes déplacées en raison de conflits atteint un niveau sans précédent dans le monde. La réflexion sur des solutions durables à la migration forcée est non seulement d'actualité, mais aussi d'une grande utilité. Ceci d'autant plus que l'accent est mis sur l'importance de la justice et la réconciliation dans ce processus.

L'ouvrage regroupe des contributions d'auteurs de disciplines différentes et d'expériences professionnelles variées qui explorent des concepts et théories, ainsi que des situations locales et nationales. Des méthodes de recherche diverses y sont adoptées, telles que des entrevues, la recherche ethnographique, et l'analyse historique, juridique et philosophique. Les quatorze chapitres du livre sont structurés autour de trois parties examinant les liens entre les notions de déplacement forcé, la justice et la réconciliation, les expériences de la diaspora et des communautés hôtes, et des solutions à la migration forcée. Une attention particulière est portée sur des questions qui, jusqu'à présent, n'ont pas fait l'objet d'étude systématique. Tel est le cas des pratiques religieuses, de l'histoire orale, des interactions sociales quotidiennes comme autant de moyens de réconciliation entre les communautés affectées par le déplacement forcé.
(C) Author(s), 2016. This open-access work is licensed under a Creative Commons Attribution-NonCommercial 4.0 International license.
Cette oeuvre en libre accès fait l'object d'une licence Creative Commons Attribution-NonCommercial 4.0 International. 
La première partie compare et contraste divers théories et mécanismes de justice et propose une analyse critique de leur mise en ouvre. Dans son examen des initiatives internationales récentes relatives à la consolidation de la paix, et notamment de la Commission de Consolidation de la Paix de l'Organisation des Nations Unies (ONU), James Milner note que ces initiatives privilégient la prévention de la violence comme solution durable, au détriment de la résolution des causes profondes des conflits. Or une telle approche, selon l'auteur, n'est pas propice à la réconciliation. Partant du constat que la présence prolongée des réfugiés dans les pays voisins peut affecter le processus de paix, Milner suggère que les questions relatives aux réfugiés soient intégrées plus systématiquement dans les réponses aux conflits de longue durée. Anneke Smith porte un regard tout aussi critique aux Principes sur la restitution $d u$ logement et des biens des réfugiés et des personnes déplacées adoptés par l'onu en 2005. L'apport de ces principes au processus de réconciliation serait limité pour plusieurs raisons, y compris la priorité qu'ils accordent à la justice corrective, c'est-à-dire la restitution en espèce et le retour des personnes déplacées à leurs logements. Cette solution s'est avérée inefficace, d'après l'auteure, car elle est ni adaptée aux besoins des populations, ni ne répond aux divers défis liés à la justice transitionnelle. Smith note que dans certains pays, les mécanismes internationaux de restitution de biens ont intensifié les tensions sur le terrain. De même, l'éviction forcée de nouveaux occupants de logements après le conflit serait de nature à créer de nouvelles injustices. Cette analyse est partagée par Roger Duthie qui examine la contribution de la justice transitionnelle à la réintégration des réfugiés et aux efforts de réconciliation. Duthie remarque que les personnes déplacées qui rentrent chez elles après le conflit rencontrent des difficultés considérables, telles que la discrimination et l'hostilité, ce qui aggrave le risque de marginalisation psychologique et socioéconomique des individus déplacés. La reconnaissance et la compensation des abus des droits humains causés par les déplacements seraient essentielles à la réintégration. Le soutien à la société civile, les poursuites judiciaires et les sanctions contre des personnes responsables des exactions, et la réforme de la police et de l'armée feraient tous partie des pas positifs de la part de l'état à cet égard. Ces initiatives permettraient la création d'une nouvelle relation entre l'état et les personnes qui retournent chez elles, ainsi que la reconnaissance de celles-ci comme des citoyens à part entière.

La seconde partie de l'ouvrage regroupe des contributions examinant les expériences de la diaspora et des communautés hôtes dans différents pays qui ont été affectés par des déplacements forcés suite à des conflits. Mateja Celestina explore la situation des personnes déplacées en Colombie qui, en vertu d'un programme gouvernemental, ont été installées dans un hameau et devaient y habiter douze ans avant de gagner les droits de propriété officiels. L'auteure montre que la coexistence entre la population locale et les nouveaux arrivants est difficile en raison des différences culturelles, des conflits de pouvoir, et de la peur et la stigmatisation de l'«autre»; le tout étant exacerbé par les expériences traumatisantes du conflit. Thien-Huong T. Ninh, quant à elle, pose un regard critique sur le rôle de l'Église catholique qui aurait approfondi les divisions existantes entre la diaspora vietnamienne catholique et le peuple khmer au Cambodge. Lauteure explique comment les missionnaires français qui sont retournés au Cambodge après le conflit ont privilégié répandre le catholicisme parmi la population khmer et ont négligé, voire discriminé, la minorité vietnamienne. Le chapitre examine aussi le pouvoir de croyance religieuse dans la réintégration des populations affectées par le déplacement forcé. Comment réconcilier la communauté rwandaise à Montréal et parler objectivement de leur histoire communet? Lisa Ndejuru répond à cette question en analysant le rôle de la narration (storytelling) dans le processus de réconciliation. La performance d'histoire orale à travers les techniques de théâtre playback offrirait un espace privilégié où les participants peuvent dialoguer et exprimer leur vulnérabilité de manière constructive. Ndejuru estime que la réconciliation nécessite une discussion ouverte des expériences personnelles relatives au conflit et au déracinement.

Des solutions théoriques et pratiques au déplacement sont discutées plus en détail dans la dernière partie du livre. Les contributions conceptualisent le déplacement comme, avant tout, un problème de droits humains et de dignité humaine. Ainsi, Roberto Vidal Lopez critique l'usage rhétorique de la justice transitionnelle en Colombie. Ce discours serait instrumentalisé dans le but de rassurer les bailleurs de fonds internationaux. Huma Haider souligne qu'en Bosnie-Herzégovine, la méfiance entre les communautés est exacerbée par le taux élevé de chômage et les discriminations contre les minorités déplacées. Ceux-ci constitueraient des obstacles majeurs à la consolidation de la paix. Le cas de ce pays illustre que la repossession des propriétés et la reconstruction ne sont pas suffisantes pour assurer une réintégration socioéconomique durable des personnes déplacées. Des constats similaires sont faits par Ayse Betül Çelik qui estime que la reconstruction des logements et la revitalisation économique ne sauraient à elles seules garantir la réconciliation qui nécessite une solution politique aux causes profondes des déplacements forcés en Turquie. L'auteure note que le déplacement a nourri la pauvreté urbaine et que le programme gouvernemental de compensation n'a pas réussi à promouvoir la réconciliation entre le gouvernement et la société turque. Une des raisons
(C) Author(s), 2016. This open-access work is licensed under a Creative Commons Attribution-NonCommercial 4.0 International license.
Cette oeuvre en libre accès fait l'object d'une licence Creative Commons Attribution-NonCommercial 4.0 International. 
de cet échec serait liée au fait que le gouvernement et les organisations non-gouvernementales ont une conception et un discours diamétralement opposés de la nature du conflit au cour du déplacement. Cela complique la mise en œuvre de solutions comme la reconnaissance gouvernementale du tort causé à la minorité kurde, et l'établissement des institutions étatiques plus égalitaires. Des problèmes similaires sont constatés au niveau des programmes concernant les réfugiés palestiniens. Michael Molloy, John Bell, Nicole Waintraub et Ian B. Anderson remarquent que la compensation et la réinstallation doivent être complétées par une reconnaissance morale des torts et des abus commis de part et d'autre. Nancy Maroun examine le cas du Liban où un tiers de la population a été déplacé entre 1975-1990 et 75\% de cette population vit sous le seuil de pauvreté. L'auteure a suivi les travaux d'une commission bi-ethnique et bi-religieuse établie dans un des villages choisis dans le cadre de projets-pilotes de réconciliation. Ses conclusions rejoignent celles des contributeurs précédents: le projet-pilote aurait échoué en raison des jeux de pouvoirs, de l'hostilité envers la minorité chrétienne, et de l'absence d'égalité qui auraient mené à la marginalisation de la population déplacée.

Plusieurs chapitres mettent en lumière les bonnes pratiques dans des pays ayant vécu des déplacements forcés. Celles-ci incluent des écoles mixtes enseignant un curriculum commun, des projets d'agriculture et des activités sportives qui réunissent des personnes déplacées, la communauté hôte et des organismes de la société civile. Ces initiatives aideraient à la réconciliation à travers la socialisation et le dialogue, surtout parmi les jeunes. Les auteurs s'entendent sur le fait que les personnes déplacées doivent activement prendre part dans le processus de justice transitionnelle, tout comme la diaspora et les communautés hôtes. En outre, Paige Morrow et Jennifer Winstanley examinent le rôle du droit international pénal comme un outil de réconciliation. Le Statut de Rome qui définit le transfert forcé de population comme un crime contre l'humanité aurait le potentiel de briser le cycle d'impunité en permettant le jugement des responsables devant la Cour pénale internationale. Les auteurs examinent cette possibilité dans le cas du Kenya, tout en soulignant les défis et obstacles inhérents à un tel processus. De même, Mick Dumper conteste la thèse selon laquelle le droit au retour des réfugiés deviendrait caduc avec le temps et le changement des circonstances. Il estime que pour les Palestiniens qui ont été déplacés, la rupture avec le passé n’a jamais été complète et qu'il existe plusieurs options possibles pour la réconciliation. La restitution de propriétés, la compensation, et l'amélioration de la situation économique et du statut juridique des personnes déplacées en feraient partie. Ces solutions devraient être réalisées dans le respect des droits socioéconomiques et culturels des Israéliens.

Le chapitre de conclusion par Megan Bradley synthétise les contributions et ouvre de nouvelles pistes de réflexion sur les intersections entre la justice transitionnelle et la réconciliation. Il explore l'implication de celles-ci pour la recherche, les politiques et les pratiques relatives aux migrations forcées. La richesse de l'analyse et la diversité des pays et des méthodes qui y font l'objet d'études font de ce livre une source d'information précieuse. Les chapitres donnent un riche compte-rendu du contexte historique et des conditions sociopolitiques qui ont été au cœur des déplacements forcés. Ces explications permettent au lecteur de mieux saisir les enjeux liés au déracinement, à la consolidation de la paix et à la réconciliation dans ces pays. Elles permettent également d'identifier les problèmes communs, ainsi que des mécanismes et des stratégies collectives et individuelles de réconciliation et de réintégration. L'ouvrage s'adresse à un public large, y compris aux étudiants, aux chercheurs de diverses disciplines, aux praticiens locaux et internationaux, et à toute personne intéressée aux migrations forcées et à la justice. Il constitue sans conteste une contribution importante aux débats dans ce domaine.

Idil Atak est professeure adjointe au Département de Justice criminelle et Criminologie de l'Université Ryerson. Veuillez la contacter à l'adresse suivante: idil.atak@arts.ryerson.ca.

\title{
Creating New Futures: Settling Children and Youth from Refugee Backgrounds
}

\author{
$\infty$ \\ Edited by Mary Crock \\ Sydney: Federation, 2015, pp. 313
}

$\mathrm{T}$ This edited volume provides an overview of processes and conditions for children of refugee backgrounds resettling in Australia. The book is divided into three sections, and the structure of the book works well to educate readers on the global reach of UNHCR resettlement programs and current migration and resettlement trends in Australia.
(C) Author(s), 2016. This open-access work is licensed under a Creative Commons Attribution-NonCommercial 4.0 International license.
Cette oeuvre en libre accès fait l'object d'une licence Creative Commons Attribution-NonCommercial 4.0 International. 
Crock's introduction lays out an important Australian migration policy framework that distinguishes between the organized migration of refugees (offshore programs) and policies and programs directed at those who arrive without authorization seeking asylum (onshore programs).

Parts 1 and 2 are devoted primarily to resettlement policy in Australia, and while there is some redundancy when taken as a whole, they also bring home the central argument of Crock's analysis laid out in the introduction about the "Janus-faced" nature of Australian migration policy: that it is among the best in the world for those who come already designated as refugees, while often devastating for asylum seekers subjected to mandatory detention. Further, the authors refer to children "from refugee backgrounds," rather than using the more common phrasing, "refugee children" for those who have resettled in a third country. Being a refugee has informed and shaped their life, but it does not represent the totality of experience and may obscure the desire for a future orientation.

The major thematic areas of the volume include the benefits of resettlement as a durable solution and Australian policy towards refugees compared with asylum seekers. Part 3 of the volume comprises an array of topics that explore the ways in which Australia welcomes refugee youth. These chapters address health, mental health, education, and deaf children, as well as considering policy that provides youth with long-term protection.

Parts 1 and 2 underscore the minor and underutilized place of resettlement in the larger international response to refugee movement. In particular, Piper's chapter, "The Strategic Use of Resettlement," enumerates its core functions, emphasizing its protection role, and how resettlement operates as an expression of international solidarity and collaboration. Piper describes the resettlement gap, or the cases from the United Nations High Commissioner for Refugees (UNHCR) that exceed the ability or willingness of states to accept for permanent resettlement. Most states resettle a relatively small number of refugees. Thus, while the number of resettlement states has grown, this has not resulted in significant increases in the number of resettlement slots worldwide. She also discusses the uneasiness many at UNHCR have with third country resettlement that has resulted in it not being well supported as a durable solution.

Chapter 2, by Crock and Martin, outlines the visa classes for those who arrive already as declared refugees as part of organized migration programs (United Nations High Commissioner for Refugees and International Organization for Migration). Many recent changes have occurred that affect onshore migrants, or those who arrive via boat or plane, and who seek asylum once they arrive. Onshore migrants have received much negative public attention, and as a result, policy has been altered in reaction. Restricting access to permanent protection for migrants in these groups has been part of Australian policy since 2001 (58). Crock and Martin thus show how Australian law has created a twoclass system for migrants, some of whom receive generous entitlements, and others have very few rights at all.

It is not until chapter 5 that the focus tightens on refugee youth. Piper and Thom argue that although youth is a designated priority category, it is underused. Although youth are some of the most vulnerable refugees, unaccompanied minors are explicitly unwelcome by most states, with the exception of Australia, Canada, and the United States. Comparisons between the programs of these states illuminate challenges and potential solutions, particularly important when the United States has seen a massive uptick in the numbers of unaccompanied minors coming from Central America in recent years.

Chapter 6, by Gifford and Kenny, strives to define youth resettlement. The authors argue that most research on Australian youth from migrant backgrounds focuses on vulnerabilities, and not on how differences in settlement environments affect youth integration. They propose broadening indicators of success beyond the individual, to encompass community-level factors. Chapter 7 incorporates the voices of youth themselves and focuses on what is needed for successful resettlement. In chapter 8, Guerra, Quek, and Kenny discuss policies on unaccompanied humanitarian minors, making the case that they are extremely vulnerable and yet resilient, requiring particular support for successful resettlement.

Chapter 9, by Newman and Locarnini, provides an overview of mental health as it relates to refugee children, especially as it includes recent developments in mental health treatment and their efficacy for children and youth. In chapter 10, Preston-Thomas discusses common health issues and makes specific recommendations for improvements to the health system, including availability of low/no-cost care, ensured translation access, and training for providers in refugee health. She contrasts this system with the health care available to asylum seekers and makes a powerful argument for providing services to this population as well.

Chapter 11 considers experiences and services available to deaf children and youth in Australia. Willoughby shows that children from refugee backgrounds may have a higher incidence of hearing loss. Chapter 12, by Windle, considers the education offered refugee youth, including separate English-as-a-second-language schools for migrants for six months, that establish a basis of literacy. The final chapter by Rubenstein and Field discusses revisions to citizenship laws that foreclose the possibility of parents using children's status as a means to stay in the country. As a result,
(C) Author(s), 2016. This open-access work is licensed under a Creative Commons Attribution-NonCommercial 4.0 International license.
Cette oeuvre en libre accès fait l'object d'une licence Creative Commons Attribution-NonCommercial 4.0 International. 
citizenship decisions for children are decided solely by parental status, making it impossible for children of parents whose claims to permanent residency fail to have access to citizenship.

In sum, Crock's volume provides a comprehensive view of current and past migration policy and the effects on migrants to Australia. The book will interest scholars, researchers, and refugee service providers who wish to learn from successes and challenges of third country resettlement programs. The book provides lessons to U.S. scholars, in particular, in its cautions about the effects of mandatory detention of asylum seekers, which are important to consider, given the numbers of unaccompanied minors from Central America who have entered the United States in recent years, and changing policy regarding their reception.

Julia Meredith Hess is research assistant professor at the Department of Anthropology, University of New Mexico. The author maybecontacted at jmhess@salud.unm.edu. 
